Prepared in cooperation with the Alaska Department of Transportation and Public Facilities

\title{
Streambed Scour Evaluations and Conditions at Selected Bridge Sites in Alaska, 2013-15
}

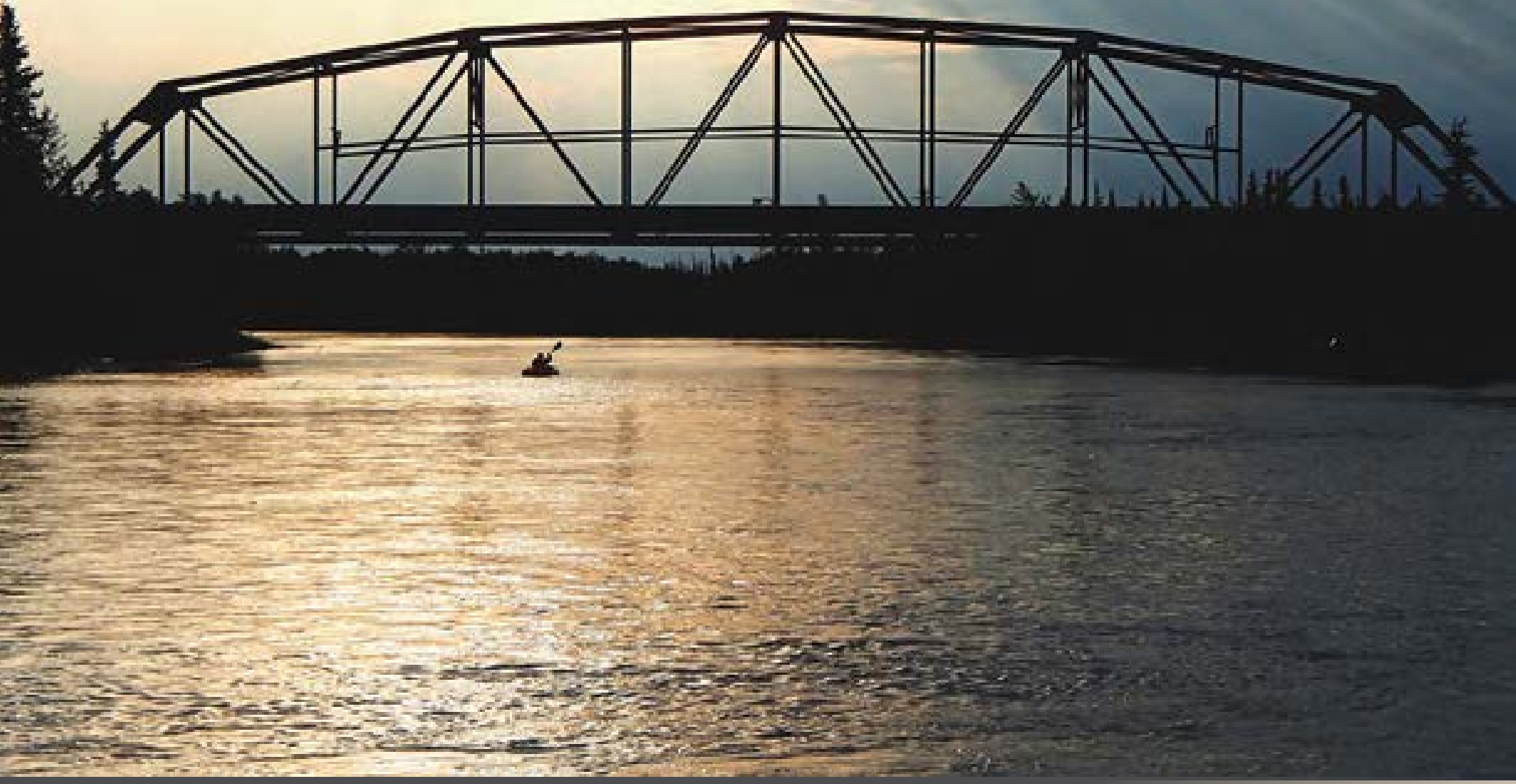

Scientific Investigations Report 2017-5149

U.S. Department of the Interior U.S. Geological Survey 
Cover: Photograph showing U.S. Geological Survey scientist measuring water depth and velocity with a kayak-mounted acoustic Doppler current profiler beneath the Chisana River Bridge near Northway, Alaska. Photograph by Robin A. Beebee, U.S. Geological Survey, June 15, 2015. 


\section{Streambed Scour Evaluations and Conditions at Selected Bridge Sites in Alaska, 2013-15}

By Robin A. Beebee, Karenth L. Dworsky, and Schyler J. Knopp

Prepared in cooperation with the Alaska Department of Transportation and Public Facilities

Scientific Investigations Report 2017-5149 


\title{
U.S. Department of the Interior \\ RYAN K. ZINKE, Secretary
}

\section{U.S. Geological Survey \\ William H. Werkheiser, Deputy Director \\ exercising the authority of the Director}

\author{
U.S. Geological Survey, Reston, Virginia: 2017
}

For more information on the USGS — the Federal source for science about the Earth, its natural and living resources, natural hazards, and the environment-visit https://www.usgs.gov or call 1-888-ASK-USGS.

For an overview of USGS information products, including maps, imagery, and publications, visit https://store.usgs.gov.

Any use of trade, firm, or product names is for descriptive purposes only and does not imply endorsement by the U.S. Government.

Although this information product, for the most part, is in the public domain, it also may contain copyrighted materials as noted in the text. Permission to reproduce copyrighted items must be secured from the copyright owner.

Suggested citation:

Beebee, R.A., Dworsky, K.L., and Knopp, S.J., 2017, Streambed scour evaluations and conditions at selected bridge sites in Alaska, 2013-15: U.S. Geological Survey Scientific Investigations Report 2017-5149, 67 p., https://doi.org/10.3133/sir20175149.

ISSN 2328-0328 (online) 


\section{Contents}

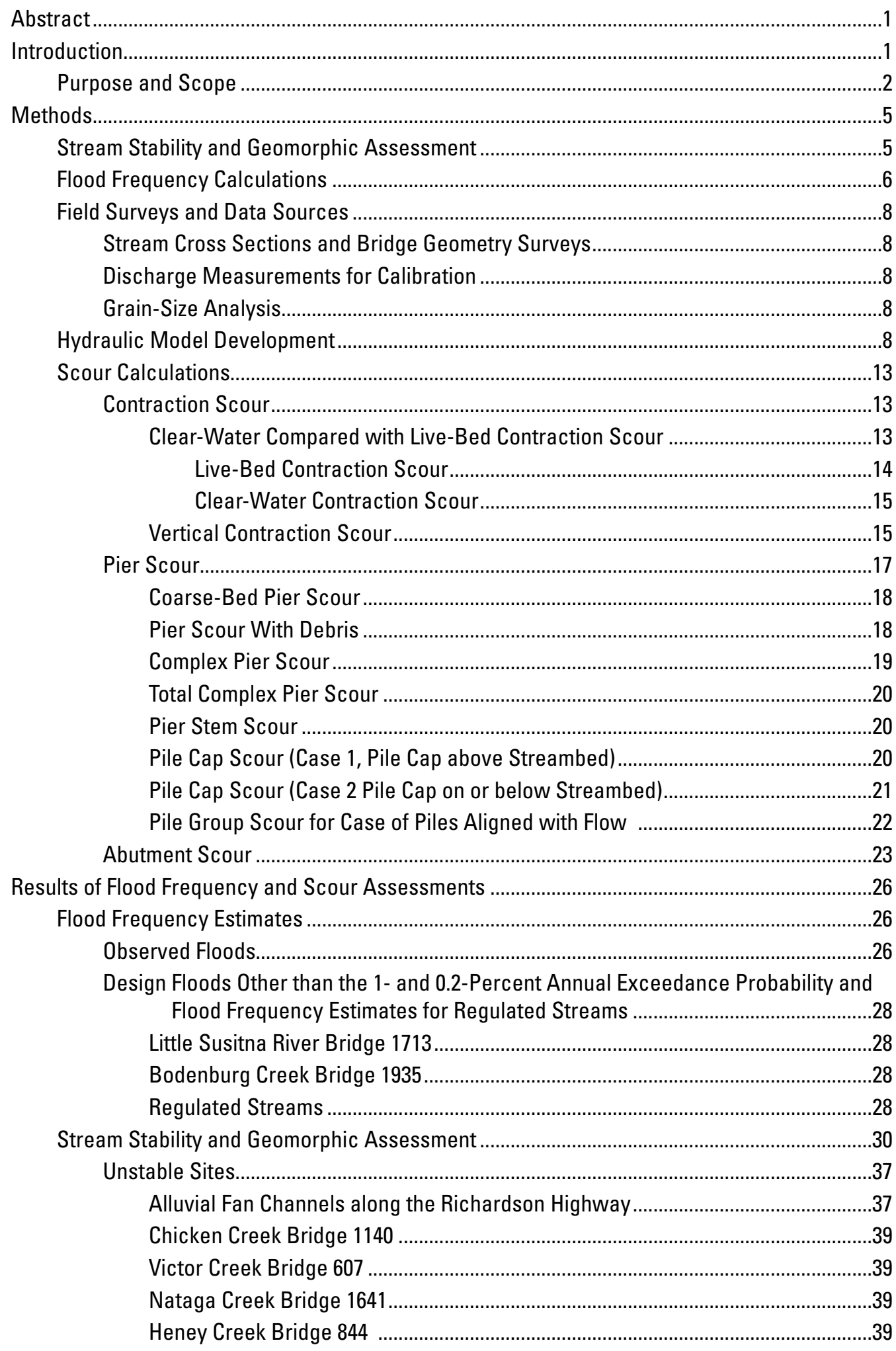




\section{Contents-Continued}

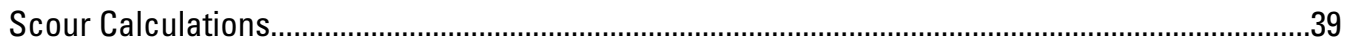

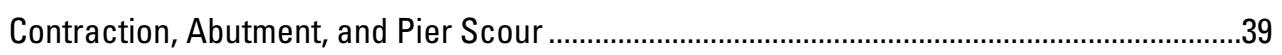

Bridges with High Scour Estimates ..............................................................................6

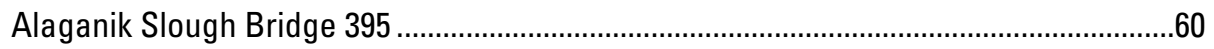

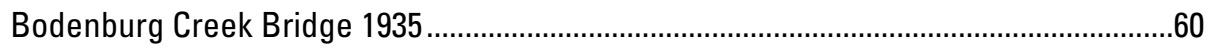

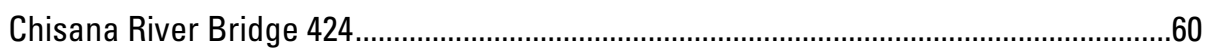

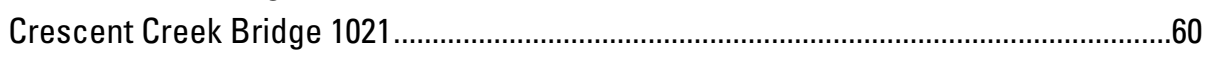

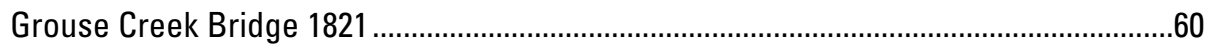

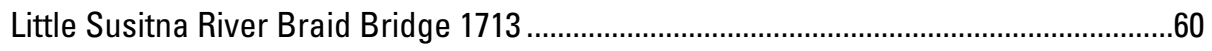

Logjam Creek Bridge 1717 ................................................................................. 61

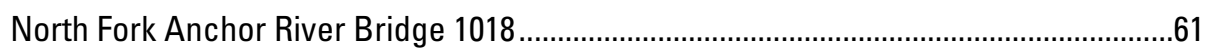

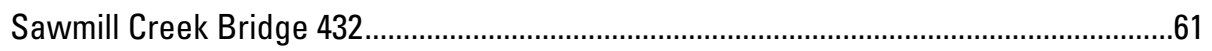

South Fork Anchor River Bridge 1199......................................................................61

Taiya River Bridge 309.......................................................................................61

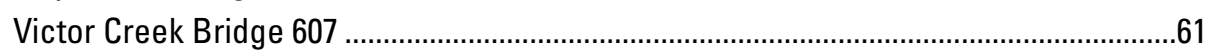

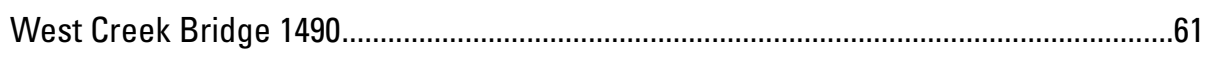

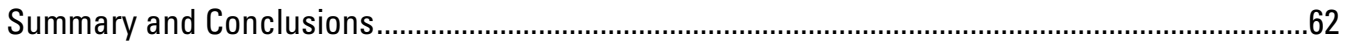

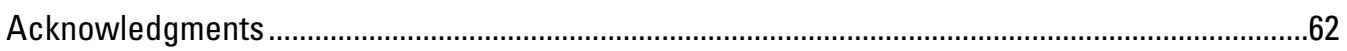

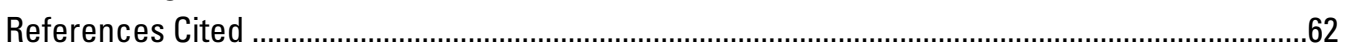

Appendix 1. Stream Stability Cross Sections ...............................................................................67

\section{Figures}

1. Diagram showing example of streambed scour around a bridge foundation...................2

2. Map showing locations of selected bridge sites in Alaska where scour was

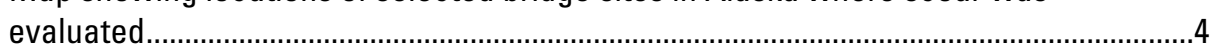

3. Diagram showing basic contraction scour conditions and variables defined in equations 1-3 .......................................................................................................14

4. Diagram showing example of vertical contraction scour and variables used to

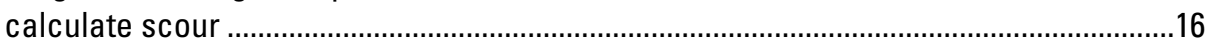

5. Diagram showing example of pier scour with variables used to calculate scour ..........17

6. Diagram showing example of complex pier-scour components and variables used

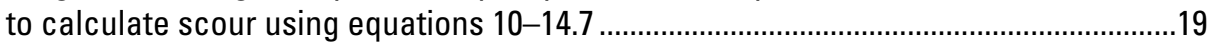

7. Diagrams showing examples of abutment scour plan and cross-section views ............23

8. Graphs showing amplification factor for live-bed abutment scour for wingwall

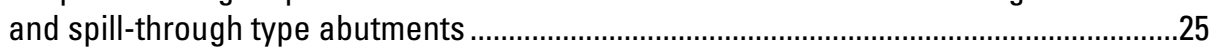

9. Graph showing flood frequency curves used to calculate the weighted 1- and 0.2-percent annual exceedance probability floods, with 5- and 95-percent confidence intervals for each analysis and measured peak flows at Tatalina River near Takotna, Alaska 


\section{Figures-Continued}

10. Map showing Bodenburg Creek overflow during floods in south-central Alaska, August 1971.

11. Graph showing flood frequency curves for the pre- and post-dam periods at Sawmill Creek near Sitka, Alaska...

12. Graph showing sounding-based stream stability at 52 river- and stream-spanning bridges in Alaska

13. Photographs showing "less stable" alluvial fans at Gunny Sack Creek Bridge 590 and Whistler Creek upstream of Bridge 587, Alaska.

\section{Tables}

1. Descriptions of selected bridge sites evaluated for scour in Alaska, 2013-15................3

2. Variables used in the flood frequency analysis for selected bridges in Alaska, 2013-15

3. Hydraulic modeling input data and sources from selected bridges in Alaska, 2013-15.

4. Discharges used to estimate scour at selected bridge sites in Alaska ...........................27

5. Stream stability as assessed using geomorphic evidence and repeat sounding records at selected bridge sites in Alaska...

6. Hydraulic variables and estimates of contraction scour for selected bridge sites in Alaska with no pressure flow.

7. Hydraulic variables and estimates of vertical contraction scour for selected bridge sites in Alaska with pressure flow

8. Estimated abutment scour and variables for selected bridge sites in Alaska .................44

9. Hydraulic variables and estimated pier scour at selected bridge sites in Alaska with simple piers.

10. Hydraulic variables and estimated pier scour at selected bridge sites in Alaska with complex piers

11. Hydraulic variables and estimated pier scour at selected bridges in Alaska with coarse beds and clear-water scour conditions.

12. Summary of estimated scour for selected bridge sites in Alaska, 2013-15 


\section{Conversion Factors}

U.S. customary units to International System of Units

\begin{tabular}{lcl}
\hline \multicolumn{1}{c}{ Multiply } & By & \multicolumn{1}{c}{ To obtain } \\
\hline inch (in.) & Length & \\
inch (in.) & 2.54 & centimeter $(\mathrm{cm})$ \\
foot (ft) & 25.4 & millimeter $(\mathrm{mm})$ \\
mile (mi) & 0.3048 & meter $(\mathrm{m})$ \\
\hline & 1.609 & kilometer $(\mathrm{km})$ \\
\hline square mile $\left(\mathrm{mi}^{2}\right)$ & Area & \\
square mile $\left(\mathrm{mi}^{2}\right)$ & 259.0 & hectare $($ ha) \\
& 2.590 & square kilometer $\left(\mathrm{km}^{2}\right)$ \\
\hline foot per second $(\mathrm{ft} / \mathrm{s})$ & Flow rate & \\
square foot per second $\left(\mathrm{ft}^{2} / \mathrm{s}\right)$ & 0.3048 & meter per second $(\mathrm{m} / \mathrm{s})$ \\
cubic foot per second $\left(\mathrm{ft}^{3} / \mathrm{s}\right)$ & 0.0929 & square meter per second $(\mathrm{m} 2 / \mathrm{s})$ \\
\hline & 0.02832 & cubic meter per second $\left(\mathrm{m}^{3} / \mathrm{s}\right)$ \\
\hline foot per square second $\left(\mathrm{ft} / \mathrm{s}^{2}\right)$ & Acceleration & \\
\hline
\end{tabular}

International System of Units to U.S. customary units

\begin{tabular}{lll}
\hline Multiply & By & To obtain \\
\hline & Length & \\
\hline millimeter $(\mathrm{mm})$ & 0.03937 & inch (in.) \\
\hline
\end{tabular}

Temperature in degrees Fahrenheit $\left({ }^{\circ} \mathrm{F}\right)$ may be converted to degrees Celsius $\left({ }^{\circ} \mathrm{C}\right)$ as

$$
{ }^{\circ} \mathrm{C}=\left({ }^{\circ} \mathrm{F}-32\right) / 1.8 \text {. }
$$

\section{Datums}

Vertical coordinate information is site specific and, in most cases, is referenced either to as-built elevations on bridge plans (if available) or to a reference mark with an assumed elevation of 100 feet established during the survey on or near the bridge deck. Other geographic data (for example, lidar) are adjusted to match the bridge datum, unless otherwise noted.

Horizontal coordinate information is referenced to the World Geodetic System of 1984 (WGS 84).

\section{Abbreviations}

\begin{tabular}{|c|c|}
\hline ADCP & acoustic Doppler current profiler \\
\hline ADOT\&PF & Alaska Department of Transportation and Public Facilities \\
\hline AEP & annual exceedance probability \\
\hline EMA & Expected Moments Algorithm \\
\hline FERC & Federal Energy Regulatory Commission \\
\hline HEC-RAS & $\begin{array}{l}\text { Hydrologic Engineering Center River Analysis System (U.S. Army Corps of } \\
\text { Engineers) }\end{array}$ \\
\hline IfSAR & Interferometric synthetic aperture radar \\
\hline lidar & light detection and ranging \\
\hline USGS & U.S. Geological Survey \\
\hline
\end{tabular}




\title{
Streambed Scour Evaluations and Conditions at Selected Bridge Sites in Alaska, 2013-15
}

\author{
By Robin A. Beebee, Karenth L. Dworsky, and Schyler J. Knopp
}

\begin{abstract}
Streambed scour potential was evaluated at 52 river- and stream-spanning bridges in Alaska that lack a quantitative scour analysis or have unknown foundation details. All sites were evaluated for stream stability and long-term scour potential. Contraction scour and abutment scour were calculated for 52 bridges, and pier scour was calculated for 11 bridges that had piers. Vertical contraction (pressure flow) scour was calculated for sites where the modeled water surface was higher than the superstructure of the bridge. In most cases, hydraulic models of the 1- and 0.2-percent annual exceedance probability floods (also known as the 100- and 500-year floods, respectively) were used to derive hydraulic variables for the scour calculations. Alternate flood values were used in scour calculations for sites where smaller floods overtopped a bridge or where standard flood-frequency estimation techniques did not apply. Scour also was calculated for large recorded floods at 13 sites.

Channel instability at 11 sites was related to human activities (in-channel mining, dredging, and channel relocation). Eight of the dredged sites are located on active unstable alluvial fans and were graded to protect infrastructure. The trend toward aggradation during major floods at these sites reduces confidence in scour estimates.

Vertical contraction and pressure flow occurred during the 0.2-percent or smaller annual exceedance probability floods at eight sites. Contraction scour exceeded 5 feet (ft) at four sites, and total scour at piers (pier scour plus contraction scour) exceeded $5 \mathrm{ft}$ at four sites. Debris accumulation increased calculated pier scour at six sites by an average of 2.4 $\mathrm{ft}$. Total scour at abutments exceeded $5 \mathrm{ft}$ at 10 sites. Scour estimates seemed excessive at two piers where equations did not account
\end{abstract}

for channel armoring, and at four abutments where failure of the embankment and attendant channel widening would reduce scour.

\section{Introduction}

Bridge foundations, including abutments and piers, depend on being embedded a certain depth into the streambed for stability. Scour refers to the removal of streambed material beneath a bridge, generally by hydraulic stresses exerted on the streambed and bridge foundation during floods (fig. 1). Scour has the potential to damage bridges by undermining or destabilizing the bridge foundation and is the leading cause of bridge failure in the United States (Lagasse and others, 2012). In 1998, the Federal Highway Administration established a policy that all bridges be assessed for scour potential. It is standard engineering practice for bridge engineers to evaluate scour potential during the design process and to plan foundations accordingly. However, a national inventory of bridges and engineering plans indicated that numerous bridges in Alaska lacked quantitative scour assessments and (or) detailed foundation information needed to categorize the vulnerability of the structure to damage or failure by scour. Some of these bridges are old and plans may have been lost, some were emergency replacements after floods, and others were intended to be temporary structures. A hydraulic assessment of streambed scour potential is needed in every case. The Alaska Department of Transportation and Public Facilities (ADOT\&PF) intends to use these assessments to prioritize sites with a high potential for streambed scour for further investigation. 


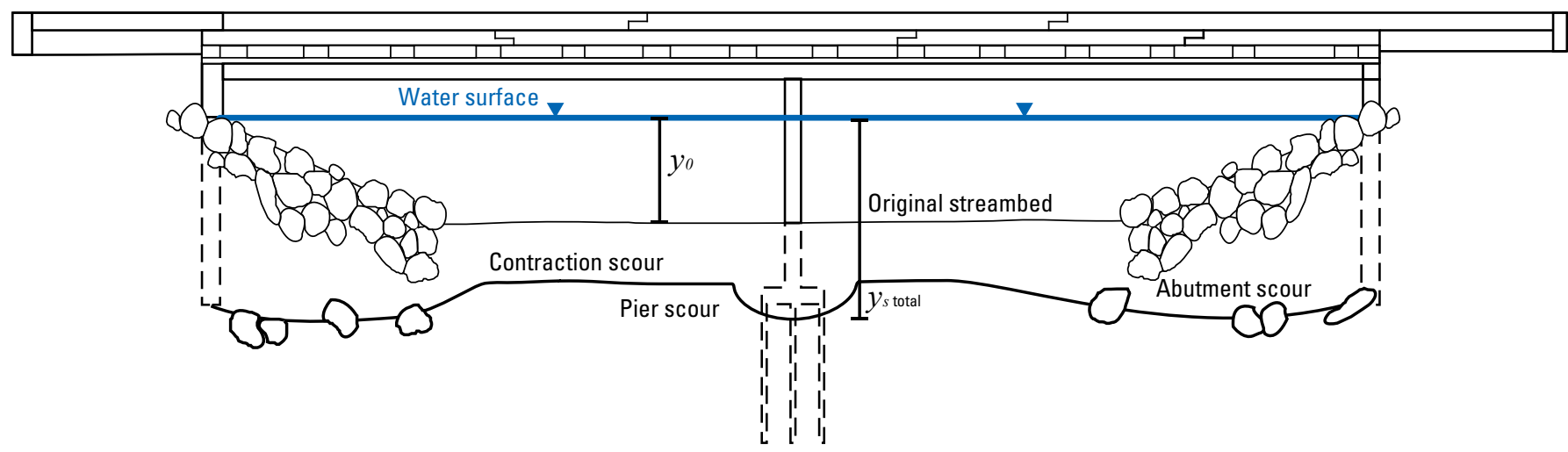

Figure 1. Example of streambed scour around a bridge foundation.

Scour is primarily a symptom of an undersized or misaligned bridge, and its severity depends on the extent to which a bridge is blocking natural flow paths during floods. Other factors include the mobility of streambed material, the magnitude of flood events that occur in the reach, embankment stability, debris accumulation, channel stability, and upstream sediment supply. Standard engineering methods do not account for every riverine process that influences scour (Conaway, 2007).

\section{Purpose and Scope}

This report describes methods and results of scour investigations at 52 bridges with unknown foundations or incomplete scour assessments and addresses geomorphic and human factors that may influence scour but are not accounted for in the calculations. Hydraulic models were developed and scour calculations were completed for all bridges following the guidance of Arneson and others (2012). Types of scour addressed include channel-wide scour caused by contraction of the channel width through the bridge, local scour around piers and abutments, and larger-scale instability of the river reach.

The U.S. Geological Survey (USGS) has been studying scour at bridges in Alaska since 1964 (Norman, 1975). In cooperation with the ADOT\&PF, the USGS began a phased process in 1994 to provide hydraulic assessments of scour for bridges throughout Alaska (Heinrichs and others, 2001; Conaway, 2004; Conaway and Schauer, 2012; Beebee and Schauer, 2015). This study follows the approach of Beebee and Schauer (2015), using one-dimensional models and site-specific information, but includes updated methods for addressing unsteady flow, channel stability, flood frequency, abutment scour, and scour at piers in coarse-bedded streams.

The 52 sites selected by ADOT\&PF for scour assessments are located throughout Alaska in different geographic and hydrologic settings (table 1 and fig. 2). 
Table 1. Descriptions of selected bridge sites evaluated for scour in Alaska, 2013-15.

[WGS 84: World Geodetic System of 1984. NBI Code 113: The National Bridge Scour Critical code for bridge. T, bridge over tidal waterways with no scour analysis; $\mathrm{U}$, bridge with unknown foundations and no scour analysis; 6 , bridge with no scour analyses]

\begin{tabular}{|c|c|c|c|c|c|c|}
\hline $\begin{array}{c}\text { Bridge } \\
\text { No. } \\
\text { (fig. 2) }\end{array}$ & Stream name & $\begin{array}{l}\text { Latitude } \\
\text { (WGS 84) }\end{array}$ & $\begin{array}{l}\text { Longitude } \\
\text { (WGS 84) }\end{array}$ & $\begin{array}{l}\text { Year } \\
\text { built }\end{array}$ & $\begin{array}{c}\text { NBI } \\
\text { Code } 113\end{array}$ & $\begin{array}{c}\text { Bridge length } \\
\text { (feet) }\end{array}$ \\
\hline 395 & Alaganik Slough & $60^{\circ} 26^{\prime} 48^{\prime \prime} \mathrm{N}$ & $145^{\circ} 12^{\prime} 46^{\prime \prime} \mathrm{W}$ & 1987 & $\mathrm{~T}$ & 160 \\
\hline 433 & Barabara Creek & $59^{\circ} 28^{\prime} 42^{\prime \prime} \mathrm{N}$ & $151^{\circ} 38^{\prime} 42^{\prime \prime} \mathrm{W}$ & 1968 & $\mathrm{U}$ & 72 \\
\hline 2213 & Barney Creek & $55^{\circ} 09^{\prime} 00^{\prime \prime} \mathrm{N}$ & $162^{\circ} 25^{\prime} 48^{\prime \prime} \mathrm{W}$ & 2006 & $\mathrm{U}$ & 100 \\
\hline 1935 & Bodenburg Creek & $61^{\circ} 33^{\prime} 30^{\prime \prime} \mathrm{N}$ & $149^{\circ} 02^{\prime} 12^{\prime \prime} \mathrm{W}$ & 2002 & $\mathrm{U}$ & 39 \\
\hline 588 & Boulder Creek & $63^{\circ} 26^{\prime} 48^{\prime \prime} \mathrm{N}$ & $145^{\circ} 51^{\prime} 06^{\prime \prime} \mathrm{W}$ & 1954 & 6 & 37 \\
\hline 645 & Campbell at Old Seward & $61^{\circ} 10^{\prime} 12^{\prime \prime} \mathrm{N}$ & $149^{\circ} 52^{\prime} 18^{\prime \prime} \mathrm{W}$ & 1982 & 6 & 81 \\
\hline 1140 & Chicken Creek & $64^{\circ} 04^{\prime} 48^{\prime \prime} \mathrm{N}$ & $141^{\circ} 57^{\prime} 30^{\prime \prime} \mathrm{W}$ & 1962 & 6 & 26 \\
\hline 424 & Chisana River & $63^{\circ} 00^{\prime} 24^{\prime \prime} \mathrm{N}$ & $141^{\circ} 48^{\prime} 12^{\prime \prime} \mathrm{W}$ & 1944 & 6 & 252 \\
\hline 2282 & Coffman Creek & $55^{\circ} 59^{\prime} 31^{\prime \prime} \mathrm{N}$ & $132^{\circ} 52^{\prime} 19^{\prime \prime} \mathrm{W}$ & 2006 & 6 & 80 \\
\hline 674 & Cooper Creek & $60^{\circ} 32^{\prime} 12^{\prime \prime} \mathrm{N}$ & $150^{\circ} 45^{\prime} 18^{\prime \prime} \mathrm{W}$ & 1955 & 6 & 68 \\
\hline 1021 & Crescent Creek & $60^{\circ} 29^{\prime} 48^{\prime \prime} \mathrm{N}$ & $149^{\circ} 40^{\prime} 42^{\prime \prime} \mathrm{W}$ & 1959 & $\mathrm{U}$ & 56 \\
\hline 2283 & Dog Creek & $56^{\circ} 00^{\prime} 08^{\prime \prime} \mathrm{N}$ & $132^{\circ} 49^{\prime} 34^{\prime \prime} \mathrm{W}$ & 2006 & 6 & 38 \\
\hline 2279 & Dog Creek Tidal & $56^{\circ} 00^{\prime} 43^{\prime \prime} \mathrm{N}$ & $132^{\circ} 46^{\prime} 19^{\prime \prime} \mathrm{W}$ & 1995 & 6 & 60 \\
\hline 1463 & Falls Creek & $55^{\circ} 42^{\prime} 30^{\prime \prime} \mathrm{N}$ & $132^{\circ} 36^{\prime} 48^{\prime \prime} \mathrm{W}$ & 1975 & $\mathrm{U}$ & 57 \\
\hline 586 & Flood Creek & $63^{\circ} 26^{\prime} 42^{\prime \prime} \mathrm{N}$ & $145^{\circ} 48^{\prime} 0^{\prime \prime} \mathrm{W}$ & 1954 & 6 & 37 \\
\hline 1899 & Georges Creek & $61^{\circ} 28^{\prime} 00^{\prime \prime} \mathrm{N}$ & $148^{\circ} 48^{\prime} 12^{\prime \prime} \mathrm{W}$ & 1997 & $\mathrm{U}$ & 32 \\
\hline 1900 & Georges Creek & $61^{\circ} 28^{\prime} 06^{\prime \prime} \mathrm{N}$ & $148^{\circ} 48^{\prime} 06^{\prime \prime} \mathrm{W}$ & 1997 & $\mathrm{U}$ & 32 \\
\hline 445 & Good River & $58^{\circ} 24^{\prime} 54^{\prime \prime} \mathrm{N}$ & $135^{\circ} 46^{\prime} 18^{\prime \prime} \mathrm{W}$ & 1984 & 6 & 76 \\
\hline 1821 & Grouse Creek & $60^{\circ} 11^{\prime} 18^{\prime \prime} \mathrm{N}$ & $149^{\circ} 23^{\prime} 18^{\prime \prime} \mathrm{W}$ & 1988 & 6 & 37 \\
\hline 578 & Gunn Creek & $63^{\circ} 10^{\prime} 12^{\prime \prime} \mathrm{N}$ & $145^{\circ} 31^{\prime} 42^{\prime \prime} \mathrm{W}$ & 1954 & 6 & 81 \\
\hline 590 & Gunny Sack Creek & $63^{\circ} 29^{\prime} 18^{\prime \prime} \mathrm{N}$ & $145^{\circ} 51^{\prime} 24^{\prime \prime} \mathrm{W}$ & 1954 & 6 & 47 \\
\hline 2264 & Harriet Hunt Creek & $55^{\circ} 26^{\prime} 19^{\prime \prime} \mathrm{N}$ & $131^{\circ} 34^{\prime} 06^{\prime \prime} \mathrm{W}$ & 1961 & 6 & 53 \\
\hline 3000 & Hatchery Creek & $55^{\circ} 54^{\prime} 29^{\prime \prime} \mathrm{N}$ & $132^{\circ} 55^{\prime} 52^{\prime \prime} \mathrm{W}$ & 2003 & 6 & 120 \\
\hline 2129 & Hatchery Creek Tributary & $55^{\circ} 44^{\prime} 31^{\prime \prime} \mathrm{N}$ & $132^{\circ} 55^{\prime} 23^{\prime \prime} \mathrm{W}$ & 2006 & 6 & 93 \\
\hline 844 & Heney Creek & $60^{\circ} 31^{\prime} 24^{\prime \prime} \mathrm{N}$ & $145^{\circ} 46^{\prime} 54^{\prime \prime} \mathrm{W}$ & 1936 & 6 & 56 \\
\hline 1253 & Hunter Creek & $61^{\circ} 27^{\prime} 06^{\prime \prime} \mathrm{N}$ & $148^{\circ} 48^{\prime} 0^{\prime \prime} \mathrm{W}$ & 1995 & 6 & 80 \\
\hline 1685 & Jordan Creek & $58^{\circ} 23^{\prime} 12^{\prime \prime} \mathrm{N}$ & $134^{\circ} 39^{\prime} 54^{\prime \prime} \mathrm{W}$ & 1982 & $\mathrm{U}$ & 77 \\
\hline 893 & Kougarok River & $65^{\circ} 26^{\prime} 06^{\prime \prime} \mathrm{N}$ & $164^{\circ} 39^{\prime} 42^{\prime \prime} \mathrm{W}$ & 1941 & $\mathrm{U}$ & 183 \\
\hline 1713 & Little Susitna River Braid & $61^{\circ} 40^{\prime} 42^{\prime \prime} \mathrm{N}$ & $149^{\circ} 18^{\prime} 48^{\prime \prime} \mathrm{W}$ & 1974 & 6 & 41 \\
\hline 1717 & Log Jam Creek & $55^{\circ} 54^{\prime} 18^{\prime \prime} \mathrm{N}$ & $133^{\circ} 00^{\prime} 25^{\prime \prime} \mathrm{W}$ & 2003 & 6 & 96 \\
\hline 580 & McCallum Creek & $63^{\circ} 14^{\prime} 18^{\prime \prime} \mathrm{N}$ & $145^{\circ} 38^{\prime} 54^{\prime \prime} \mathrm{W}$ & 1954 & 6 & 33 \\
\hline 585 & Michael Creek & $63^{\circ} 26^{\prime} 06^{\prime \prime} \mathrm{N}$ & $145^{\circ} 46^{\prime} 48^{\prime \prime} \mathrm{W}$ & 1954 & 6 & 33 \\
\hline 1669 & Montana Creek & $62^{\circ} 00^{\prime} 0^{\prime \prime} \mathrm{N}$ & $150^{\circ} 00^{\prime} 0^{\prime \prime} \mathrm{W}$ & 1988 & $\mathrm{U}$ & 202 \\
\hline 1641 & Nataga Creek & $59^{\circ} 33^{\prime} 48^{\prime \prime} \mathrm{N}$ & $136^{\circ} 10^{\prime} 54^{\prime \prime} \mathrm{W}$ & 1984 & $\mathrm{U}$ & 48 \\
\hline 1457 & Newlunberry Creek & $55^{\circ} 41^{\prime} 48^{\prime \prime} \mathrm{N}$ & $132^{\circ} 46^{\prime} 12^{\prime \prime} \mathrm{W}$ & 1975 & $\mathrm{U}$ & 54 \\
\hline 1018 & North Fork Anchor River & $59^{\circ} 46^{\prime} 42^{\prime \prime} \mathrm{N}$ & $151^{\circ} 49^{\prime} 0^{\prime \prime} \mathrm{W}$ & 1965 & 6 & 43 \\
\hline 1409 & Pats Creek & $56^{\circ} 20^{\prime} 06^{\prime \prime} \mathrm{N}$ & $132^{\circ} 20^{\prime} 12^{\prime \prime} \mathrm{W}$ & 1973 & $\mathrm{U}$ & 104 \\
\hline 1501 & Peters Creek & $61^{\circ} 24^{\prime} 42^{\prime \prime} \mathrm{N}$ & $149^{\circ} 31^{\prime} 48^{\prime \prime} \mathrm{W}$ & 1989 & $\mathrm{U}$ & 61 \\
\hline 432 & Sawmill Creek & $57^{\circ} 03^{\prime} 6^{\prime \prime} \mathrm{N}$ & $135^{\circ} 13^{\prime} 48^{\prime \prime} \mathrm{W}$ & 1962 & 6 & 165 \\
\hline 1098 & Smith Creek & $66^{\circ} 04^{\prime} 18^{\prime \prime} \mathrm{N}$ & $162^{\circ} 43^{\prime} 24^{\prime \prime} \mathrm{W}$ & 1979 & 6 & 116 \\
\hline 1199 & South Fork Anchor River & $59^{\circ} 42^{\prime} 06^{\prime \prime} \mathrm{N}$ & $151^{\circ} 37^{\prime} 54^{\prime \prime} \mathrm{W}$ & 1966 & $\mathrm{U}$ & 72 \\
\hline 2138 & Swiftwater Creek & $61^{\circ} 39^{\prime} 00^{\prime \prime} \mathrm{N}$ & $149^{\circ} 30^{\prime} 24^{\prime \prime} \mathrm{W}$ & 2004 & $\mathrm{U}$ & 47 \\
\hline 309 & Taiya River & $59^{\circ} 30^{\prime} 48^{\prime \prime} \mathrm{N}$ & $135^{\circ} 20^{\prime} 42^{\prime \prime} \mathrm{W}$ & 1946 & $\mathrm{U}$ & 205 \\
\hline 463 & Takotna River & $62^{\circ} 58^{\prime} 06^{\prime \prime} \mathrm{N}$ & $156^{\circ} 05^{\prime} 24^{\prime \prime} \mathrm{W}$ & 1941 & $\mathrm{U}$ & 255 \\
\hline 462 & Tatalina River & $62^{\circ} 53^{\prime} 6^{\prime \prime} \mathrm{N}$ & $155^{\circ} 56^{\prime} 24^{\prime \prime} \mathrm{W}$ & 1947 & 6 & 61 \\
\hline 584 & Trims Creek & $63^{\circ} 25^{\prime} 24^{\prime \prime} \mathrm{N}$ & $145^{\circ} 45^{\prime} 18^{\prime \prime} \mathrm{W}$ & 1954 & $\mathrm{U}$ & 37 \\
\hline 1731 & Trocodero Creek & $55^{\circ} 24^{\prime} 16^{\prime \prime} \mathrm{N}$ & $132^{\circ} 49^{\prime} 33^{\prime \prime} \mathrm{W}$ & 1964 & $\mathrm{U}$ & 92 \\
\hline 2281 & Trumpeter Creek & $55^{\circ} 58^{\prime} 59^{\prime \prime} \mathrm{N}$ & $132^{\circ} 52^{\prime} 19^{\prime \prime} \mathrm{W}$ & 2006 & 6 & 95 \\
\hline 607 & Victor Creek & $60^{\circ} 21^{\prime} 30^{\prime \prime} \mathrm{N}$ & $149^{\circ} 20^{\prime} 54^{\prime \prime} \mathrm{W}$ & 1952 & 6 & 198 \\
\hline 1490 & West Creek & $59^{\circ} 31^{\prime} 36^{\prime \prime} \mathrm{N}$ & $135^{\circ} 21^{\prime} 0^{\prime \prime} \mathrm{W}$ & 1992 & $\mathrm{U}$ & 163 \\
\hline 587 & Whistler Creek & $63^{\circ} 26^{\prime} 12^{\prime \prime} \mathrm{N}$ & $145^{\circ} 50^{\prime} 30^{\prime \prime} \mathrm{W}$ & 1954 & 6 & 37 \\
\hline 464 & Yankee Creek & $63^{\circ} 03^{\prime} 54^{\prime \prime} \mathrm{N}$ & $156^{\circ} 20^{\prime} 24^{\prime \prime} \mathrm{W}$ & 1937 & 6 & 44 \\
\hline
\end{tabular}




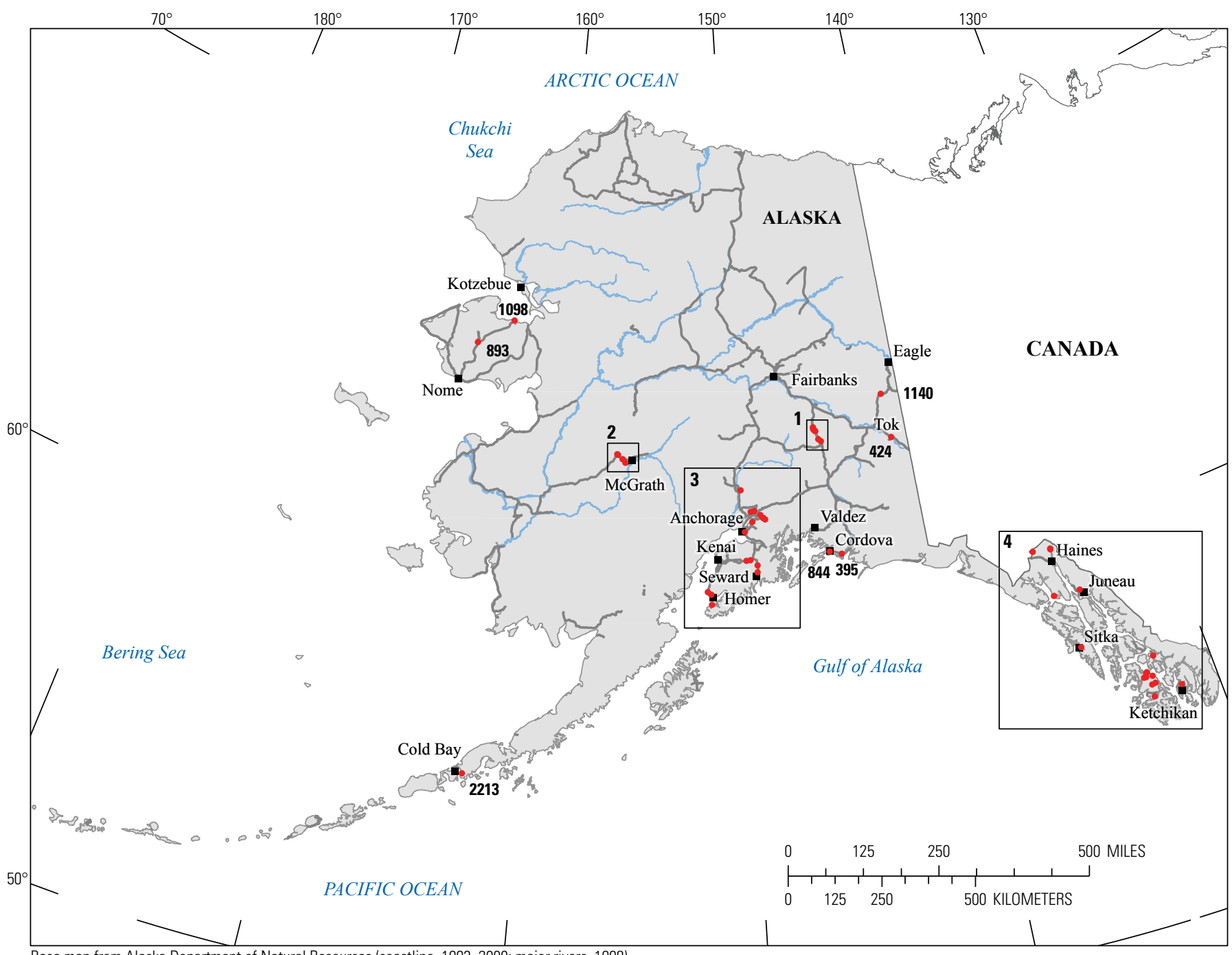

Base map from Alaska Department of Natural Resources (coastline, 1993, 2000; major rivers, 1998),

Alaska Department of Transportation (major roads, 2007), Alaska Department of Natural Resources (towns,1998)

World Geodetic System of 1984
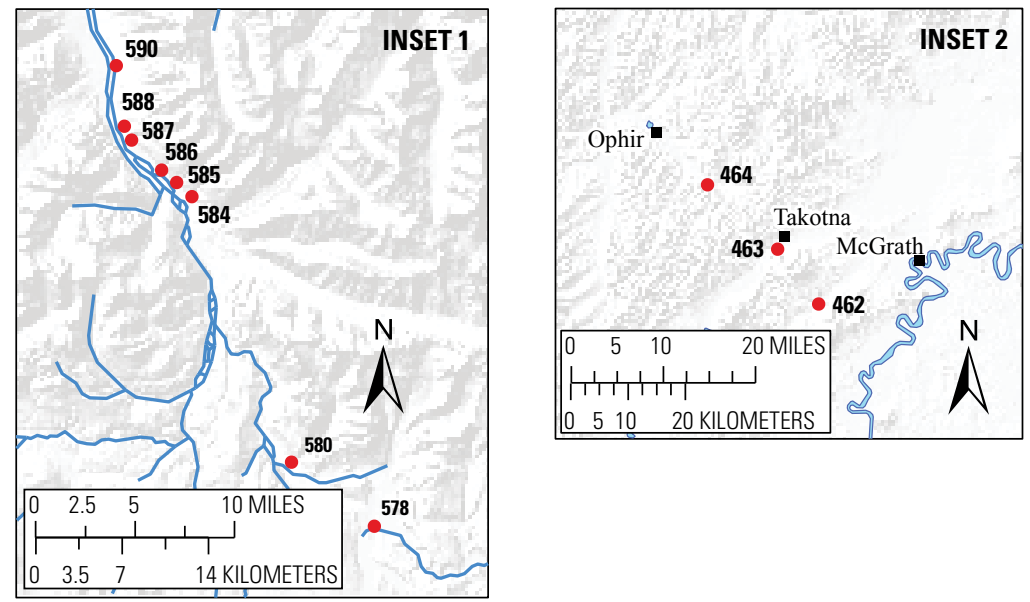

\section{EXPLANATION}

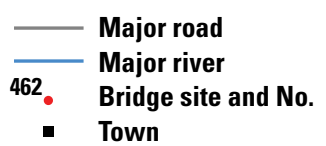

Figure 2. Locations of selected bridge sites in Alaska where scour was evaluated. 



Figure 2.-Continued

\section{Methods}

\section{Stream Stability and Geomorphic Assessment}

Arneson and others (2012) recommended that a general assessment of stream stability, aggradation, or degradation following guidelines in Lagasse and others (2012) be done as a first step in a scour assessment. Many streams in Alaska are naturally unstable because of high gradient, large sediment supply, lack of containment, or relatively frequent overbank floods. Some also have been either destabilized or stabilized by human activity, including dredging, in-stream mining, and erosion control. These factors may influence the vulnerability of structures and embankments to scour and erosion. The general geomorphic setting of each stream channel was determined using aerial photographs, light detection and ranging (lidar), ADOT\&PF bridge inspection reports, and on-site assessments by USGS personnel. Stream stability was classified qualitatively based on evidence of channel change, active sediment sources, and human disturbance (excluding the bridge). 
Since 1998, ADOT\&PF has done biannual soundings (depth-from-bridge measurements) on the upstream side of bridges in conjunction with bridge inspections. The USGS did soundings on the upstream and downstream sides of bridges for this study. Because ADOT\&PF inspectors and the USGS personnel typically took depth measurements at different locations along the bridge face and used slightly different techniques, only the minimum bed elevation was compared between surveys done by the different agencies. The average change in minimum bed elevation between successive soundings (1-2 years apart) was used to look for evidence of channel aggradation or degradation, and the maximum change from the highest minimum bed elevation and the lowest minimum bed elevation was used to determine relative stream stability. Divisions in relative stream stability categories were based on natural breaks in the data. Stream size determines changes in bed elevation to some extent (Lagasse and others, 2012). In order to compare different sized streams, elevation changes were normalized by modeled 100 -year channel width at the bridge opening. Sites with less than $\pm 0.4 \mathrm{ft}$ of relative change per $10 \mathrm{ft}$ of channel width between surveys were considered stable, sites with greater than or equal to $\pm 0.4 \mathrm{ft}$ of change per $10 \mathrm{ft}$ of channel width were considered less stable, and sites with greater than or equal to $\pm 0.8 \mathrm{ft}$ of change in minimum bed elevation per $10 \mathrm{ft}$ of channel width were considered least stable.

\section{Flood Frequency Calculations}

It is standard engineering practice to design bridges to safely withstand the hydraulic conditions encountered during a large, rare flood, referred to as the design flood. Scour at the bridge site also is calculated for an even larger flood, known as the check flood or super flood. The design flood and check flood typically are 1- and 0.2-percent annual exceedance probability (AEP) floods (also referred to as "100- and 500-year recurrence interval floods"), respectively (Arneson and others, 2012). The AEP is the probability that a select flow will be equaled or exceeded annually. For example, a 0.01 AEP flow has a 1-percent chance of being equaled or exceeded in any given year. Smaller AEP (higher probability) floods also may be used as design floods or check floods if they exceed the channel capacity and intersect the superstructure of the bridge, causing pressure flow (Arneson and others, 2012). Scour was calculated for the 1- and 0.2-percent AEP floods or pressure flow floods, based on flood frequency calculations, with a few exceptions. The flood magnitudes used in this report may differ from the original design flood for the bridge.

Regional regression equations developed by Curran and others (2016) were used to calculate the 1- and 0.2-percent AEP floods. For sites with streamgages or crest-stage gages at or near the bridge, PeakFQ version 7.0 software (Veilleux and others, 2013) was used to do a modified Bulletin 17B flood-frequency analysis (Interagency Advisory Committee on Water Data, 1982). The modifications include the use of an Expected Moments Algorithm (EMA) and a multiple GrubbsBeck test (Veilleux and others, 2013). The EMA allows more flexibility in incorporating observations and floods outside of the streamgage record. The multiple Grubbs-Beck test identifies and disregards low peak flows that may substantially influence the shape of the flood-frequency curve. The 1- and 0.2-percent AEP flows calculated for gaged sites with the EMA analysis were then combined with the regional regression analysis results to obtain a final weighted value as described in Curran and others (2016). The regression variables (drainage area and mean annual precipitation) used for each site and gaged period of record are shown in table 2 .

Table 2. Variables used in the flood frequency analysis for selected bridges in Alaska, 2013-15.

[Abbreviations and symbol: in., inch ; $\mathrm{mi}^{2}$, square mile; -, variables either are unavailable or are not used in flood frequency analysis]

\begin{tabular}{|c|c|c|c|c|c|c|}
\hline $\begin{array}{l}\text { Bridge } \\
\text { No. } \\
\text { (fig. 2) }\end{array}$ & Stream name & $\begin{array}{c}\text { Streamgage } \\
\text { No. }\end{array}$ & $\begin{array}{l}\text { Period of record for } \\
\text { peak streamflow } \\
\text { analysis }\end{array}$ & $\begin{array}{l}\text { Number } \\
\text { of peaks }\end{array}$ & $\begin{array}{l}\text { Drainage } \\
\text { area } \\
\left(\mathrm{mi}^{2}\right)\end{array}$ & $\begin{array}{c}\text { Mean annual } \\
\text { precipitation } \\
\text { (in.) }\end{array}$ \\
\hline 395 & Alaganik Slough & - & - & - & 24.7 & 166 \\
\hline 433 & Barabara Creek & 15238820 & $1972-92,2002$ & 21 & 20.6 & 71 \\
\hline 2213 & Barney Creek & - & - & - & 6.0 & 59 \\
\hline 1935 & Bodenburg Creek & - & - & - & 0.6 & 15 \\
\hline 588 & Boulder Creek & - & - & - & 3.5 & 47 \\
\hline 645 & Campbell at Old Seward & 15274600 & ${ }^{1} 2006-15$ & 10 & 43.1 & 32 \\
\hline 1140 & Chicken Creek & - & - & - & 17.6 & 13 \\
\hline 424 & Chisana River & 15470000 & $1950-71$ & 22 & $2,960.0$ & 16 \\
\hline
\end{tabular}


Table 2. Variables used in the flood frequency analysis for selected bridges in Alaska, 2013-15.-Continued

\begin{tabular}{|c|c|c|c|c|c|c|}
\hline $\begin{array}{c}\text { Bridge } \\
\text { No. } \\
\text { (fig. 2) }\end{array}$ & Stream name & $\begin{array}{c}\text { Streamgage } \\
\text { No. }\end{array}$ & $\begin{array}{l}\text { Period of record for } \\
\text { peak streamflow } \\
\text { analysis }\end{array}$ & $\begin{array}{l}\text { Number } \\
\text { of peaks }\end{array}$ & $\begin{array}{c}\text { Drainage } \\
\text { area } \\
\left(\mathbf{m i}^{2}\right)\end{array}$ & $\begin{array}{l}\text { Mean annual } \\
\text { precipitation } \\
\text { (in.) }\end{array}$ \\
\hline 2282 & Coffman Creek & - & - & - & 4.8 & 94 \\
\hline 674 & Cooper Creek & 15261000 & $1962-2012$ & 23 & 49.3 & 62 \\
\hline 1021 & Crescent Creek & 15254000 & $1950-83$ & 34 & 31.6 & 56 \\
\hline 2283 & Dog Creek & - & - & - & 2.1 & 90 \\
\hline 2279 & Dog Creek Tidal & - & - & - & 3.0 & 87 \\
\hline 1463 & Falls Creek & - & - & - & 3.4 & 126 \\
\hline 586 & Flood Creek & - & - & - & 3.8 & 47 \\
\hline 1900 & Georges Creek & - & - & - & 3.9 & 23 \\
\hline 1899 & Georges Creek & - & - & - & 3.7 & 23.3 \\
\hline 445 & Good River & - & - & - & 33.2 & 66 \\
\hline 1821 & Grouse Creek & 15237730 & 1998-2015 & 17 & 5.9 & 66 \\
\hline 578 & Gunn Creek & - & - & - & 50.6 & 29 \\
\hline 590 & Gunny Sack Creek & - & - & - & 4.6 & 51 \\
\hline 2264 & Harriet Hunt Creek & - & - & - & 3.0 & 156 \\
\hline 3000 & Hatchery Creek & - & - & - & 38.2 & 106 \\
\hline 2129 & Hatchery Creek Tributary & - & - & - & 1.8 & 110 \\
\hline 844 & Heney Creek & - & - & - & 1.5 & 200 \\
\hline 1253 & Hunter Creek & - & - & - & 69.3 & 41 \\
\hline 1685 & Jordan Creek & - & - & - & 1.1 & 88 \\
\hline 893 & Kougarok River & - & - & - & 53.5 & 15 \\
\hline 1713 & Little Susitna Braid & 15290000 & 1949-2015 & 67 & 76.0 & 42.3 \\
\hline 1717 & Log Jam Creek & - & - & - & 37.5 & 102 \\
\hline 580 & McCallum Creek & 15478050 & 1967-91 & 25 & 15.0 & 36 \\
\hline 585 & Michael Creek & - & - & - & 3.6 & 48 \\
\hline 1669 & Montana Creek & 15292800 & $1963-72,1986,2005-15$ & 20 & 157.3 & 34 \\
\hline 1641 & Nataga Creek & - & - & - & 32.8 & 76 \\
\hline 1457 & Newlunberry Creek & - & - & - & 0.8 & 69 \\
\hline 1018 & North Fork Anchor River & - & - & - & 29.7 & 29 \\
\hline 1409 & Pats Creek & - & - & - & 7.0 & 105 \\
\hline 1501 & Peters Creek & 15277410 & 1974-95 & 22 & 86.9 & 108 \\
\hline 432 & Sawmill Creek & 15088000 & ${ }^{2} 2002-15$ & 13 & 38.7 & 198 \\
\hline 1098 & Smith Creek & - & - & - & 23.9 & 12 \\
\hline 1199 & South Fork Anchor River & - & - & - & 120.2 & 31 \\
\hline 2138 & Swiftwater Creek & - & - & - & 4.9 & 32 \\
\hline 309 & Taiya River & 15056210 & 1967-2012 & 19 & 184.0 & 76 \\
\hline 463 & Takotna River & - & - & - & 242.7 & 19 \\
\hline 462 & Tatalina River & 15303700 & 1987-2012 & 25 & 75.8 & 17 \\
\hline 584 & Trims Creek & - & - & - & 5.2 & 50 \\
\hline 1731 & Trocodero Creek & - & - & - & 5.0 & 146 \\
\hline 2281 & Trumpeter Creek & - & - & - & 15.8 & 109 \\
\hline 607 & Victor Creek & - & - & - & 13.0 & 102 \\
\hline 1490 & West Creek & 15056200 & $1962-77$ & 16 & 43.0 & 74 \\
\hline 587 & Whistler Creek & - & - & - & 3.0 & 35 \\
\hline 464 & Yankee Creek & - & - & - & 24.0 & 19 \\
\hline
\end{tabular}

${ }^{1}$ Campbell Creek streamgage (downstream of bridge) also operated between 1978 and 1992. However, this was prior to much of the urbanization of the basin, so these years were not used.

${ }^{2}$ Sawmill Creek streamgage also operated from 1921 to 1957. This was prior to the construction of the Blue Lake Dam and peaks measured after construction were significantly different. 


\section{Field Surveys and Data Sources}

In addition to flood flows, the basic data needed for a scour evaluation using a one-dimensional model include:

1. Bridge geometry as measured in the field;

2. Channel and overbank geometry, including approach and exit cross sections located outside the expansion and contraction zone of the bridge and cross sections immediately upstream and downstream of the bridge;

3. Water-surface slope for boundary conditions;

4. Bed-material size for determination of live-bed or clearwater scour;

5. An estimate of the channel and flood plain Manning's roughness coefficients (n); and

6. A discharge measurement for model calibration.

7. Geometric, grain size, and Manning's n data and sources for each site are listed in table 3 .

\section{Stream Cross Sections and Bridge Geometry Surveys}

A datum point established at each site was used to determine relative elevations of the channel cross sections and bridge geometry. Streambed elevations were measured at the upstream and downstream face of each bridge using either sounding weights on cable reels, weighted measuring tapes, or acoustic Doppler current profilers (ADCPs), depending on the depth and current. Channel cross sections and water-surface slopes were surveyed with either a total station or an optical level with a stadia rod and range finder. ADCPs were used to survey bathymetry where channels were too deep to wade. Bridge-deck elevation and slope, low-chord elevation, bridge width, and the location and dimensions of piers and footings also were measured if construction plans were insufficient. Overbank areas were sometimes either inaccessible or too thickly vegetated to survey. In these cases, elevations derived from lidar or USGS Digital Raster Graphic topographic maps supplemented the data on overbank geometry. Where stream gradients were low relative to errors in surveying, gradients were measured from lidar or topographic maps.

\section{Discharge Measurements for Calibration}

USGS crews measured discharge at every site except Chicken Creek Bridge 1140, which was dry at the time of the visit, and Yankee Creek Bridge 464, where flow was blocked by beaver dams. Discharge was measured with a current meter or an ADCP, depending on the size of the stream. All discharge measurements were obtained during low water conditions, except at Taiya River Bridge 309 and West Creek Bridge 1490, where discharge measurements were obtained during moderate flow conditions.

\section{Grain-Size Analysis}

Grain-size distribution, which is needed to check for live-bed or clear-water scour conditions and to calculate clear-water scour, was determined at all gravel-bedded sites using either a gravelometer or digital image analysis software (Bergendahl and Arneson, 2014). At eight sites, both methods were used. A sieve analysis was used for the four sand-bedded sites. Streambed material at all sites was greater than the 0.2 -mm median diameter grain-size $\left(D_{50}\right)$ threshold for cohesive behavior.

\section{Hydraulic Model Development}

The Hydrologic Engineering Center River Analysis System version 5.03 (HEC-RAS) (Brunner, 2016) was used to compute water-surface profiles and hydraulic variables needed for scour equations. HEC-RAS is a one-dimensional step-backwater model with steady- and unsteady-flow components.

HEC-RAS requires a flow file and geometry file to run. Steady-flow files include design floods and discharge measurements for model calibration and boundary conditions. Unsteady-flow files include a hydrograph for each flow and a downstream boundary condition. All sites used normal depth for the downstream boundary conditions for floods. The water-surface slope that was surveyed at low water initially was used as a downstream boundary condition. If the simulated water-surface profile showed a downturn or upturn at the downstream-most cross section, the slope was adjusted within reasonable limits to better match the simulated high-flow water-surface slopes. Subcritical, supercritical, or mixed-flow regime modes can be modeled. Flow conditions initially were assumed to be subcritical, but if HEC-RAS identified critical flow at a cross section, an upstream normal depth boundary condition was added to steady-flow models and the model was re-run in a mixed-flow regime. Surveyed water-surface elevations were compared to model simulation results and used to validate or refine channel roughness values.

Geometry files included 4-6 cross sections, following the suggestion in the HEC-RAS Hydraulic Reference Guide (Brunner, 2016). For the 2013 and 2014 sites, the channel elevations from the bridge soundings were used both for the internal bridge cross sections and for the two cross sections bounding the bridge, but the sections were shifted upstream and downstream 5-15 ft in the model to allow for contraction and expansion between the cross sections and the bridge and elevations were adjusted to match the gradient of the reach. 


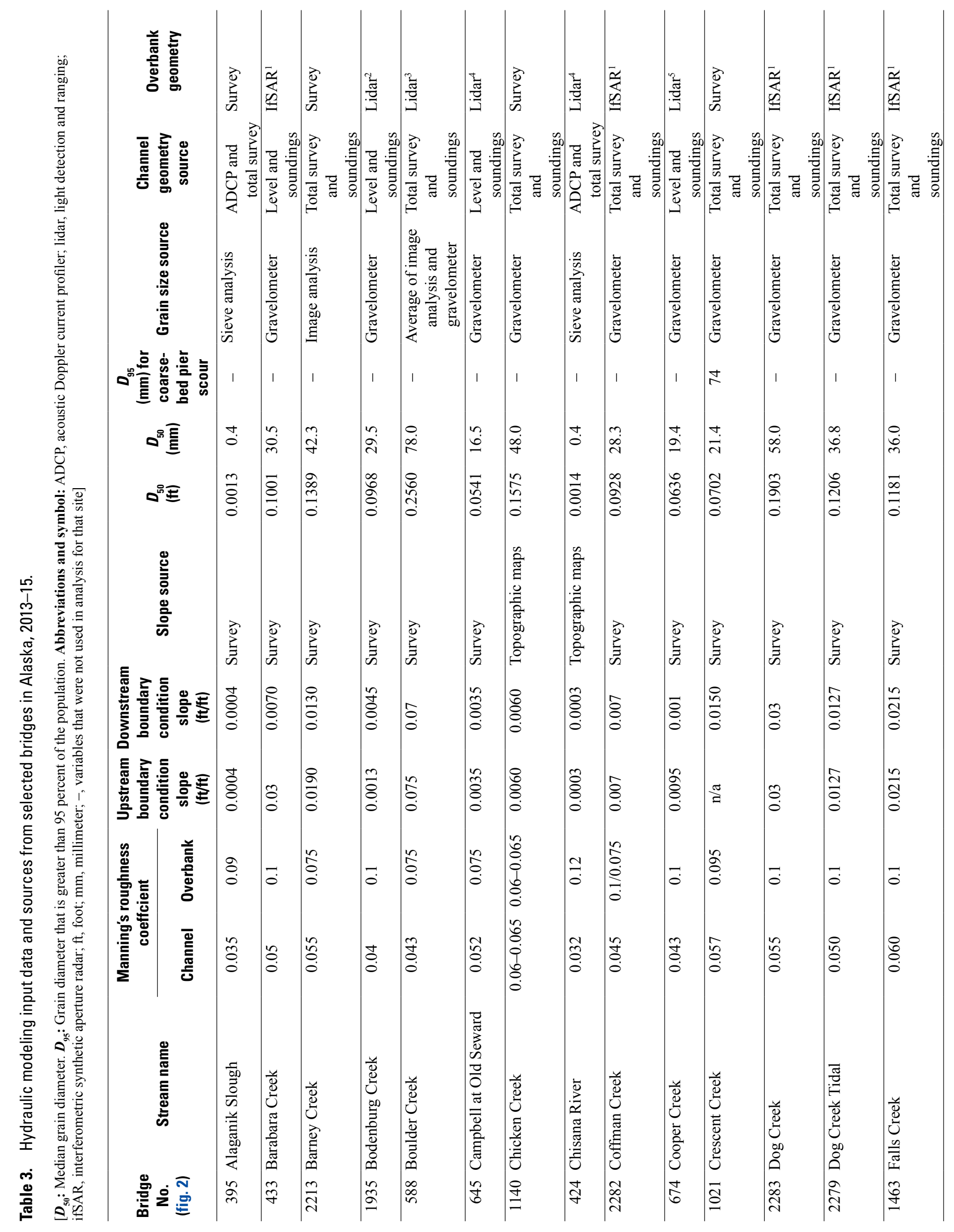




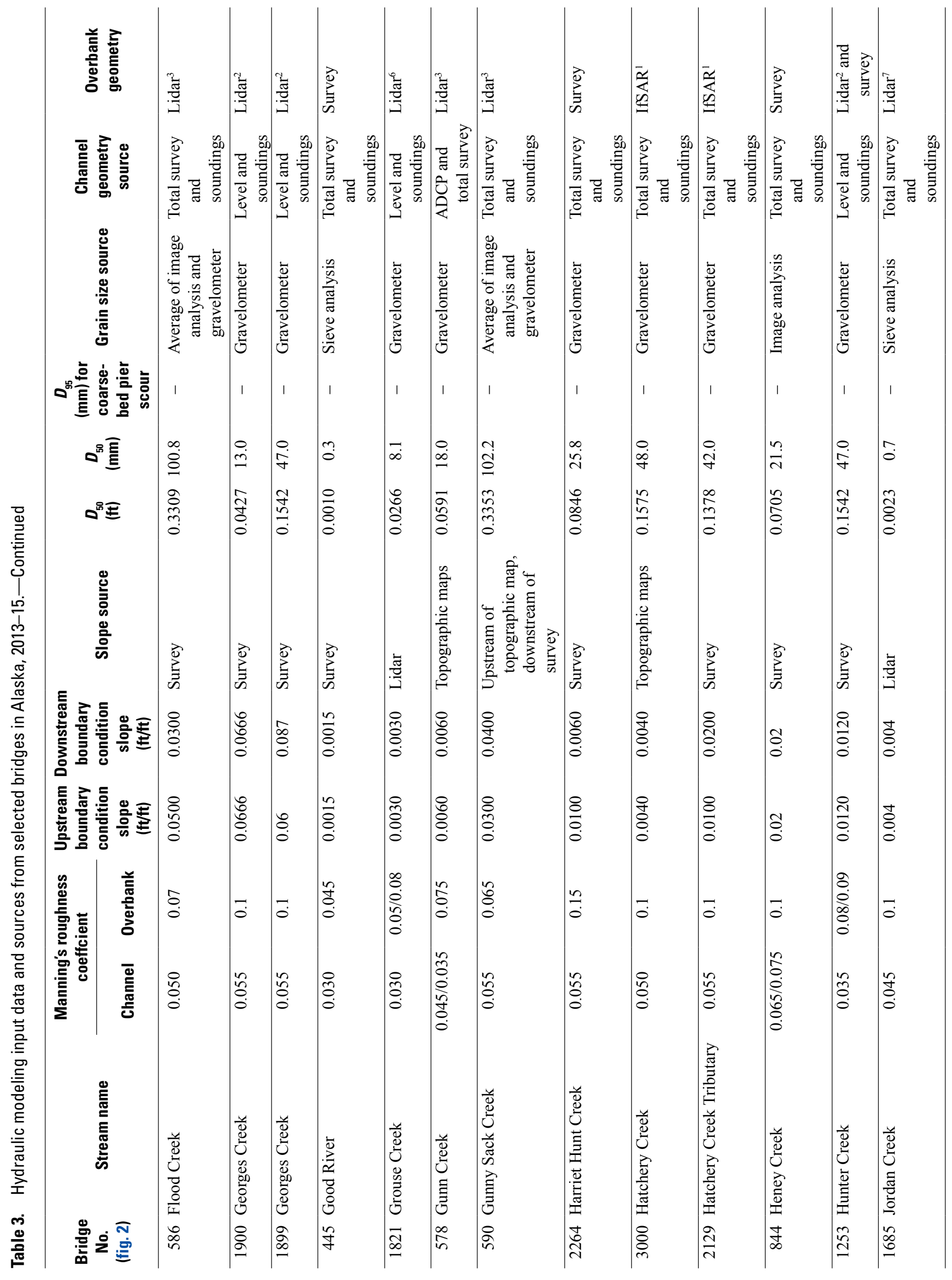




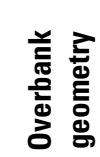

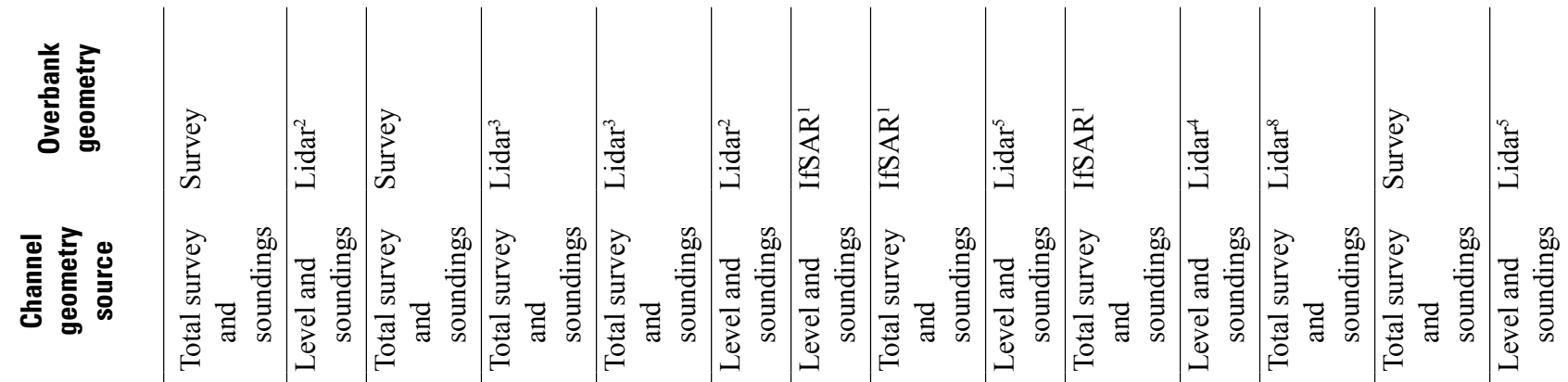

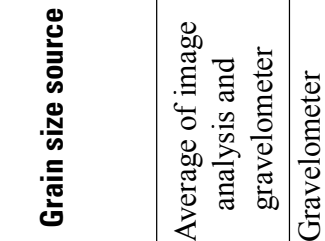

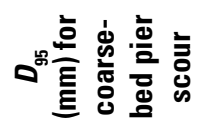

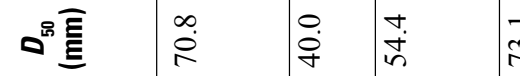

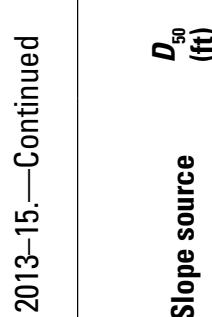

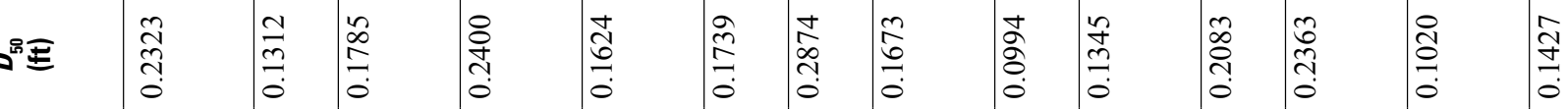
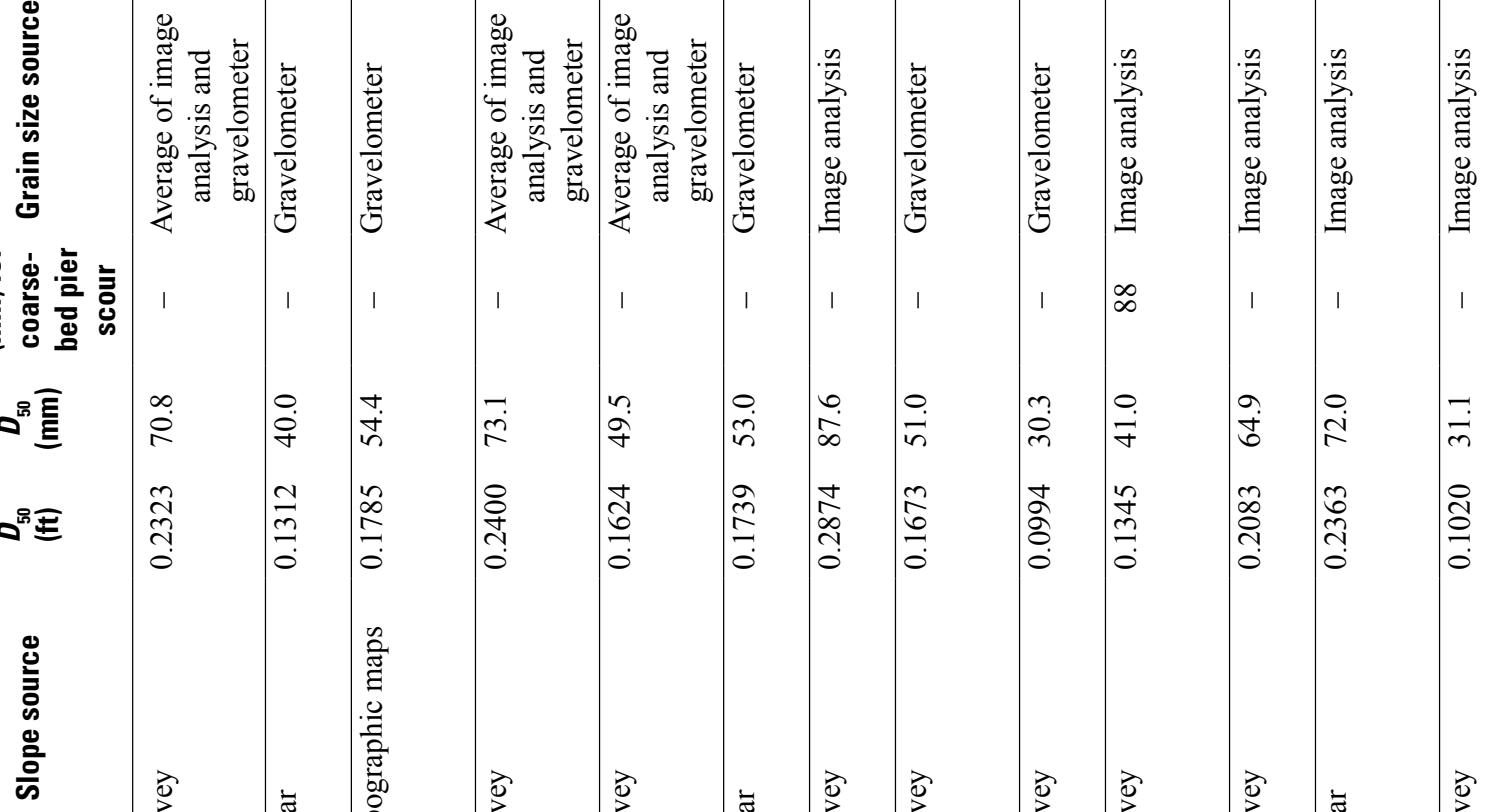

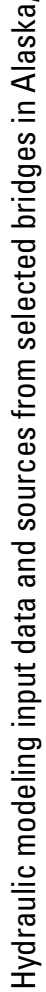

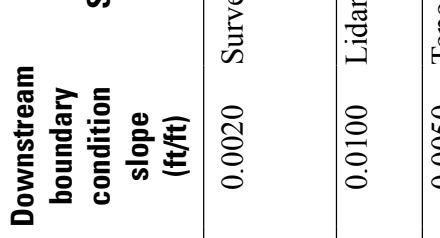
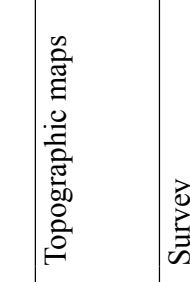

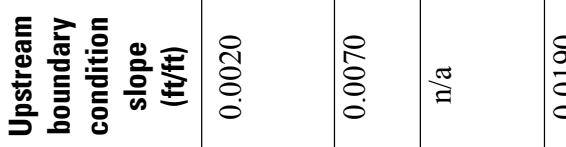

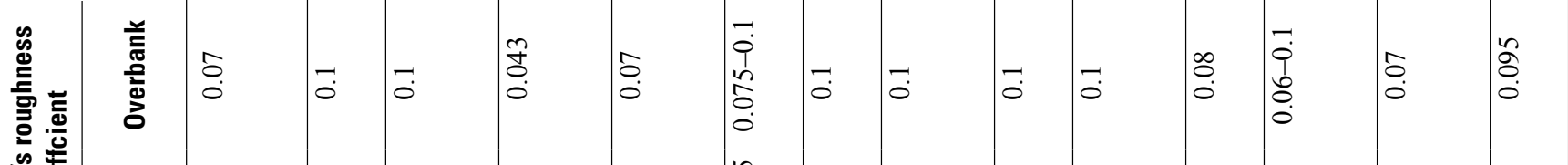

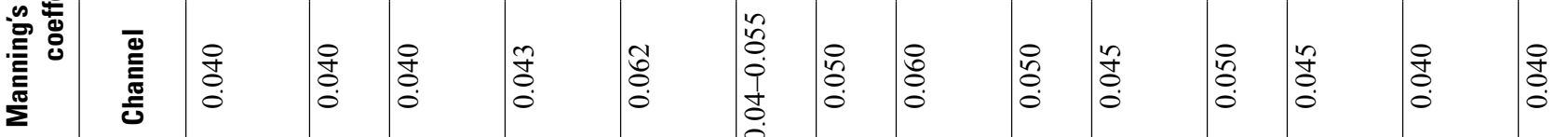




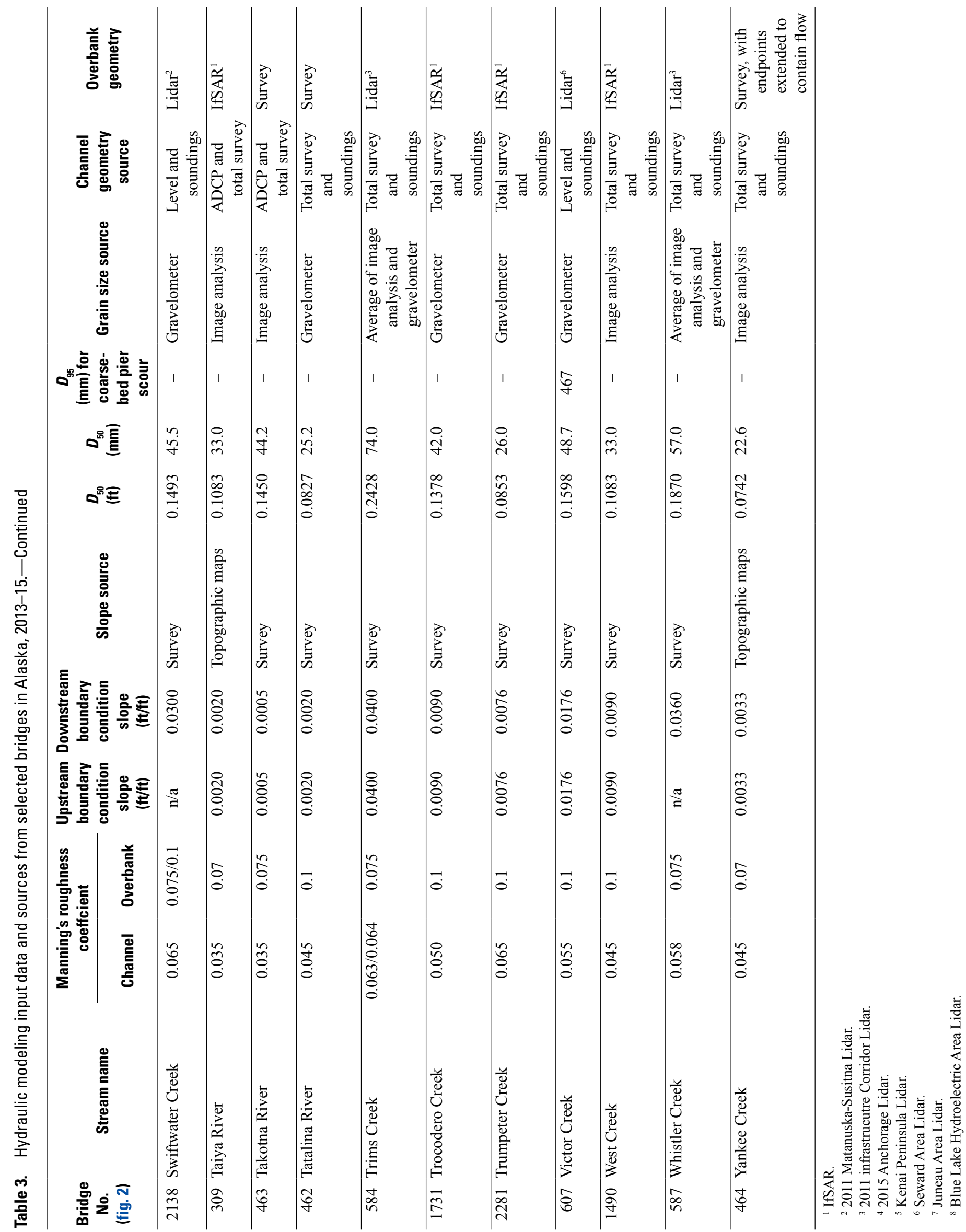


For the 2015 sites, additional cross sections upstream and downstream of the bridge were surveyed, and the soundings were only used for the internal bridge cross sections. The approach and exit sections were located during the survey outside the probable contraction and expansion zones upstream and downstream of the bridge.

Channel roughness coefficients at the discharge measurement sites were computed using Manning's equation. Roughness coefficient values for the overbanks were determined using visual methods following Chow (1959) and Hicks and Mason (1998). In most cases, measured discharge was extremely low relative to flood discharges, and channel roughness coefficients derived from Manning's roughness equation were unrepresentative of expected conditions. The channel roughness coefficients also were estimated using visual methods (Chow, 1959; Hicks and Mason, 1998).

Because Manning's roughness coefficient can change with flow, it was varied within a reasonable range to improve model stability at the 1- and 0.2-percent AEP flows. Manning's roughness varied from cross section to cross section if there were significant changes in overbank vegetation.

In most cases, geometry was compiled from survey data and entered manually in HEC-RAS. However, where overbank flow was significant, and water-surface profiles depended on topographic detail in the flood plains, the geometry was supplemented with overbank elevations from lidar data, georeferenced topographic maps, or IfSAR (interferometric synthetic aperture radar)-derived elevation data. Incorporating overbank data from other sources is primarily helpful in identifying preferential flow paths in complex flood plains and determining where overflow of the bridge approaches might occur.

\section{Scour Calculations}

Methods for calculating scour varied with site conditions. Sediment transport conditions upstream of the bridge determined whether live-bed or clear-water equations were used. Pier-scour methods included both simple and complex pier scour, depending on the geometry of the exposed pier, and accounted for the effects of debris accumulations. Pier scour is additive with contraction scour. A single abutment scour method that incorporates contraction scour was used for all sites to estimate total scour depth at each abutment.

\section{Contraction Scour}

Contraction scour can have horizontal and vertical components. Horizontal contraction scour is caused by road approach embankments and abutments in the flood plain or main channel that intercept flow and direct it through the bridge opening. Vertical contraction scour occurs when the superstructure of the bridge (girders, deck, curb, and railing) intercepts the water surface, creating pressure flow conditions.
In both cases, contraction scour occurs because, as flow accelerates through a smaller cross section, velocity and shear stress increase and transport streambed material downstream. As scour deepens a channel, cross-sectional area increases and shear stress and velocity decrease until scour reaches equilibrium depth (also referred to as the depth of maximum scour). Contraction scour is calculated and presented as a uniform lowering of the streambed across the channel cross section (fig. 3), but it rarely actually works that way because some areas of the streambed are more erodible than other areas, and flow is not evenly distributed across the channel. Contraction scour is calculated differently depending on the sediment transport properties of the approach channel, whether pressure flow is present, and whether streambed material is cohesive or non-cohesive. All methods assume that the simulated flood lasts long enough to cause maximum scour, and that the width of the contracted section remains constant and only depth increases until equilibrium depth is reached. In practice, erosion of embankments under a bridge often causes the channel to widen and deepen during a flood.

\section{Clear-Water Compared with Live-Bed Contraction Scour}

Cohesionless contraction scour is calculated differently depending on whether the approach channel is transporting sediment into the bridge section (live-bed scour) or not (clear-water scour). For live-bed conditions, maximum scour depth is reached when sediment transported out of the bridge section equals the sediment transported in from the approach section. For clear-water conditions, maximum scour depth is reached when the shear stress in the bridge section decreases to the critical shear stress of the bed material in the section and sediment transport ceases.

Live-bed or clear-water conditions for each simulated flow were determined by using equation 1 to compare the simulated velocity in the approach cross section with the critical velocity necessary to transport the median grain size $\left(D_{50}\right)$. If the simulated velocity in the approach cross section did not exceed the critical velocity needed to transport the median grain size, then clear-water scour equations were used. If the simulated velocity at the approach cross section exceeded the critical velocity needed to transport the median grain size, then live-bed equations were used to calculate scour. If physical evidence of either live-bed or clear-water conditions were observed in the field, these observations were used to determine which equation to use. For instance, in some cases, scour holes were evident in the field, but the applicable equation predicted no scour. In cases of extreme backwater, such as those that occur when flow reaches the superstructure of the bridge, the velocity in the approach section will drop below the critical velocity for sediment transport, and scour will change from a live-bed to a clear-water condition at the bridge (Arneson and others, 2012). This can cause conditions at a site to change from live-bed to clear-water between the design and check floods. 


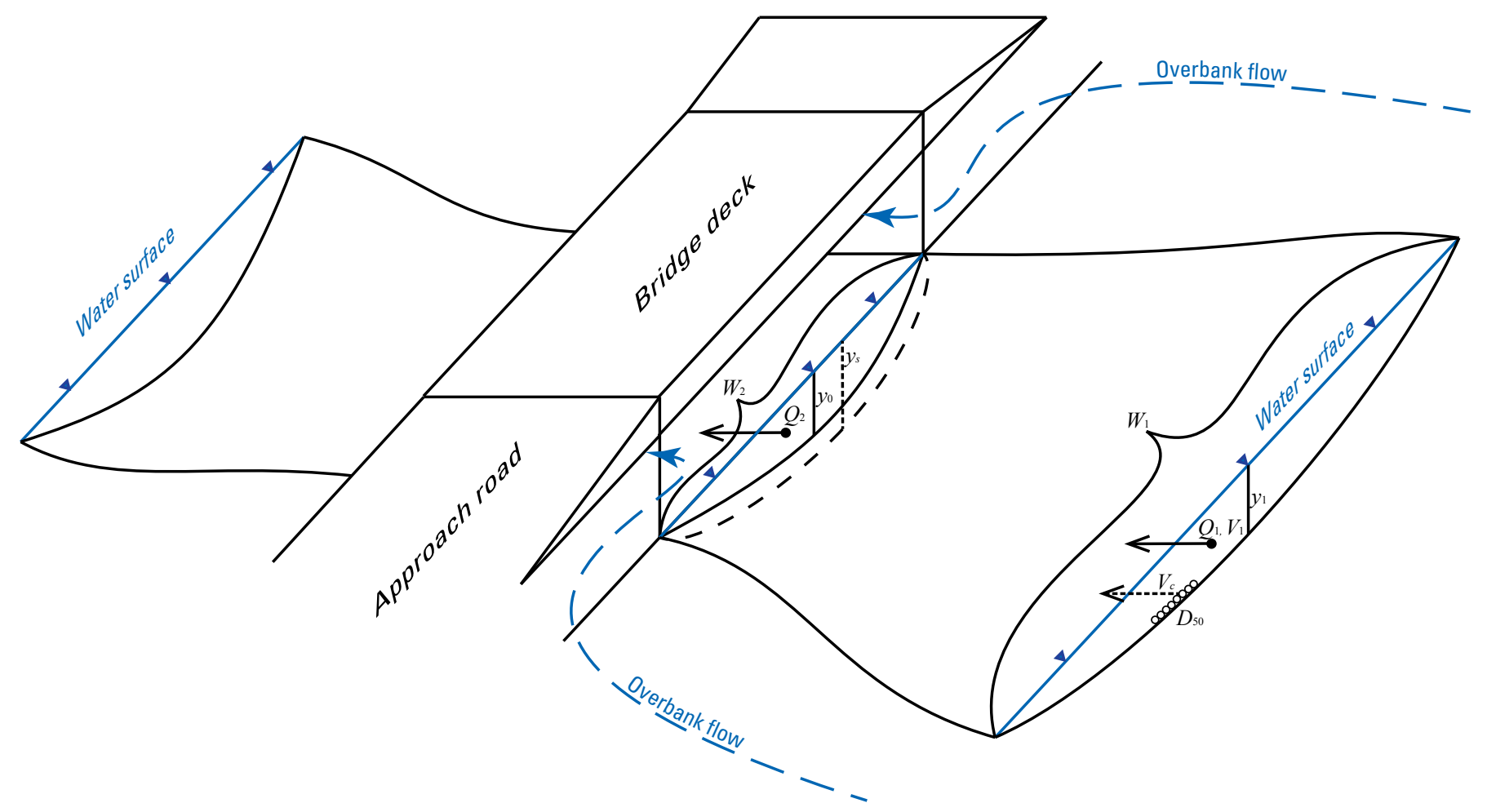

Figure 3. Basic contraction scour conditions and variables defined in equations 1-3.

$$
V_{c}=11.17 y^{1 / 6} D_{50}{ }^{1 / 3}
$$

where

$V_{c} \quad$ is the critical velocity above which $D_{50}$ grain size and smaller will be transported, in feet per second;

$y^{1} \quad$ is the average depth of flow upstream of the bridge, in feet; and

$D_{50} \quad$ is the median diameter of bed material, in feet.

\section{Live-Bed Contraction Scour}

Live-bed contraction scour is calculated using equation 2 (Arneson and others, 2012). The equation depends on the ratios of discharge and width between the approach section and the contracted section, as well as the depths in the approach section and contracted section. The live-bed equation will only estimate scour if there is a decrease in width and (or) an increase in discharge between the approach channel and the bridge section. Because it does not include grain size, the live-bed equation may overestimate actual scour when the contracted section is armored.

$$
y_{s}=y_{1}\left[\left(\frac{Q_{2}}{Q_{1}}\right)^{\frac{6}{7}}\left(\frac{W_{1}}{W_{2}}\right)^{k_{1}}\right]-y_{0}
$$


where

$y_{s} \quad$ is the live-bed average contraction scour depth, in feet;

$y_{1}$ is the average depth in the main channel of the approach section, in feet;

$y_{0} \quad$ is the average depth in the contracted section before scour, in feet;

$Q_{1} \quad$ is the discharge in the main channel of the approach section that is transporting sediment, in cubic feet per second;

$Q_{2} \quad$ is the discharge in the contracted section (bridge), in cubic feet per second;

$W_{1} \quad$ is the width of the main channel of the approach section that is transporting sediment, in feet;

$W_{2} \quad$ is the width (less pier widths) of the of the main channel in the contracted section (bridge) that is transporting sediment, in feet; and

$k_{1} \quad$ is a coefficient determined by comparing shear velocity to the fall velocity of the $D_{50}$ bed material (see Arneson and others, 2012, p 6.10), which varies from 0.59 to 0.69 .

\section{Clear-Water Contraction Scour}

If the velocity in the approach channel is less than the critical velocity for sediment transport, Arneson and others (2012) recommended using the clear-water contraction scour equation (eq. 3). The clear-water equation depends only on conditions in the contracted section, and will calculate increasing scour for decreasing median sediment size. The clear-water equation will overestimate scour when the approach section velocity is less than the critical velocity, but the bridge section is narrow and deep, or when the bridge channel is armored with gravel significantly larger than the median. The clear-water equation does not take into account the relative widths of the approach channel and bridge section, so no physical contraction is necessary to produce contraction scour.

$$
y_{s}=\left[\frac{0.0077 Q^{2}}{\left(1.25 D_{50}\right)^{2 / 3} W^{2}}\right]^{3 / 7}-y_{0}
$$

where

$\begin{array}{cl}y_{s} & \text { is the clear-water average contraction scour depth, in feet; } \\ y_{0} & \text { is the average depth in the contracted section before scour, in feet; } \\ Q & \text { is the discharge in the contracted section, in cubic feet per second; } \\ W & \text { is the width (less pier widths) of the of the main channel in the contracted } \\ & \text { section that is transporting sediment, in feet; and } \\ D_{50} & \text { is the median diameter of bed material, in feet. }\end{array}$

\section{Vertical Contraction Scour}

When flow is intercepted by the superstructure of a bridge and, therefore, no longer has a free surface, it undergoes vertical and horizontal contraction. These pressure flow conditions produce additional forces on the streambed and greater stress on the bridge (fig. 4). New bridges are designed with freeboard above the design scour floods to avoid vertical contraction, but some existing bridges are undersized relative to flooding that has occurred since they were designed and built. The 1- or 0.2-percent AEP (or historical) flows produced vertical contraction conditions at eight of the study sites. Vertical contraction scour without overtopping is calculated for live-bed and clear-water conditions using equations 4 and 5, respectively (Arneson and others, 2012 and Shan and others, 2012). The equations are similar to those for horizontal contraction scour, but include a term comparing the depth of flow upstream of the bridge with the vertical opening of the bridge. The second term of both equations represents the estimated thickness of the separation zone, or zone of no flow, that forms under the downstream bridge superstructure ( $t$ in fig. 4). The separation zone further contracts the flow and increases scour. Equations 4 and 5 assume that the flow depth upstream of the bridge is greater than the 


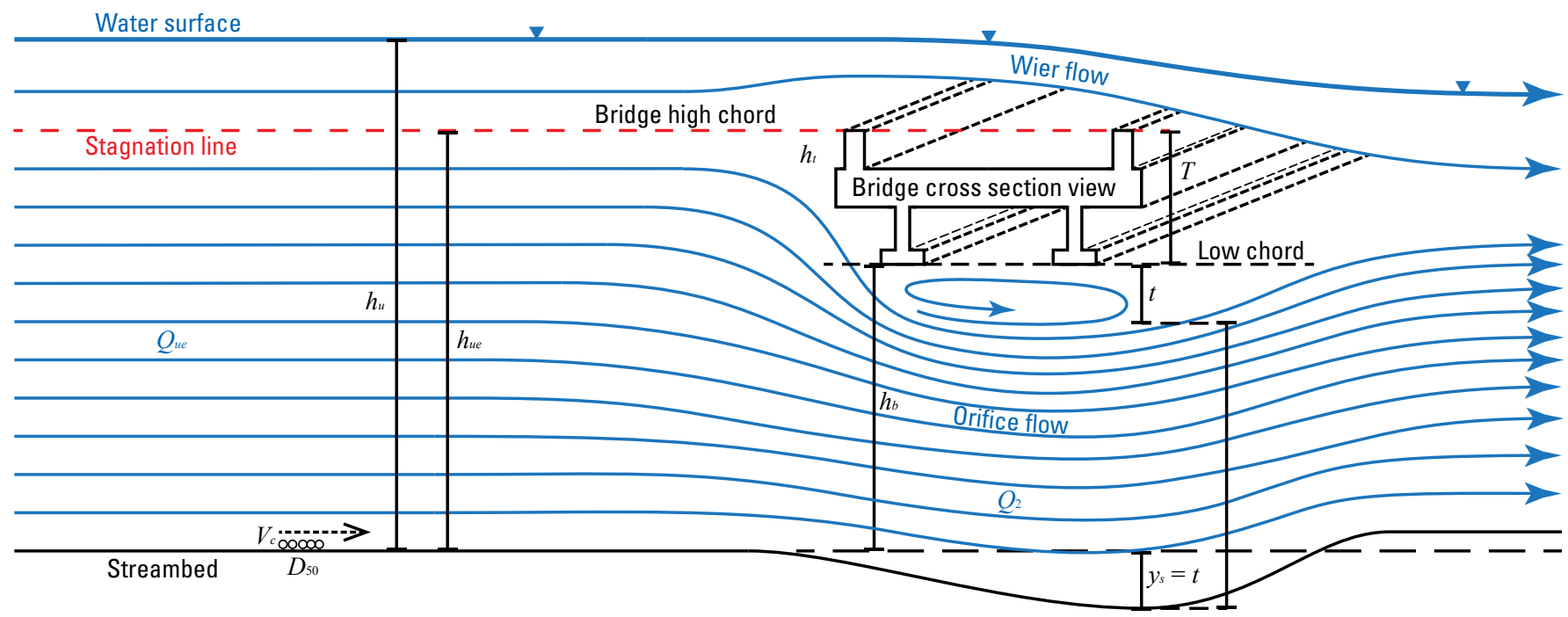

Figure 4. Example of vertical contraction scour and variables used to calculate scour.

flow depth under the bridge (thus vertical contraction occurs). At four sites, scour had already occurred under the bridge, making the second term negative. For these sites, we assumed that the unscoured channel elevation was equivalent to the channel elevation immediately upstream, as with the illustration in figure 4 , and adjusted the bridge opening height $(h b)$ accordingly. One site was overtopped and had weir flow over the deck of the bridge. Equation 6 describes clearwater scour for overtopping situations, where separation zone thickness $t$ is calculated with an additional term to account for the depth of flow over the bridge (eq. 6).

$$
y_{s}=\left[\left(\frac{Q_{2}}{Q_{1}}\right)^{6 / 7}\left(\frac{W_{1}}{W_{2}}\right)^{k_{1}} h_{u}\right]+\left[0.5\left(\frac{h_{b}\left(h_{u}-h_{b}\right)}{h_{u}{ }^{2}}\right)^{0.2} h_{b}\right]-h_{b}
$$

where

$y_{s} \quad$ is the live-bed average vertical contraction scour depth, in feet;

$Q_{1} \quad$ is the discharge in the main channel of the approach section that is transporting sediment, in cubic feet per second;

$Q_{2} \quad$ is the discharge in the contracted section, in cubic feet per second;

$W_{1} \quad$ is the width of the main channel of the approach section that is transporting sediment, in feet;

$W_{2} \quad$ is the width (less pier widths) of the of the main channel in the contracted section that is transporting sediment, in feet;

$h_{u} \quad$ is the average depth in the upstream channel, in feet;

$h_{b}^{u} \quad$ is the vertical size of the bridge opening (low chord to average bed elevation) prior to scour, in feet; and

$k_{1} \quad$ is a coefficient determined by comparing shear velocity to the fall velocity of the $D_{50}$ bed material (see Arneson and others, 2012, p 6.10), which varies from 0.59 to 0.69 .

$$
y_{s}=\left[\frac{0.0077 Q_{2}^{2}}{\left(1.25 D_{50}\right)^{2 / 3} W_{2}^{2}}\right]^{3 / 7}+\left[0.5\left(\frac{h_{b}\left(h_{u}-h_{b}\right)}{h_{u}{ }^{2}}\right)^{0.2} h_{b}\right]-h_{b}
$$


where

$y_{s} \quad$ is the clear-water average vertical contraction scour depth, in feet;

$Q_{2} \quad$ is the discharge in the contracted section, in cubic feet per second;

$W_{2} \quad$ is the width (less pier widths) of the of the main channel in the contracted section, in feet;

$D_{50} \quad$ is the median diameter of bed material, in feet;

$h_{b} \quad$ is the vertical size of the bridge opening (low chord to average bed elevation) prior to scour, in feet; and

$h_{u} \quad$ is the average depth in the upstream channel, in feet.

$$
y_{s}=\left[\frac{0.0077 Q_{2}{ }^{2}}{\left(1.25 D_{50}\right)^{2 / 3} W_{2}^{2}}\right]^{3 / 7}+\left[0.5\left(\frac{h_{b}\left(h_{u}-h_{b}\right)}{h_{u}{ }^{2}}\right)^{0.2}\left(1-\frac{\left(h_{u}-h_{b}-T\right)}{\left(h_{u}-h_{b}\right)}\right)^{-0.1} h_{b}\right]-h_{b}
$$

where

$T \quad$ is the height of the obstruction caused by the bridge superstructure, including the girders, deck, and parapet, in feet.

\section{Pier Scour}

The undermining of bridge piers from scour is a major cause of bridge failure. During floods, piers obstruct flow and cause water to pile up at the upstream end of the pier (fig. 5). This creates horseshoe-shaped vortices that plunge downward around the nose of the pier, scouring bed material from around the base. Scour continues until it reaches an equilibrium depth where the vortices are no longer strong enough to move bed material, similar to contraction scour. Arneson and others (2012) recommended use of equation 7 for most conditions. Tables for each of the correction factors $K_{1}$ to $K_{3}$ are in Arneson and others (2012, chap. 7). Pier scour depends primarily on flow depth immediately upstream of the pier, velocity at the pier, and the width of the pier. Bridges with elongated piers or closely spaced multiple columns are vulnerable to pier scour when the pier is not aligned with the flow direction. This increases the obstruction to flow caused by the pier, similar to increasing the width of the pier. An upper bound for scour depths at cylindrical or round-nosed piers aligned to flow is 2.4 times the pier width (Arneson and others, 2012). Equation 7 does not include the wide pier correction factor $\left(K_{w}\right.$ in Arneson and others, 2012) because no piers met the wide pier criteria, or the effects of armoring by coarse bed material (formerly accounted for with the $K_{4}$ coefficient).

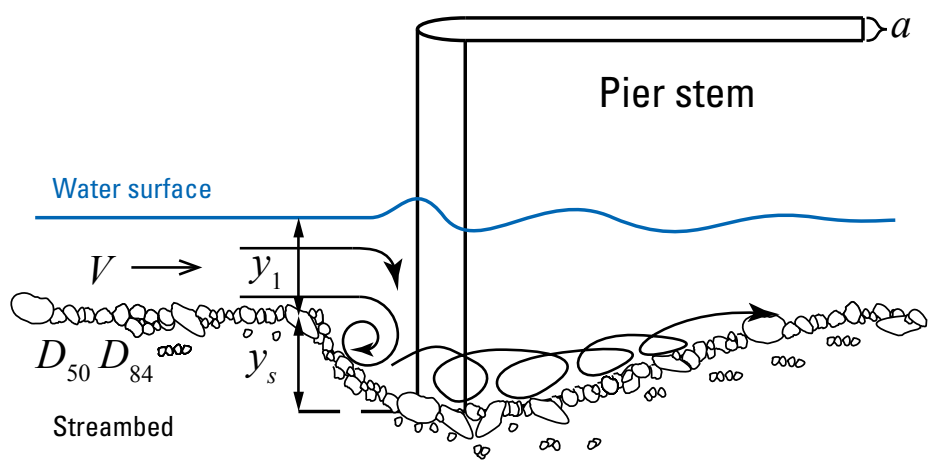

Figure 5. Example of pier scour with variables used to calculate scour. 


$$
y_{s}=2 y_{1} K_{1} K_{2} K_{3}\left(\frac{a}{y_{1}}\right)^{0.65}\left(\frac{V_{1}}{\sqrt{g y_{1}}}\right)^{0.43}
$$

where
$y_{s} \quad$ is the pier scour depth, in feet;
$K_{1} \quad$ is the correction factor for pier nose shape;
$K_{2} \quad$ is the correction factor for angle of attack of flow;
$K_{3}$ is the correction factor for bed condition;
$y_{1} \quad$ is the flow depth directly upstream of the pier, in feet;
$a$ is the pier width, in feet;
$V_{1} \quad$ is the mean velocity directly upstream of the pier, in feet per second; and
$g \quad$ is the acceleration of gravity, 32.2 feet per square second.

\section{Coarse-Bed Pier Scour}

Equation 8 is for the special case of pier scour in clear-water conditions where the $D_{50}$ grain size is $20 \mathrm{~mm}$ or greater and the ratio of $D_{84}$ to $D_{50}$ is 1.5 or greater.

$$
\begin{gathered}
y_{s}=1.1 K_{1} K_{2} a^{0.62} y_{1}^{0.38} \tanh \left(\frac{H^{2}}{1.97 \sigma^{1.5}}\right) \\
H=\left(\frac{V_{1}}{\sqrt{g\left(S_{g}-1\right) D_{50}}}\right) \\
\sigma=\frac{D_{84}}{D_{50}}
\end{gathered}
$$

where

$H \quad$ is the densimetric particle Froude number (eq. 8.1);

$S_{g} \quad$ is the sediment specific gravity (assumed to be 2.65);

$\stackrel{g}{\sigma}$ is the sediment gradation coefficient, must be 1.5 or greater (eq. 8.2); and

$D_{84} \quad$ is the grain diameter of which 84 percent are smaller, in feet.

\section{Pier Scour With Debris}

When debris accumulates on piers, it obstructs flow and may direct flow downward, resulting in additional scour. Arneson and others (2012) recommend doing a debris analysis for bridges with piers and incorporating the effects of debris accumulations in the pier-scour estimate. Of the 11 bridge sites with piers, 5 have noted debris accumulations in ADOT\&PF inspection reports, or had debris on the pier during field surveys. The size and shape (rectangular or triangular) of the debris accumulation are the most important factors influencing the hydraulics around piers with debris. A reasonable debris length, width, and shape for each site were determined using ADOT\&PF site inspection reports and photographs. Equation 9 was then used to calculate an effective pier width $\left(a_{d}^{*}\right)$ to replace $a$ in equation 7 or 8 . 


$$
a^{*}{ }_{d}=\frac{K_{1}(H W)+\left(y-K_{1} H\right) a}{y}
$$

where

$a_{d}^{*} \quad$ is the effective width of a pier with debris present, in feet;

$a$ is the width of the pier, without debris, perpendicular to the flow, in feet;

$K_{1} \quad$ is a debris shape factor ( 0.79 for rectangular debris and 0.21 for triangular debris);

$H \quad$ is the height, or thickness, of the debris, in feet;

$W \quad$ is the width of debris perpendicular to the flow direction, in feet; and

$y \quad$ is the depth of approach flow, in feet.

\section{Complex Pier Scour}

Piers with footings that are exposed to streamflow undergo greater scour owing to complex hydraulics around the footing and pile group (fig. 6). Footings are wider and longer than the area of the pier designed to be in the flow, and when they are exposed to streamflow they have greater hydraulic resistance to flow and can amplify local scour. Bridge 432 over Sawmill Creek and Bridge 607 over Victor Creek have shallow footings, and the complex pier-scour equations were used to evaluate total pier scour (eqs. 10-14). Complex piers are broken down into a pier stem component, a footing component, and a pile group component, which are added together to get total pier scour. Each component is calculated using the basic pier-scour equation 7 , with variables including pier width, depth, and velocity adjusted for each component in a different way. The coefficients $K_{1}, K_{2}$, and $K_{3}$ are determined the same way as in equation 7. Pile cap scour is calculated differently depending on whether the pile cap is above the streambed with an exposed pile group. The pile cap is expected to be undermined at Victor Creek Bridge 607; thus, equation 12 is used to calculate pile cap scour and equation 14 is used to calculated pile group scour. Sawmill Creek Bridge 432 is on a footing with no piles; thus, pile cap scour is calculated using equation 13. Many of the same variables are used in the complex pier equations. Each variable is defined the first time it is used in equations 10-14. Variables shown are applicable to the two sites with complex piers in this study. Slightly different versions of the equations would be used for very wide piers or sand-bedded channels.

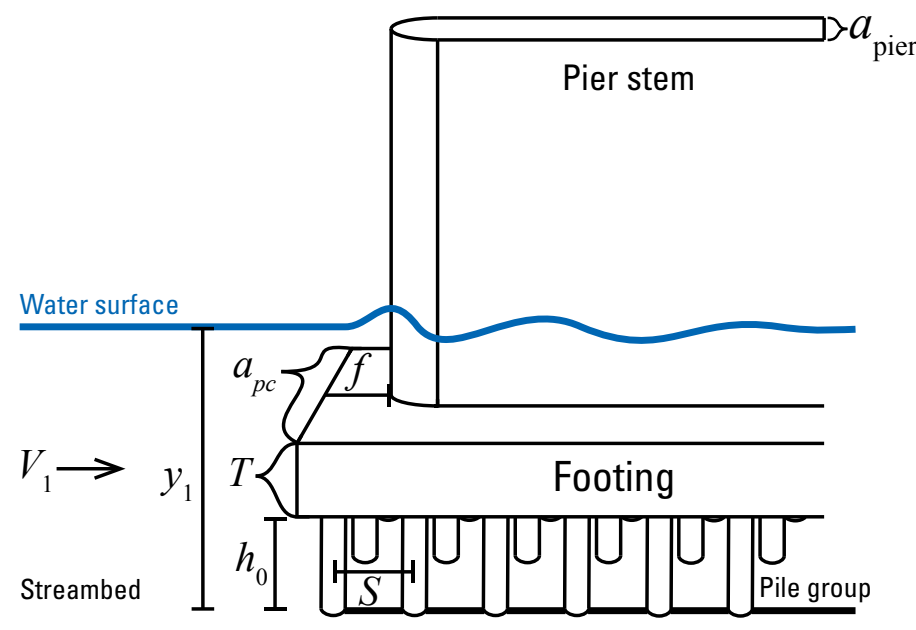

Figure 6. Example of complex pier-scour components and variables used to calculate scour using equations 10-14.7. 
Total Complex Pier Scour

$$
y_{s}=y_{s p i e r}+y_{s p c}+y_{s p g}
$$

where

$y_{s} \quad$ is the complex pier-scour depth, in feet;

$y_{\text {s pier }} \quad$ is the pier-stem scour depth, in feet (eq. 11);

$y_{s p c} \quad$ is the pile cap or footing-scour depth, in feet (eq. 12 or 13); and

$y_{s p g} \quad$ is the pile group scour depth, in feet (eq. 14).

Pier Stem Scour

$$
\begin{aligned}
y_{\text {s pier }}=y_{1} K_{\text {hpier }}\left[2 K_{1} K_{2} K_{3}\left(\frac{a_{\text {pier }}}{y_{1}}\right)^{0.65}\left(\frac{V_{1}}{\sqrt{g y_{1}}}\right)^{0.43}\right] \\
K_{\text {hpier }}=\left(0.4075-0.0669 \frac{f}{a_{\text {pier }}}\right)-\left(0.4271-0.0778 \frac{f}{a_{\text {pier }}}\right) \frac{h_{1}}{a_{\text {pier }}} \\
+\left(0.1615-0.0455 \frac{f}{a_{\text {pier }}}\right)\left(\frac{h_{1}}{a_{\text {pier }}}\right)^{2}-\left(0.0269-0.012 \frac{f}{a_{\text {pier }}}\right)\left(\frac{h_{1}}{a_{\text {pier }}}\right)^{3} \\
h_{1}=h_{0}+T
\end{aligned}
$$

where

$f \quad$ is the distance between the front edge of the pile cap or footing and the pier, in feet;

$a_{\text {pier }}$ is the pier width, in feet;

$h_{0} \quad$ is the pile cap above the bed at the beginning of the calculation, in feet;

$T$ is the thickness of the pile cap or footing, in feet;

$k_{1} \quad$ is the correction factor for the pier nose shape;

$k_{2} \quad$ is the correction factor for the angle of attack of flow;

$k_{3} \quad$ is the correction factor for bed condition;

$y_{1} \quad$ is the approach flow depth at the beginning of the calculation, in feet;

$V_{1}$ is the approach velocity used at the beginning of the calculation, in feet per second; and

$g \quad$ is the acceleration of gravity, 32.2 feet per square second.

Pile Cap Scour (Case 1, Pile Cap above Streambed)

$$
\begin{gathered}
y_{2 p c}=y_{2} 2 K_{1} K_{2} K_{3}\left(\frac{a_{p c}^{*}}{y_{2}}\right)^{0.65}\left(\frac{V_{2}}{\sqrt{g y_{2}}}\right)^{0.43} \\
y_{2}=y_{1}+\frac{y_{\text {spier }}}{2} \cdots\left(y_{2} \leq 3.5 a_{p c}\right)
\end{gathered}
$$




$$
\begin{gathered}
a_{p c}^{*}=a_{p c} e^{\left\{-2.705+0.51 \ln \left(\frac{T}{y_{2}}\right)-2.783\left(\frac{h_{2}}{y_{2}}\right)^{3}+\frac{1.751}{e^{\frac{h_{2}}{y_{2}}}}\right\}} \\
V_{2}=V_{1}\left(\frac{y_{1}}{y_{2}}\right) \\
h_{2}=h_{0}+\frac{y_{\text {spier }}}{2}
\end{gathered}
$$

where

$y_{2} \quad$ is the adjusted depth of flow upstream of the pier, including contraction scour and one-half of the pier stem scour, in feet (eq. 12.1);

$a_{p c}^{*} \quad$ is the adjusted pile cap width, in feet (eq. 12.2);

$a_{p c} \quad$ is the pile cap or footing width, in feet;

$e \quad$ is the natural logarithm base $2.71828 \ldots$;

$V_{2}$ is the adjusted approach velocity approaching the pier, in feet per second (eq. 12.3); and

$h_{2} \quad$ is the adjusted height of the pile cap above the bed after pier scour, in feet (eq. 12.4).

\section{Pile Cap Scour (Case 2 Pile Cap on or below Streambed)}

$$
\begin{gathered}
y_{s p c}=y_{f} 2 K_{1} K_{2} K_{3}\left(\frac{a_{p c}}{y_{f}}\right)^{0.65}\left(\frac{V_{f}}{\sqrt{g y_{f}}}\right)^{0.43} \\
y_{f}=h_{1}+\frac{y_{\text {spier }}}{2} \\
V_{f}=V_{2} \frac{\ln \left(10.93 \frac{y_{f}}{3.5 D_{84}}+1\right)}{\ln \left(10.93 \frac{y_{2}}{3.5 D_{84}}+1\right)}
\end{gathered}
$$

where

ln is the natural logarithm,

$y_{f} \quad$ is the distance from the bed to the top of the footing, after contraction scour and half the pier stem scour, in feet; and

$V_{f} \quad$ is the average velocity in the flow zone below the top of the footing, in feet per second. 
Pile Group Scour for Case of Piles Aligned with Flow

$$
\begin{aligned}
& y_{s p g}=y_{3} K_{h p g}\left[2 K_{1} K_{3}\left(\frac{a_{p g}^{*}}{y_{3}}\right)^{0.65}\left(\frac{V_{3}}{\sqrt{g y_{3}}}\right)^{0.43}\right] \\
& y_{3}=y_{1}+\frac{y_{\text {s pier }}}{2}+\frac{y_{s p c}}{2}\left(y_{3} \leq 3.5 a^{*}{ }_{p g}\right) \\
& K_{\text {hpg }}=\left\{3.08\left(\frac{h_{3}}{y_{3}}\right)-5.23\left(\frac{h_{3}}{y_{3}}\right)^{3}-2.1\left(\frac{h_{3}}{y_{3}}\right)^{4}\right\}^{1.538} \\
& h_{3}=h_{0}+\frac{y_{s p i e r}}{2}+\frac{y_{s p c}}{2} \\
& a_{p g}^{*}=m a K_{s p} K_{m} \\
& V_{3}=V_{1}\left(\frac{y_{1}}{y_{3}}\right) \\
& K_{m}=0.9+0.1 m \\
& -0.0741(m-1)\left[2.4-1.1\left(\frac{S}{a}\right)+0.1\left(\frac{S}{a}\right)^{2}\right] \\
& K_{s p}=1-\frac{4}{3}\left[1-\frac{1}{m}\right]\left[1-\left(\frac{S}{a}\right)^{-0.6}\right]
\end{aligned}
$$

where

$y_{3}$ is the adjusted flow depth for pile group scour (eq. 14.1);

$K_{h p g} \quad$ is the pile group factor (eq. 14.2);

$h_{3} \quad$ is the height of the pile group above the lowered streambed after pier and pile cap scour have been computed in feet (eq. 14.3);

$a_{p g}^{*} \quad$ is the effective width of the pile group in feet (eq. 14.4);

$V_{3} \quad$ is the adjusted velocity for pile group scour in feet per second (eq. 14.5);

$K_{m} \quad$ is the coefficient for number of aligned rows (eq. 14.6);

$m$ is the number of aligned rows;

$S \quad$ is the center to center distance between piles in feet;

$a$ is the diameter of each pile in feet; and

$K_{s p} \quad$ is the coefficient for pile spacing (eq. 14.7). 


\section{Abutment Scour}

Scour at bridge abutments is a common cause of bridge failure, but estimates of abutment scour have been left out of past scour studies because the available equations produced scour estimates that did not agree well with observed scour (Heinrich and others, 2001; Ettema and others, 2010). A study by the National Cooperative Highway Research Program (NCHRP 24-20) resulted in updated methods for estimating scour around abutments and a better understanding of the hydraulics around abutments and approach embankments (Ettema and others, 2010). These methods are now recommended in HEC-18 (Arneson and others, 2012). The NCHRP 24-20 methods treat abutment scour as a local concentration of contraction scour, rather than a separate process. The contraction creates flow separation vortices adjacent to abutments when they encroach on the active flow area (fig. 7; Ettema and others, 2010). The NCHRP 24-20 study also concluded that abutment scour is limited by the geotechnical stability of the embankments, which fail and fill in scour holes when they are undercut. Minor embankment failures are common features of the bridge sites in this study, especially at the nine sites where the embankments were not adequately protected by riprap according to the most recent ADOT\&PF inspection report.

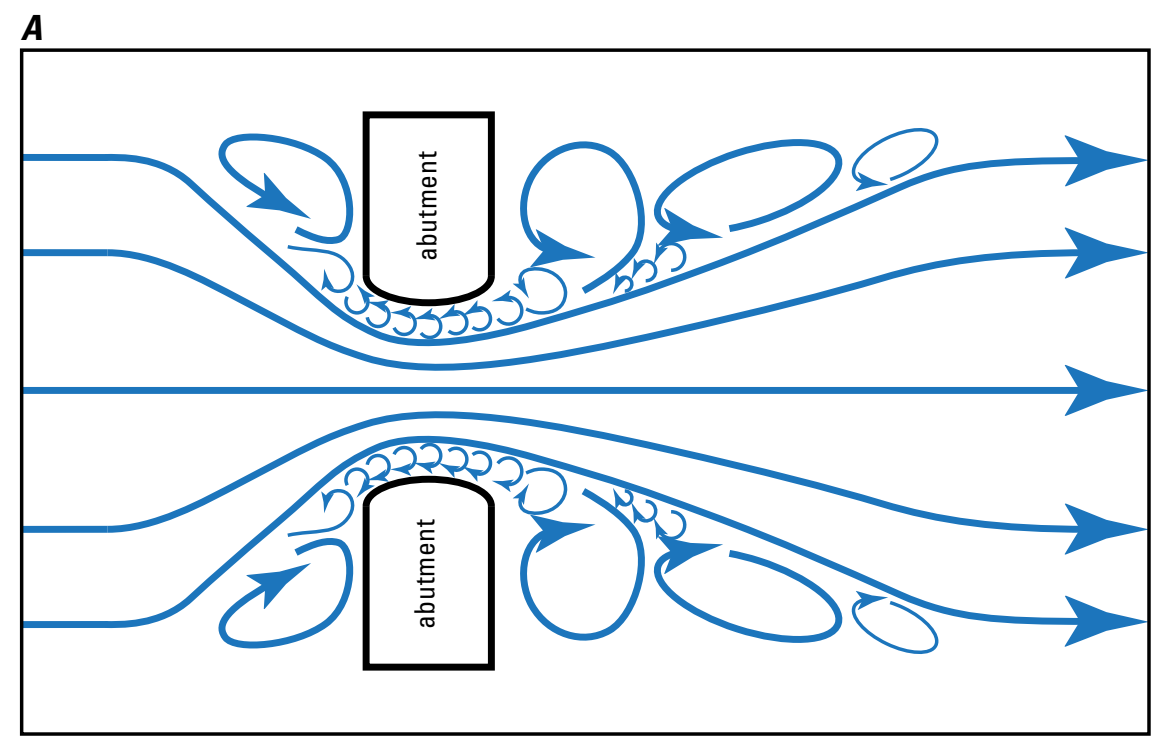

B

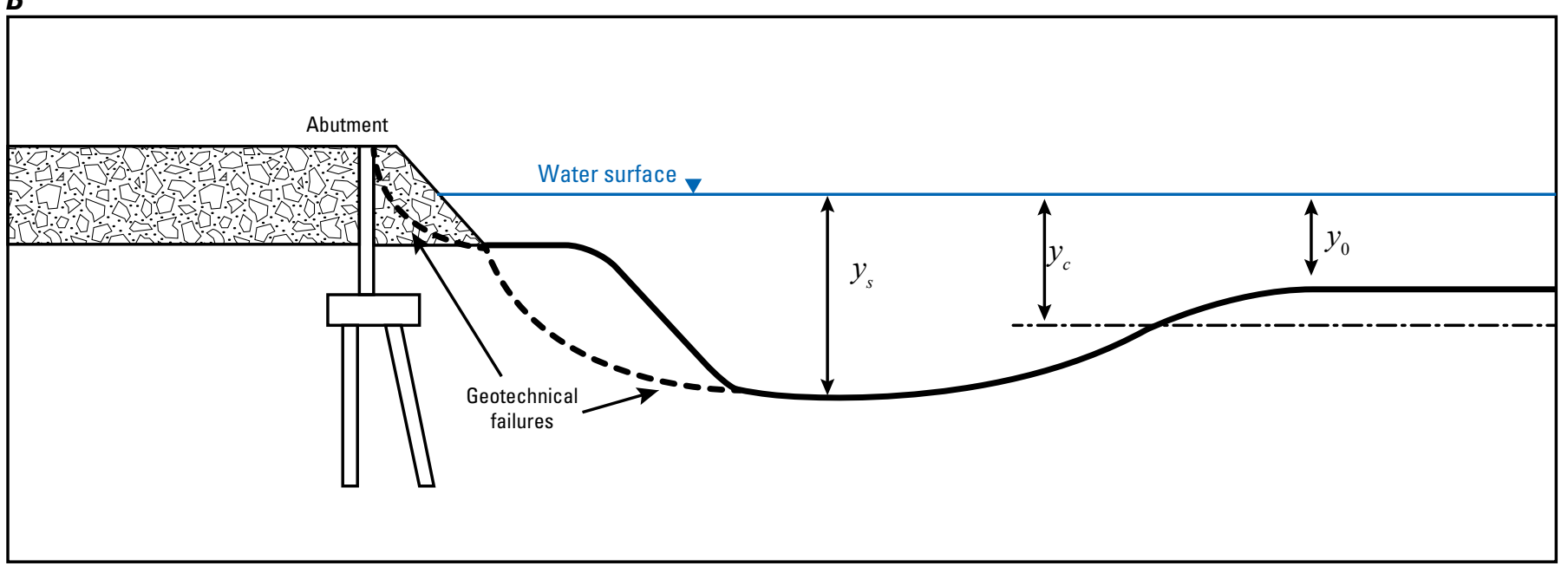

Figure 7. Examples of abutment $(A)$ scour plan and $(B)$ cross-section views. Modified from Ettema and others (2010). 


\section{Streambed Scour Evaluations and Conditions at Selected Bridge Sites in Alaska, 2013-15}

All sites in this study resemble condition A, defined in NCHRP 24-20 as where the abutment is located at or near the main channel. Equation 15 includes an estimate of contraction scour and an amplification factor related to the relative concentration of flow under the bridge for condition A. Arneson and others (2012) suggested using a live-bed equation to calculate contraction scour for condition A, but critical velocity computations show that clear-water contraction scour occurred at several sites. Equation 15 was used with the contraction scour value calculated separately, whether live-bed, clear-water, or vertical contraction equations were used. The amplification factor is determined using figure 8 , which consists of empirically derived curves relating relative contraction $\left(q_{2} / q_{1}\right)$ as calculated in equation 16 to $\alpha_{A}$ for spill-through and wingwall type abutments. The amplification factor peaks for wingwall and spill-through abutments at just under 1.8 and 1.7 when relative contraction is about 1.3 and 1.2, respectively (fig. 8). The physical reason for this is that flow separation dominates the abutment scour process at moderate contraction ratios, whereas contraction scour dominates at higher contraction ratios. Thus, equation 15 will produce large abutment scour estimates for sites with modest contraction and deep channels, regardless of other scour-limiting conditions such as low velocities or bed armoring, or even if the floodwaters do not reach the abutments in the hydraulic model. These cases are flagged as likely overestimates.

$$
y_{s}=\left(\alpha_{A} y_{c}\right)-y_{0}
$$

where

$y_{s} \quad$ is the abutment scour depth, in feet;

$\alpha_{A}$ is the amplification factor for live-bed conditions (fig. 8);

$y_{c} \quad$ is the average flow depth at the bridge including contraction scour, in feet; and

$y_{0}$ is the flow depth at the bridge prior to scour, in feet.

$$
\frac{q_{2}}{q_{1}}=\frac{Q_{1} / W_{1}}{Q_{2} / W_{2}}
$$

where

$q_{1} \quad$ is the unit discharge at the approach cross section, in square feet per second;

$q_{2}$ is the unit discharge at the bridge, in square feet per second;

$Q_{1} \quad$ is the discharge at the bridge, in cubic feet per second;

$Q_{2} \quad$ is the discharge at the approach section, in cubic feet per second;

$W_{1} \quad$ is the flow top width at the bridge, in feet; and

$W_{2}$ is the flow top width at the approach section, in feet. 

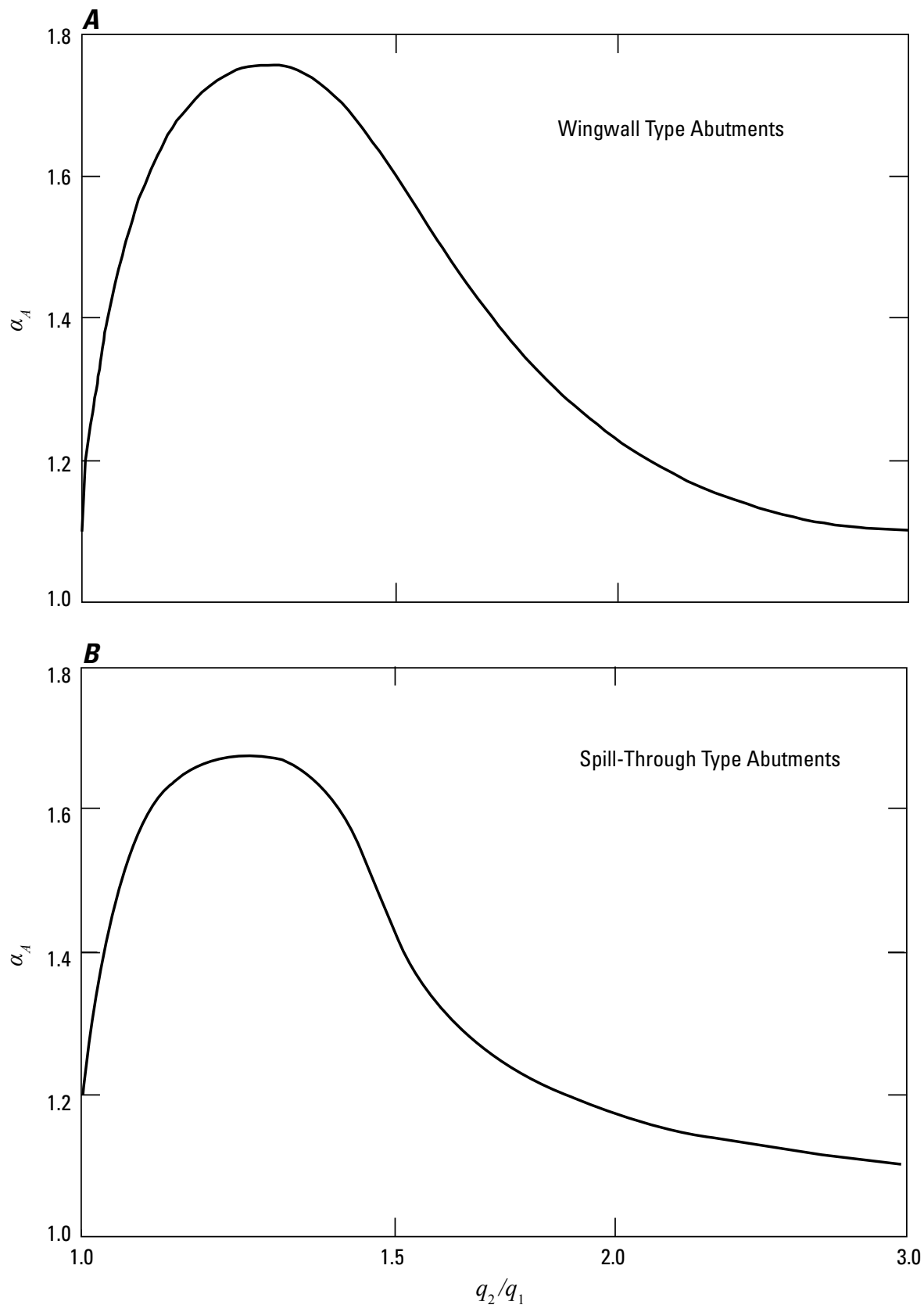

Figure 8. Amplification factor $(A)$ for live-bed abutment scour $\left(q_{2} / q_{1}\right.$, relative contraction) for wingwall $(A)$ and $(B)$ spill-through type abutments. 


\section{Results of Flood Frequency and Scour Assessments}

\section{Flood Frequency Estimates}

Input variables and estimated frequencies for the 1- and 0.2-percent AEP floods are presented in tables 2 and 4 . Table 4 also includes the measured site discharges used for model calibration (labeled "discharge measurement") and any large measured floods that also were used to estimate scour. An example of output from the weighted regression and EMA analysis for Tatlina River is shown in figure 9.

\section{Observed Floods}

A flood greater than the estimated 1-percent AEP flood occurred at six of the bridge sites with nearby streamgages during the period of record:

- Chisana River (424),

- Montana Creek (1669),

- Peters Creek 1501,

- Taiya River (309),

- Tatalina River (462), and

- West Creek (1490).

These bridges were in place at all sites except Montana Creek and West Creek. Hunter Creek did not have a streamgage during the flood of record in 1995, but the bridge in place at the time failed from abutment scour, as did a bridge upstream of Bridge 1501 on Peters Creek.

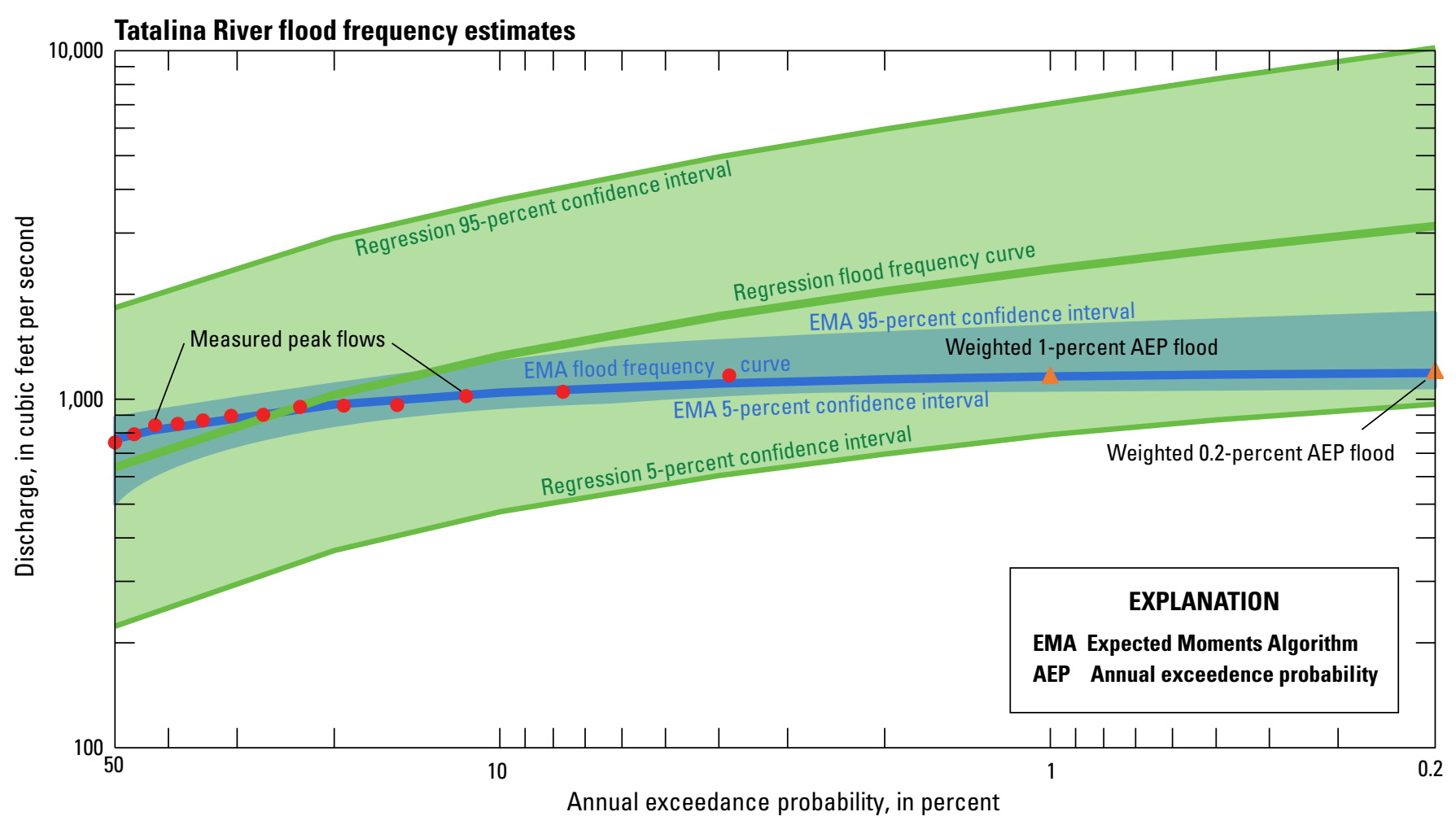

Figure 9. Flood frequency curves used to calculate the weighted 1- and 0.2-percent annual exceedance probability floods, with 5- and 95-percent confidence intervals for each analysis and measured peak flows at Tatalina River near Takotna, Alaska. 
Table 4. Discharges used to estimate scour at selected bridge sites in Alaska.

[All discharge values are in cubic feet per second. Abbreviation and symbol: $\mathrm{ft}^{3} / \mathrm{s}$, cubic foot per second; -, variables that were not used in analysis for that site]

\begin{tabular}{|c|c|c|c|c|c|c|c|}
\hline \multirow{2}{*}{$\begin{array}{c}\text { Bridge } \\
\text { No. } \\
\text { (fig. 2) }\end{array}$} & \multirow{2}{*}{ Stream name } & \multirow{2}{*}{$\begin{array}{l}\text { Discharge } \\
\text { measurement }\end{array}$} & \multicolumn{2}{|c|}{$\begin{array}{l}\text { Annual exceedance } \\
\text { probability discharge }\end{array}$} & \multirow{2}{*}{$\begin{array}{l}\text { Additional } \\
\text { discharge }\end{array}$} & \multirow{2}{*}{$\begin{array}{c}\text { Year of } \\
\text { additional flood } \\
\text { discharge }\end{array}$} & \multirow{2}{*}{$\begin{array}{l}\text { Bridge in place } \\
\text { during flood? }\end{array}$} \\
\hline & & & 1-percent & 0.2 -percent & & & \\
\hline 395 & Alaganik Slough & 474 & 5,920 & 7,310 & - & - & - \\
\hline 433 & Barabara Creek & 56 & 2,680 & 3,640 & 2,050 & 1983 & Yes \\
\hline 2213 & Barney Creek & 24 & 960 & 1,270 & - & - & - \\
\hline 1935 & Bodenburg Creek ${ }^{1}$ & 38 & 62 & 91 & ${ }^{1} 1,500$ & - & - \\
\hline 588 & Boulder Creek & 808 & 540 & 730 & - & - & - \\
\hline 645 & Campbell at Old Seward & 48 & 2,190 & 2,940 & - & - & - \\
\hline 1140 & Chicken Creek & 0 & 660 & 920 & - & - & - \\
\hline 424 & Chisana River & 1,970 & 12,700 & 15,000 & 14,500 & 1997 & Yes \\
\hline 2282 & Coffman Creek & 2.2 & 1,150 & 1,510 & - & - & - \\
\hline 674 & Cooper Creek & 41 & 1,390 & 2,190 & 1,230 & 2003 & Yes \\
\hline 1021 & Crescent Creek & 105 & 1,640 & 2,640 & 1,500 & 1969 & Yes \\
\hline 2283 & Dog Creek & 0.3 & 620 & 820 & - & - & - \\
\hline 2279 & Dog Creek Tidal & 1 & 770 & 1,020 & - & - & - \\
\hline 1463 & Falls Creek & 7.9 & 1,130 & 1,460 & - & - & _- \\
\hline 586 & Flood Creek & 35 & 560 & 780 & - & - & - \\
\hline 1900 & Georges Creek & 4.4 & 340 & 470 & - & - & - \\
\hline 1899 & Georges Creek & 10 & 330 & 460 & - & - & - \\
\hline 445 & Good River & 11 & 3,640 & 4,650 & - & - & - \\
\hline 1821 & Grouse Creek & 16 & 1,350 & 1,960 & 1,160 & 2012 & Yes \\
\hline 578 & Gunn Creek & 262 & 2,640 & 3,460 & - & - & - \\
\hline 590 & Gunny Sack Creek & 65 & 700 & 950 & - & - & - \\
\hline 2264 & Harriet Hunt Creek & 14.1 & 1,190 & 1,540 & - & - & - \\
\hline 3000 & Hatchery Creek & 62 & 5,790 & 7,220 & - & - & - \\
\hline 2129 & Hatchery Creek Tributary & 1.6 & 640 & 850 & - & - & - \\
\hline 844 & Heney Creek & 30 & 870 & 1,130 & - & - & - \\
\hline 1253 & Hunter Creek & 1,536 & 4,330 & 5,560 & - & - & - \\
\hline 1685 & Jordan Creek & 4.4 & 380 & 500 & - & - & _- \\
\hline 893 & Kougarok River & 39 & 1,660 & 2,240 & - & - & - \\
\hline 1713 & Little Susitna River Braid ${ }^{2}$ & 78 & 6,840 & 9,370 & ${ }^{2} 5,450$ & - & - \\
\hline 1717 & Log Jam Creek & 202 & 5,540 & 6,930 & - & _- & - \\
\hline 580 & McCallum Creek & 202 & 1,280 & 1,710 & 1,010 & 1967 & Yes \\
\hline 585 & Michael Creek & 23 & 560 & 760 & - & - & - \\
\hline 1669 & Montana Creek & 1,026 & 13,500 & 18,200 & 15,300 & 1987 & No \\
\hline 1641 & Nataga Creek & 116 & 4,010 & 5,100 & - & - & - \\
\hline 1457 & Newlunberry Creek & 1.8 & 330 & 450 & - & - & - \\
\hline 1018 & North Fork Anchor River & 127 & 1,790 & 2,370 & - & - & - \\
\hline 1409 & Pats Creek & 31 & 1,700 & 2,190 & - & - & - \\
\hline 1501 & Peters Creek & 243 & 4870 & 7,130 & 5,000 & 1995 & Yes \\
\hline 432 & Sawmill Creek & 895 & 15,440 & 15,720 & 11,500 & 2005 & - \\
\hline 1098 & Smith Creek & 15 & 780 & 1,080 & - & - & - \\
\hline 1199 & South Fork Anchor River & 86 & 5,230 & 6,730 & - & - & - \\
\hline 2138 & Swiftwater Creek & 15 & 520 & 700 & - & - & - \\
\hline 309 & Taiya River & 3,756 & 22,000 & 28,100 & 25,000 & 1967 & Yes \\
\hline 463 & Takotna River & 733 & 6,020 & 7,800 & - & - & - \\
\hline 462 & Tatalina River & 60 & 1,170 & 1,210 & 1,170 & 1998 & Yes \\
\hline 584 & Trims Creek & 43 & 760 & 1,010 & - & - & - \\
\hline 1731 & Trocodero Creek & 32 & 1,680 & 2,150 & - & - & - \\
\hline 2281 & Trumpeter Creek & 7.3 & 3,090 & 3,930 & - & - & - \\
\hline 607 & Victor Creek & 141 & 2,550 & 3,260 & - & - & - \\
\hline 1490 & West Creek & 967 & 7,500 & 9,670 & 9,800 & 1967 & No \\
\hline 587 & Whistler Creek & 20 & 390 & 530 & - & - & - \\
\hline 464 & Yankee Creek & 0 & 1,110 & 1,500 & - & - & - \\
\hline
\end{tabular}

${ }^{1}$ Bodenburg Creek is a groundwater-fed stream with very little drainage area, and thus very low predicted floods. See report body text for discussion of overflow flooding.

${ }^{2}$ Little Susitna River Braid is a short distributary channel of the main Little Susitna River. See report body text for discussion of how the design flood was determined. 
Design Floods Other than the 1- and 0.2-Percent Annual Exceedance Probability and Flood Frequency Estimates for Regulated Streams

The design and check floods typically are 1- and 0.2-percent AEP floods, respectively (Arneson and others, 2012). For Little Susitna River Bridge 1713 and Bodenburg Creek Bridge 1935, alternative flood values listed in the "Additional discharge" column of table 4 were used as either the design or check floods. Flood frequency analyses for Cooper Creek Bridge 674 and Sawmill Creek Bridge 432 accounted for site-specific regulation scenarios (table 4).

\section{Little Susitna River Bridge 1713}

Bridge 1713 crosses a sub-channel of the braided Little Susitna River several miles below where the channels diverge. The modeled 1-percent and 0.2-percent AEP floods (6,840 and $9,370 \mathrm{ft}^{3} / \mathrm{s}$, respectively) on the Little Susitna River at Bridge 1713 both substantially overtop the bridge and channel banks. An unknown portion of these flows would occupy other channels in the braid plain. Scour was assessed using the modeled flow that forced the maximum discharge underneath the bridge and created the maximum velocity through the bridge opening. This flow was determined to be $5,450 \mathrm{ft}^{3} / \mathrm{s}$ through iterative modeling with a $250 \mathrm{ft}^{3} / \mathrm{s}$ flow interval. It is unlikely that this great of a proportion of flow would find its way to Bridge 1713, but there is evidence of channel change and flow redistribution elsewhere along the Little Susitna River. Additionally, flows greater than $7,000 \mathrm{ft}^{3} / \mathrm{s}$ have been measured twice upstream.

\section{Bodenburg Creek Bridge 1935}

Bodenburg Creek is a mostly groundwater-fed stream that occupies and abandoned channel linking the Matanuska and Knik Rivers near Palmer, Alaska (fig. 10). It has a small drainage area and estimated 1-percent and 0.2-percent AEP flows of 62 and $91 \mathrm{ft}^{3} / \mathrm{s}$, respectively, although these flows do not include groundwater. However, because of its position on a historical floodplain between two larger rivers, Bodenburg Creek historically has carried much more flow. In August 1971, the Matanuska River breached the Old Glenn Highway and followed Bodenburg Creek to the Knik River. The flow spread significantly, but Lamke (1972) estimated that $1,000 \mathrm{ft}^{3} / \mathrm{s}$ reached the Knik River at the peak from observations and discharge measurement notes. As of 2017, the Matanuska River is eroding the Old Glenn Highway again, so there is a potential for overflow during a flood. Bridge 1935 is located at a relatively narrow part of that flood path (fig. 10), and there is no easy way to constrain the overflow that could go under the bridge. As with Bridge 1713, an iterative approach was used to determine the maximum pressure flow discharge of $1,500 \mathrm{ft}^{3} / \mathrm{s}$.

\section{Regulated Streams}

Two sites, Bridge 674 on Cooper Creek and Bridge 432 on Sawmill Creek, are located downstream of hydroelectric dams that regulate river flow. The dam on Cooper Lake upstream of Bridge 674 captures all inflow to the lake and diverts it through a tunnel to Kenai Lake. The lake level is regulated to avoid spill over the spillway, and no spill has occurred (other than testing of the spillway) since the dam was completed in 1962 (Chugach Electric Association, 2005). The flood frequency analysis assumed that the basin upstream of the lake outlet would not contribute to floods downstream at the bridge. The regression analysis used the basin downstream of the lake outlet to calculate flood frequency, and the EMA analysis used the post-dam peak flows recorded at USGS streamgage 15261000 near Bridge 674.

Sawmill Creek below Blue Lake Dam is a more complicated case. The Blue Lake Hydroelectric Dam was built between 1958 and 1961, and was expanded in 2012. Blue Lake spills annually during high-flow periods. Stream gaging records from 1921 to 1957, before the dam was built, show a different flood regime than those after the dam was built. The highest measured pre-dam flood was $7,100 \mathrm{ft}^{3} / \mathrm{s}$. The highest measured post-dam flood was $11,500 \mathrm{ft}^{3} / \mathrm{s}$ in 2005. Two floods estimated to be $12,000 \mathrm{ft}^{3} / \mathrm{s}$ in 1972 and 1993 are reported in Federal Energy Regulatory Commission (FERC) licensing documents (City and Borough of Sitka Electric Department, 2010). An EMA analysis for the preand post-dam periods show significantly different results (fig. 11). The 1-percent AEP flood varies from 8,700 ft $\mathrm{ft}^{3} / \mathrm{s}$ using pre-dam peak flows to $16,990 \mathrm{ft}^{3} / \mathrm{s}$ using post-dam peak flows. However, the maximum spillway capacity at Blue Lake Dam is $14,000 \mathrm{ft}^{3} / \mathrm{s}$ and the FERC licensing documents suggest that the dam is operated in order to regulate spill during floods (City and Borough of Sitka Electric Department, 2010). The 1- and 0.2-percent AEP floods used in this analysis consist of the $14,000 \mathrm{ft}^{3} / \mathrm{s}$ maximum spillway flood added to the maximum powerhouse output of $520 \mathrm{ft}^{3} / \mathrm{s}$, and the respective regression-analysis-derived flood numbers for the drainage basin below Blue Lake. 


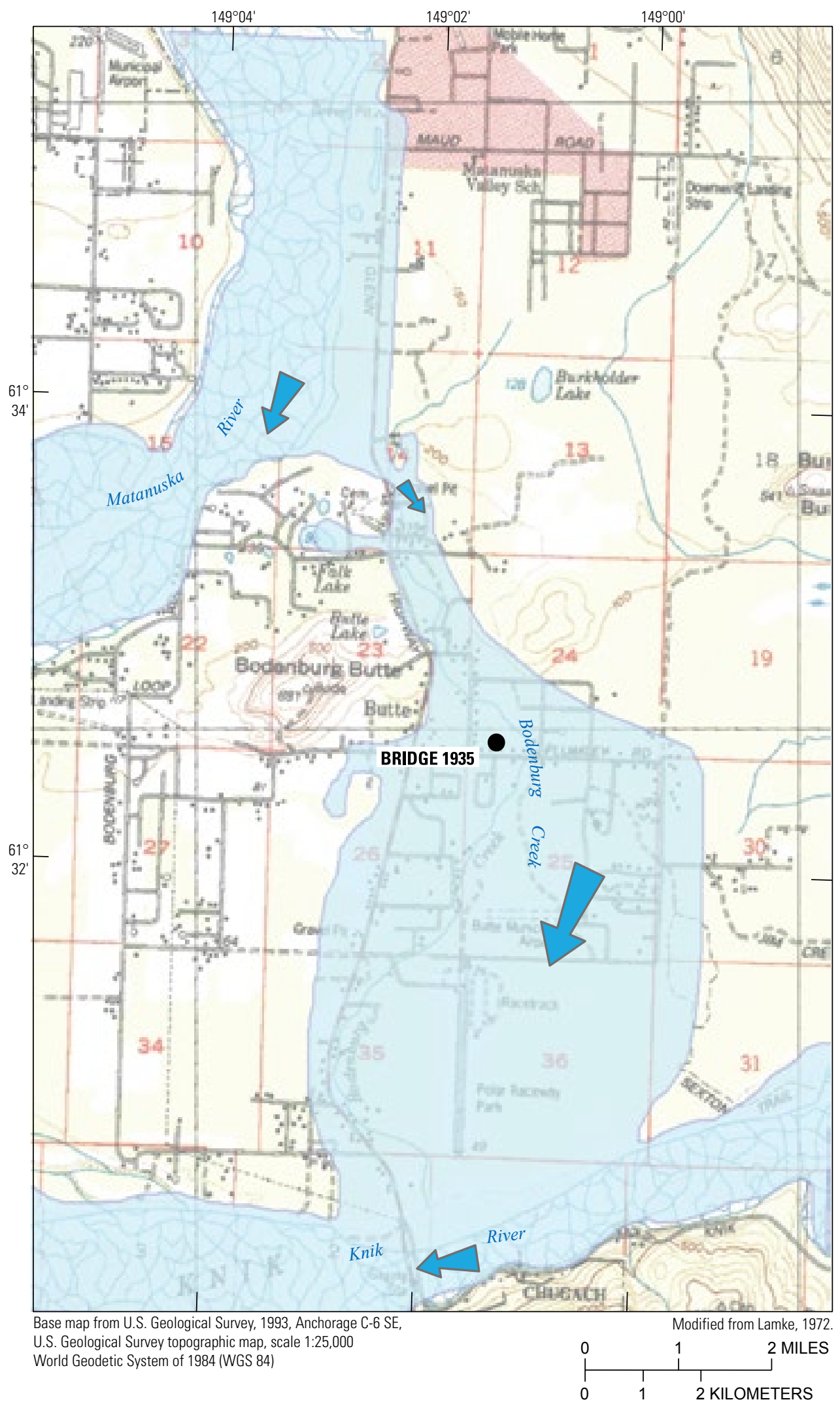

Figure 10. Bodenburg Creek overflow during floods in south-central Alaska, August 1971. 


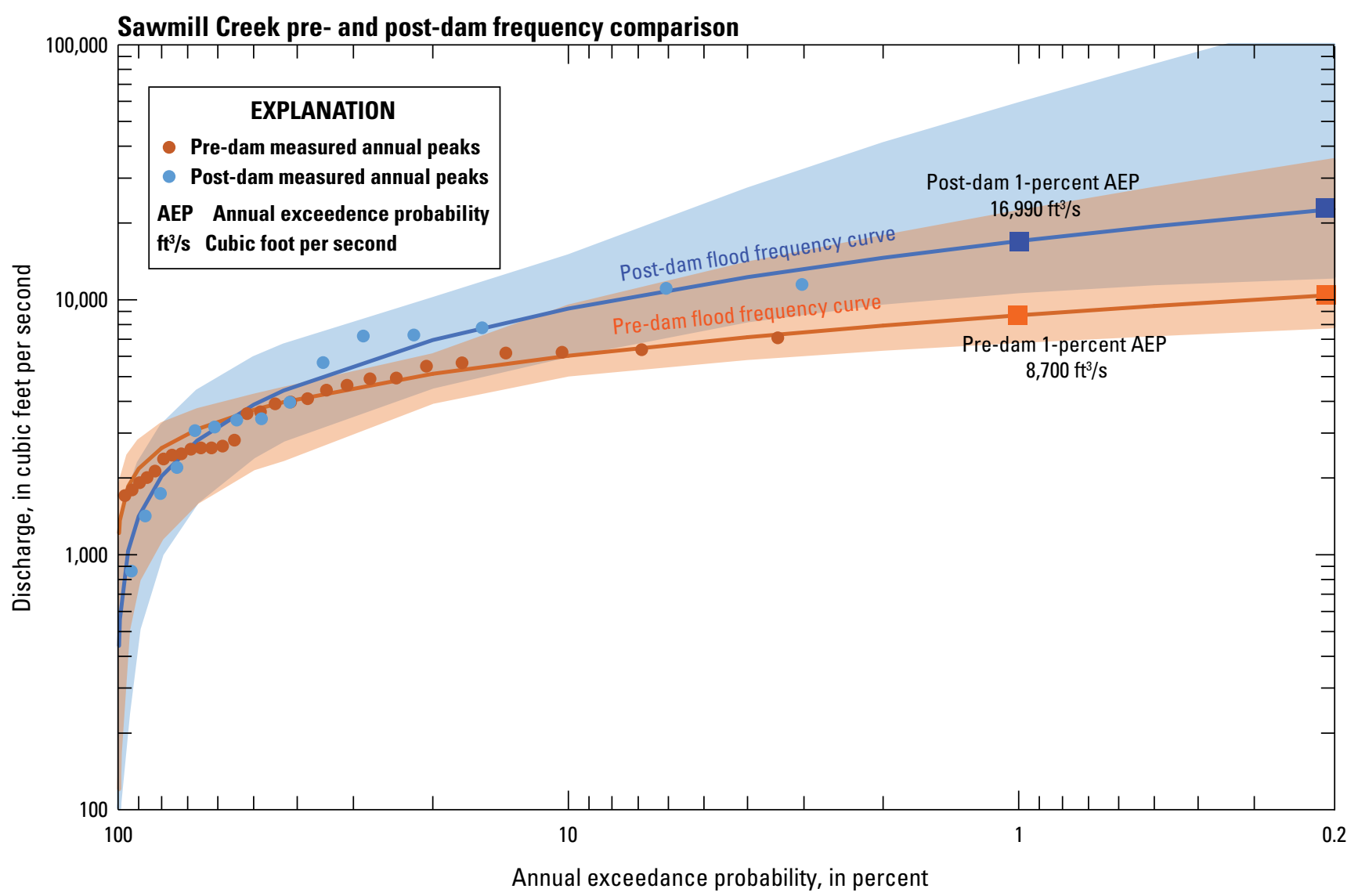

Figure 11. Flood frequency curves for the pre- and post-dam periods at Sawmill Creek near Sitka, Alaska.

\section{Stream Stability and Geomorphic Assessment}

Stream stability at the reach scale was assessed using geomorphic observations and sounding records (table 5, fig. 12). With the exception of bedrock-dominated Newlunberry Creek Bridge 1457, all sites are at least partially alluvial with streambeds and banks composed of sediment, and thus have the potential to shift, erode, or aggrade if disturbed. However, most of the sites are classified as stable or moderately stable, with little evidence of reach-scale channel change, significant sediment sources, or human disturbance beyond road embankments or bank stabilization. Moderately unstable sites showed evidence of active sediment sources and natural channel change. Unstable sites - which have active sediment source areas, evidence of channel change, and human disturbance-include 10 sites on active alluvial fan landforms, 1 site with an active tributary fan just upstream of the bridge, 1 site with active in-channel mining, and 1 site with a shifting tributary confluence just upstream of the bridge. Most sites have more than 10 years of sounding data, whereas 9 of the 52 sites have 5 or fewer years of sounding data. All of these nine sites are classified as stable based on the short available record, and most of them are in geomorphically stable settings; however the short record reduces confidence in the results.

Evidence for geomorphic or anthropogenic instability did not always correspond to variation in streambed elevations in the sounding record. However, of the 10 least stable sites from the sounding record, 8 sites were on active alluvial fans with evidence of significant geomorphic instability, and 1 site was actively mined. Three additional alluvial fan sites were classified as "less stable" (figs. 12 and 13). Where channel geometry is unstable, scour evaluations (which rely on a model of the static channel) have a larger margin of error than those for stable channels. Instability also can contribute to scour by increasing the flow angle of attack on piers and abutments and redirecting flow to road approaches. 


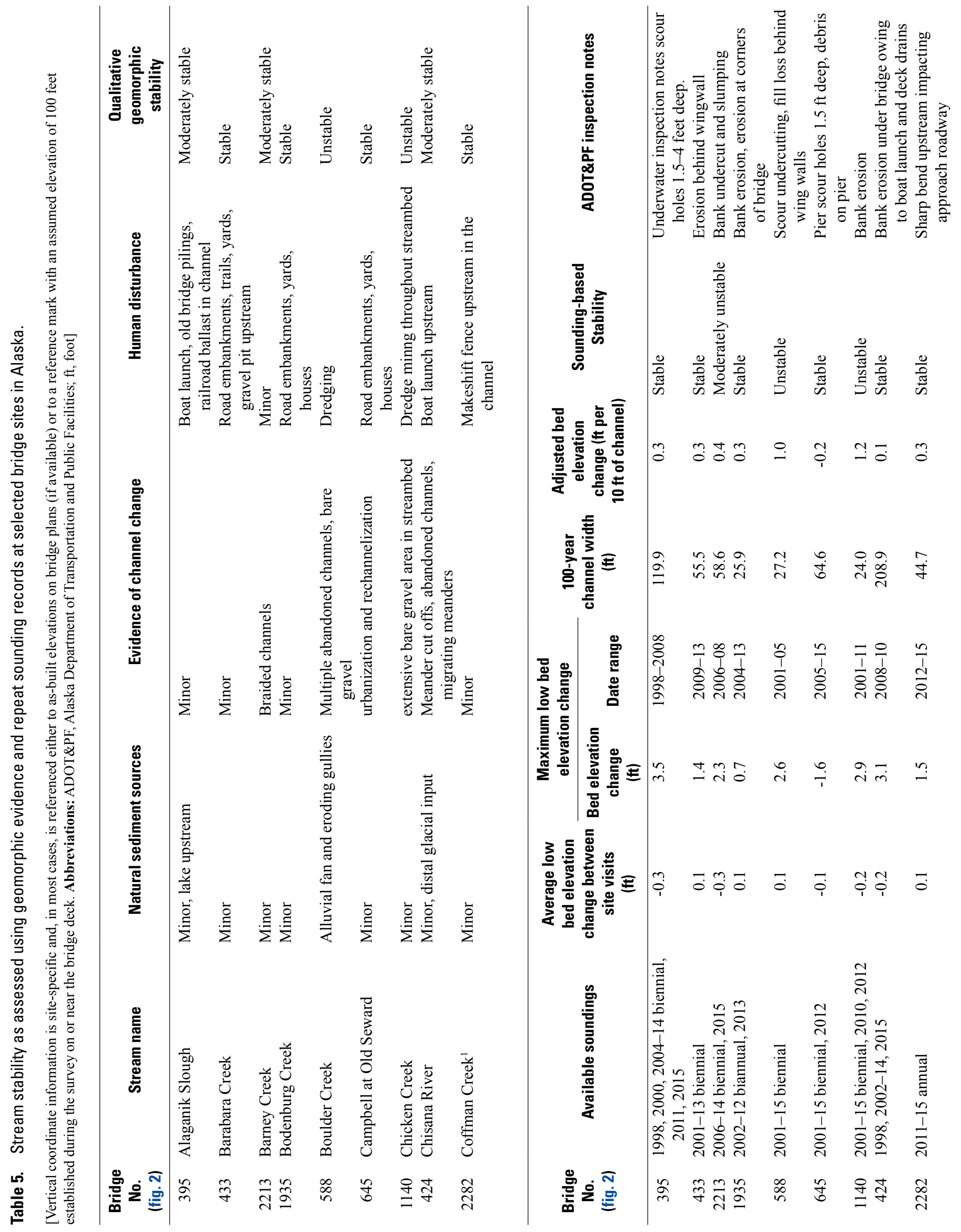



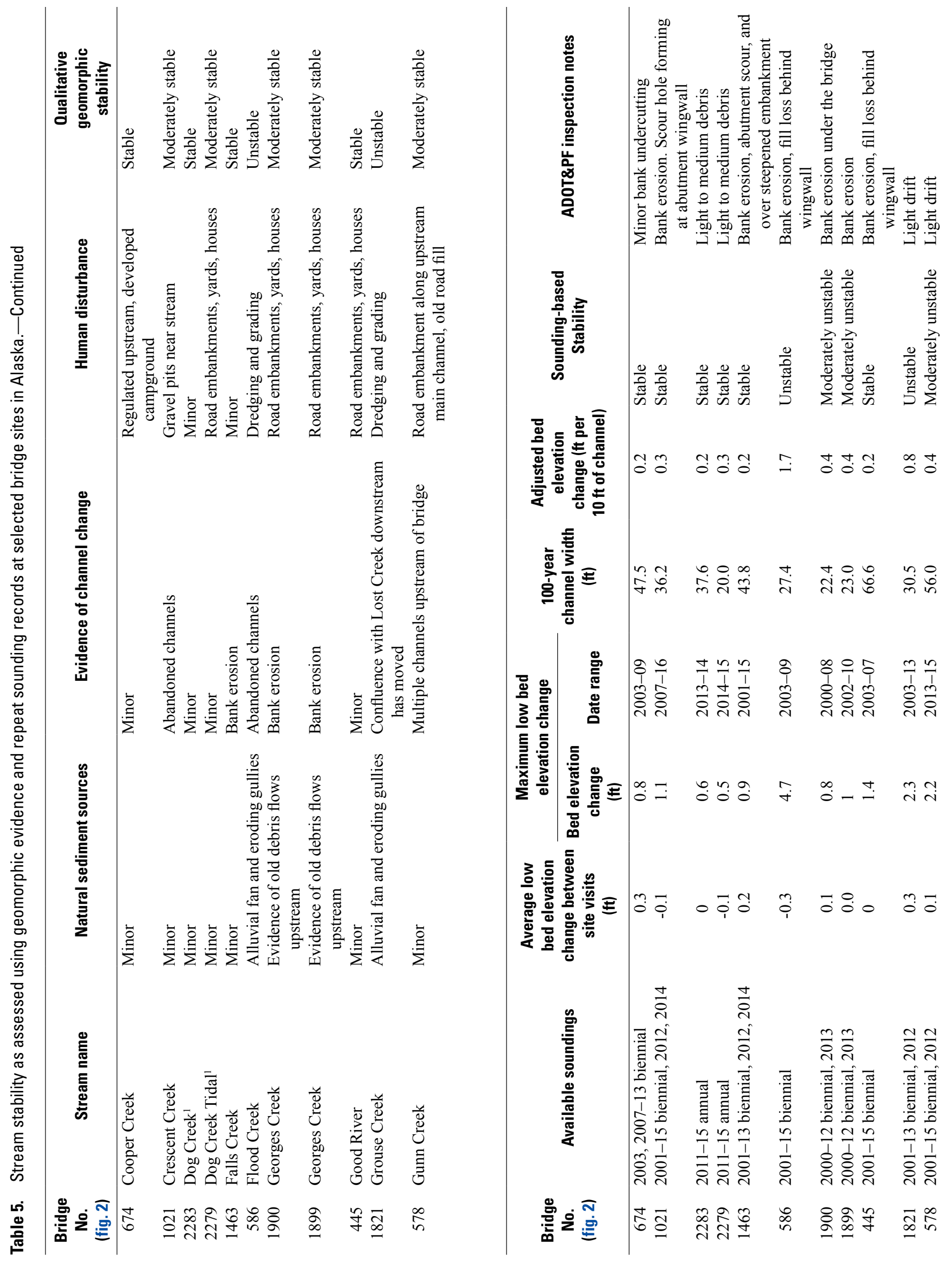


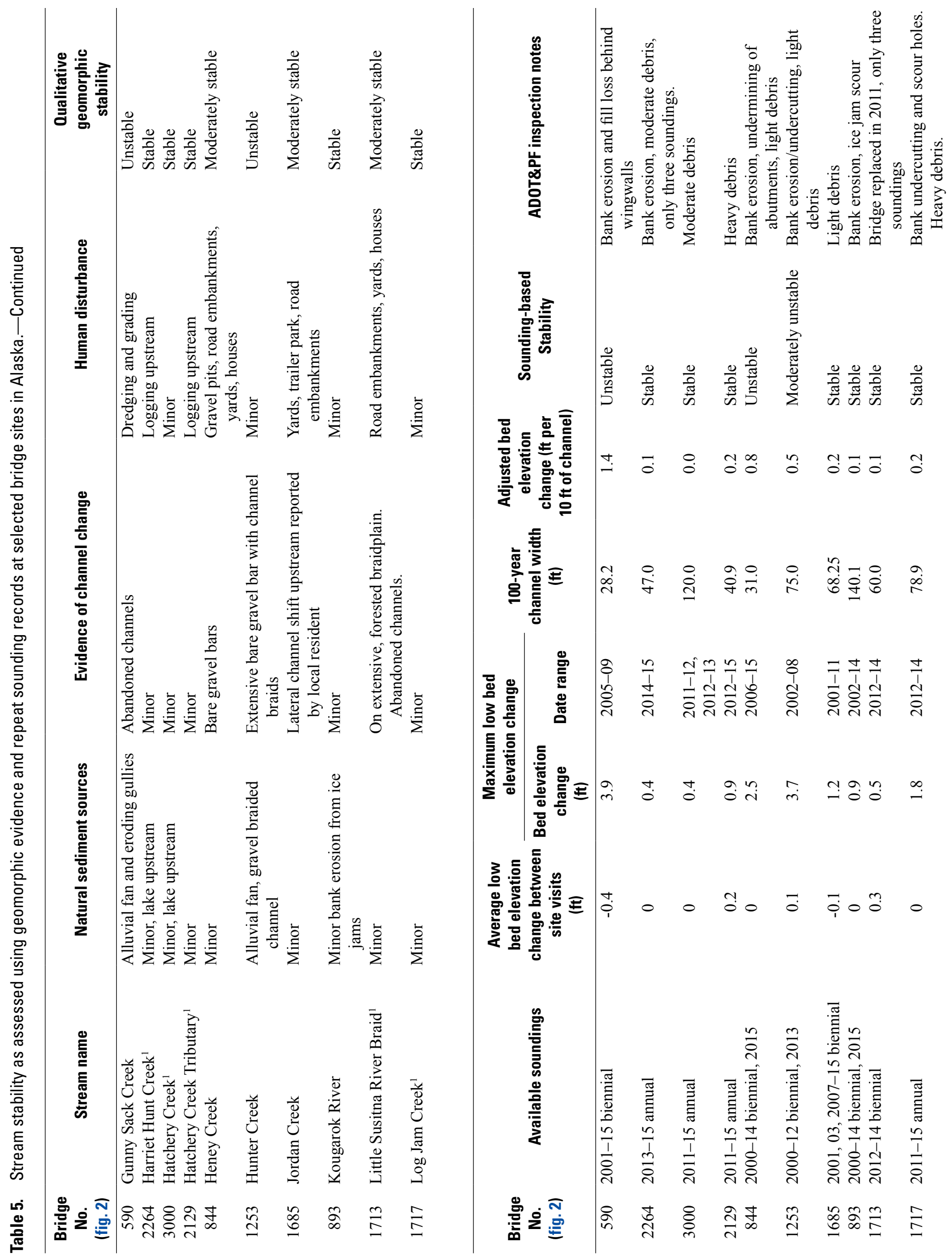




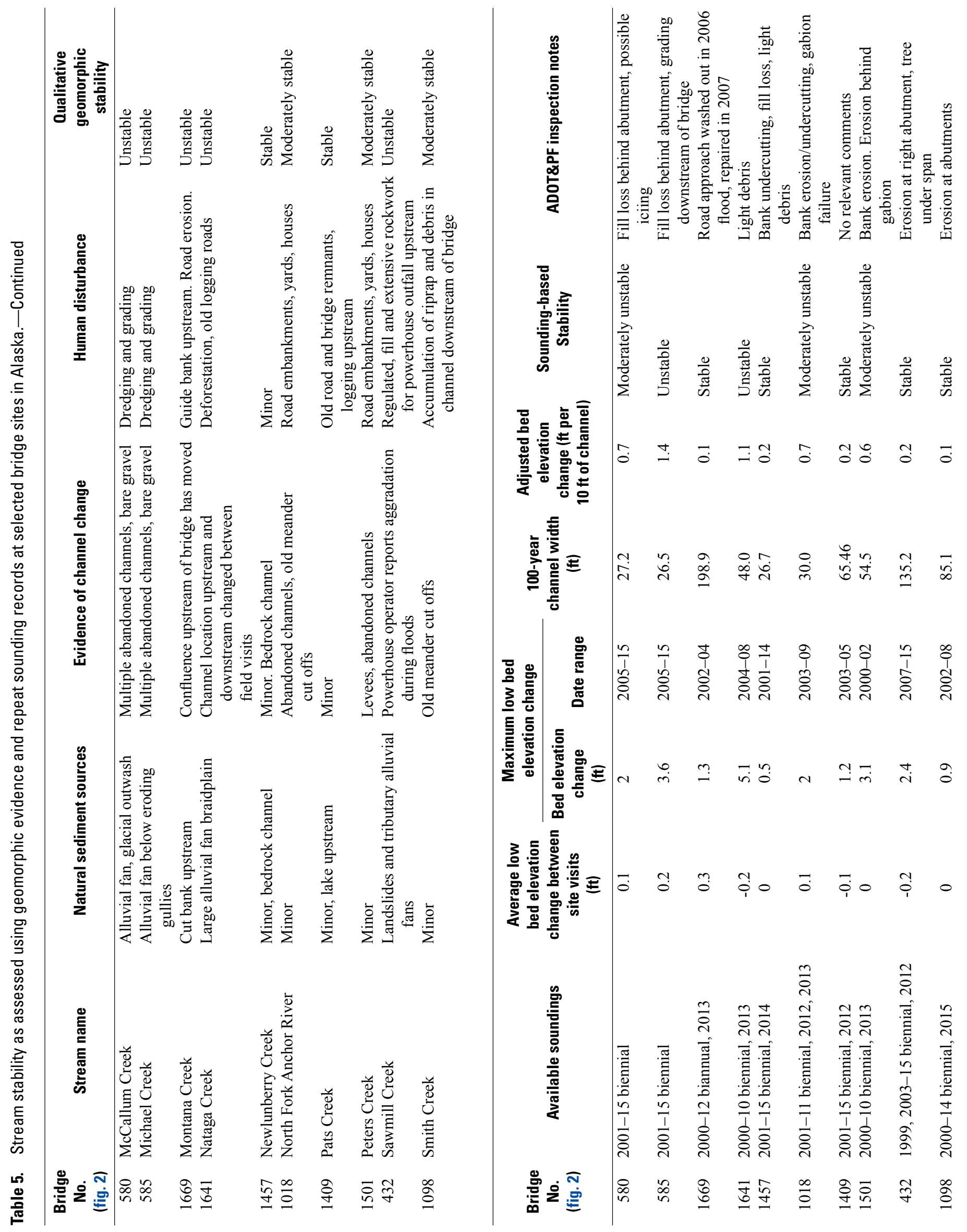



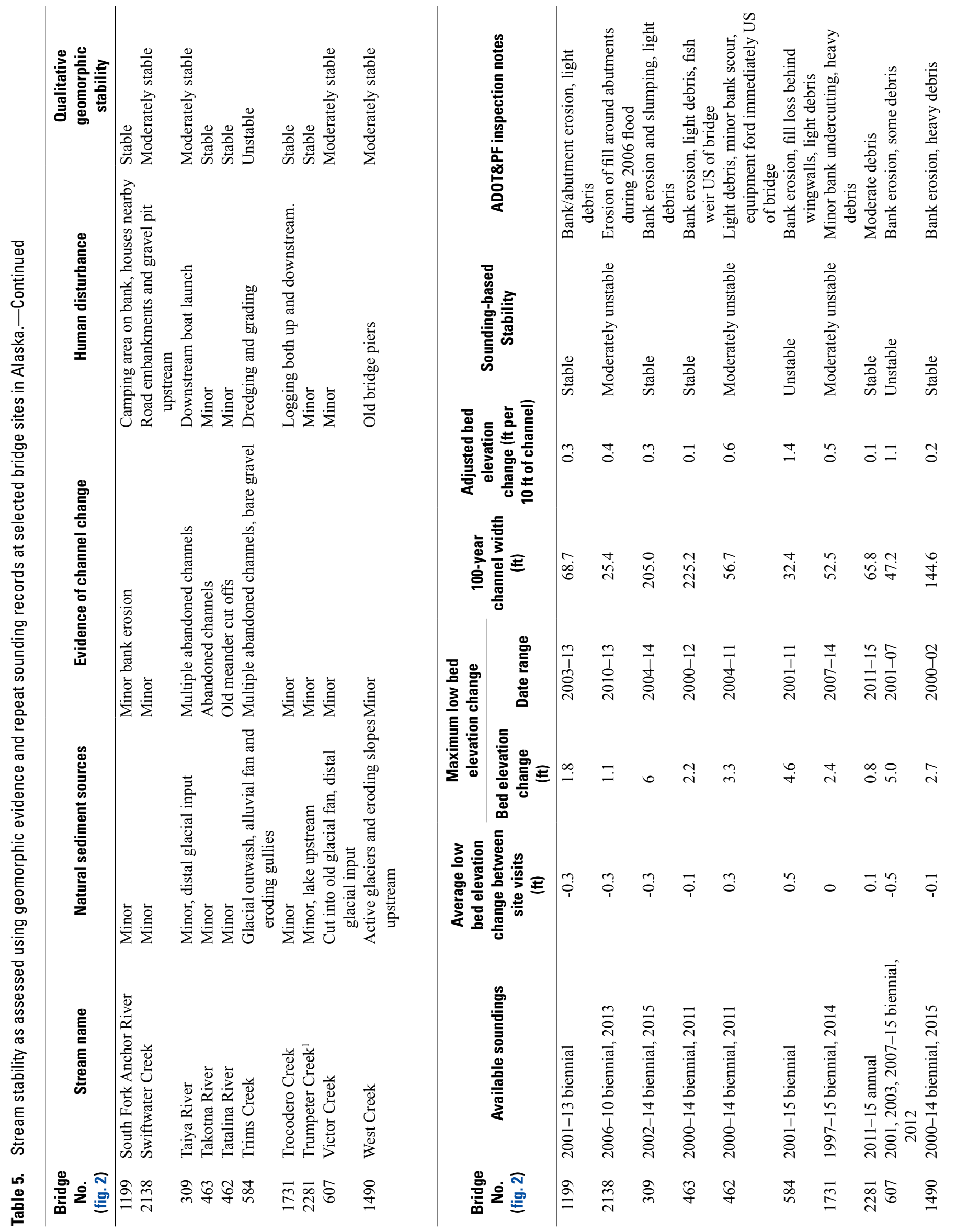


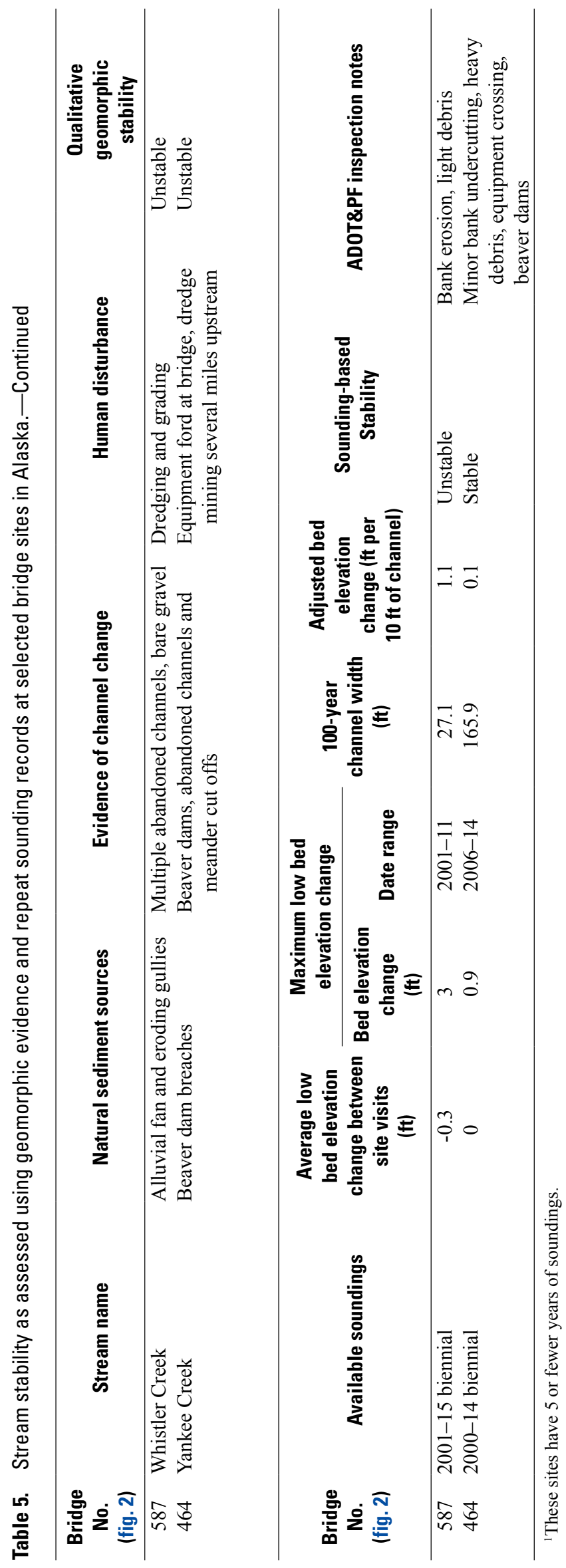




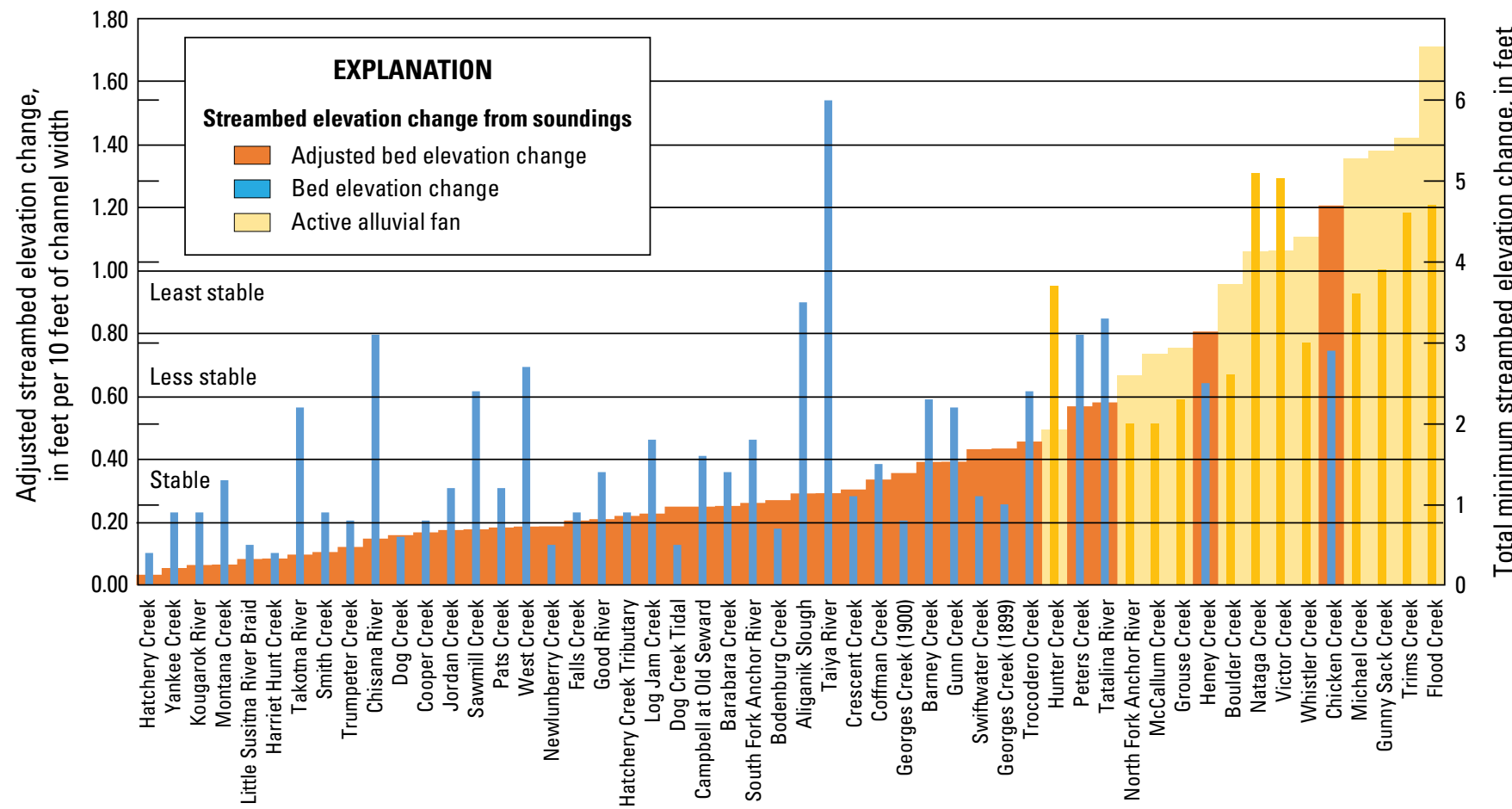

Figure 12. Sounding-based stream stability at 52 river- and stream-spanning bridges in Alaska.

Soundings did not show definitive signs of either long-term aggradation or degradation at any study sites, although evidence for degradation at Victor Creek is presented in section, "Unstable Sites-Victor Creek Bridge 607." The average change in minimum bed elevation between successive soundings was less than or equal to $0.5 \mathrm{ft}$ at all sites. Most sites had $0.1 \mathrm{ft}$ or less cumulative change. However, numerous sites on alluvial fans showed evidence of dredging, which typically is done to combat aggradation and would prevent aggradation from appearing in the sounding record.

Repeat cross-section soundings are useful in identifying instabilities but cannot be used to rule out vulnerability to scour or other responses to flooding. Scour and fill often are short-lived and are evident only during and shortly after a flood (Conaway, 2007). Soundings taken at 2-year intervals, even if a flood occurs between soundings, may not indicate the transient effects of the flood on the channel cross section. Some bridges have only $3-5$ years of soundings. Short sounding records are less likely to capture long-term trends or responses to infrequent flood events. All measured cross sections for study sites are in appendix 1.

\section{Unstable Sites}

\section{Alluvial Fan Channels along the Richardson Highway}

Seven of the 52 sites in this study are located on outwash fans of tributaries to the Delta River:

- McCallum Creek Bridge 580,

- Trims Creek Bridge 584,

- Michael Creek Bridge 585,

- Flood Creek Bridge 586,

- Whistler Creek Bridge 587,

- Boulder Creek Bridge 588, and

- Gunny Sack Creek Bridge 590. 

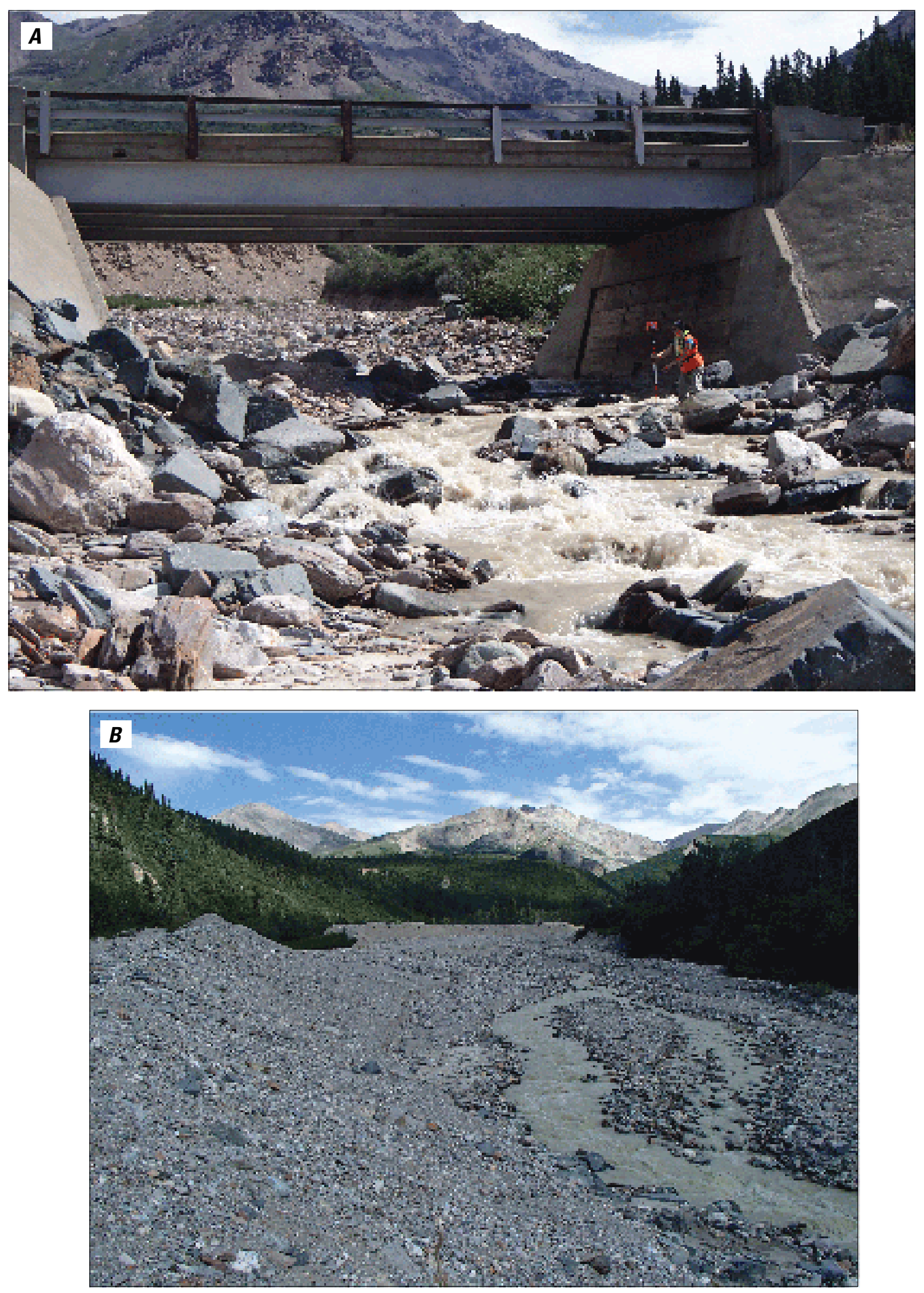

Figure 13. "Less stable" alluvial fans at $(A)$ Gunny Sack Creek Bridge 590 and $(B)$ Whistler Creek upstream of Bridge 587, Alaska. 
The Richardson Highway crosses these fans near the upper or middle part of the depositional area. The Trans-Alaska Pipeline crosses underneath each stream about $500 \mathrm{ft}$ downstream of the highway. All these channels are geomorphically unstable, and instability is reflected in the sounding record for all but McCallum Creek. All these streams are relatively steep and high velocity, and are composed of cobble and boulder beds (fig. 13). Boulder weirs are used to prevent trenching at the pipeline crossing, and guidebanks or simple berms are used to stabilize channels at the bridge. The risk of catastrophic contraction or abutment scour at these sites is minimized by high sedimentation rates, grade control downstream, and armoring in the bridge channel. The most common problems are fill loss around the abutment wingwalls, which are steep and subject to high velocities and contraction-related flow separation during floods. Aggradation during a flood also could lead to overtopping of the road approaches and more rapid abutment loss.

\section{Chicken Creek Bridge 1140}

Chicken Creek Bridge 1140 is perennially destabilized by dredge mining and in-stream grading to combat aggradation caused by floods. If the channel is lowered downstream, this instability could lead to scour. However, the dominant regime at Chicken Creek seems to be aggradation.

\section{Victor Creek Bridge 607}

Victor Creek Bridge 607 seems to be degrading based on visual inspection, according to 1952 as-built plans (hereinafter referred to as "as-builts"), and soundings since 1999. The as-builts show a low streambed of $475 \mathrm{ft}$. The first sounding record available in 1999 shows a low streambed of $467.6 \mathrm{ft}$. After a regional flood in 2006 (Victor Creek is ungaged), the minimum streambed dropped to $464.5 \mathrm{ft}$, and as of $2015 \mathrm{had}$ increased to $465.6 \mathrm{ft}$. Although the visible streambed is mostly cobbles, gravel, and boulders, as-builts indicate that at an elevation of $465 \mathrm{ft}$ and below the streambed is composed of firm gravelly silt that probably has some cohesive properties. The footing is exposed to flow and significantly affects pier-scour estimates. In addition to channel degradation, ADOT\&PF has noted bank erosion in most inspection reports. Scour at the site has either reached an equilibrium since the bridge was built, or armoring and cohesive properties of the firm gravel noted in the as-builts have limited degradation below an elevation of $465 \mathrm{ft}$.

\section{Nataga Creek Bridge 1641}

Bridge 1641 crosses Nataga Creek on an alluvial fan about $200 \mathrm{ft}$ upstream of the confluence with the Kelsall River. Nataga is a steep, cobble-bedded creek flowing through a
200 -ft-wide braidplain. The active channel moved from the far left side of the braidplain to the far right side between July and October 2013. Fresh debris in 2014 indicated that the stream had moved across the braidplain recently again. Soundings indicate more than $5 \mathrm{ft}$ of vertical change in the low streambed, which is significant given that there is, on average, less than $10 \mathrm{ft}$ of vertical distance between the low chord and the stream bed. The instability at Nataga Creek likely will continue and may lead to abutment or approach road loss.

\section{Heney Creek Bridge 844}

Heney Creek Bridge 844 does not appear to be geomorphically unstable or destabilized by human activity. However, the sounding record shows changes in bed elevation. Inspection photographs show a large gravel bar upstream of the bridge, and the main channel occupying either side or the middle of the gravel bar in different years. In 2015, the main channel was split into two channels with the gravel bar in the middle, and the two channels met at the sounding location. The instability seen in the repeat soundings may relate to the upstream channel shifting around the gravel bar and is not indicative of a reach-scale problem.

\section{Scour Calculations}

\section{Contraction, Abutment, and Pier Scour}

Clear-water and live-bed scour estimates for 49 sites with horizontal contraction scour at the design and (or) check floods where the water surface did not reach the low chord of the bridge are shown in table 6. These estimates range from no scour to a maximum of $3.7 \mathrm{ft}$, and are split about evenly between live-bed and clear-water conditions, although both estimates are shown for each site. Vertical contraction scour is predictably higher, as much as $8.0 \mathrm{ft}$ for the design and (or) check floods at eight bridges where the water surface reaches the low chord (table 7). Abutment scour, which is treated as an amplification of contraction scour, ranges from 0.3 to $13.1 \mathrm{ft}$ (table 8).

Pier scour and total scour at piers (pier scour plus contraction scour) are listed in table 9 for eleven bridges with simple piers, in table 10 for two bridges with complex exposed foundations, and in table 11 for three bridges with coarse beds and clear-water conditions. Pier scour ranged from 0.1 to $8.9 \mathrm{ft}$, before adding contraction scour. Pier scour with debris was calculated for five bridges with debris accumulation noted in site visits. Debris increased pier scour by an average of $2.5 \mathrm{ft}$. All scour estimates (contraction, abutment, and pier) for each bridge are summarized in table 12 . 


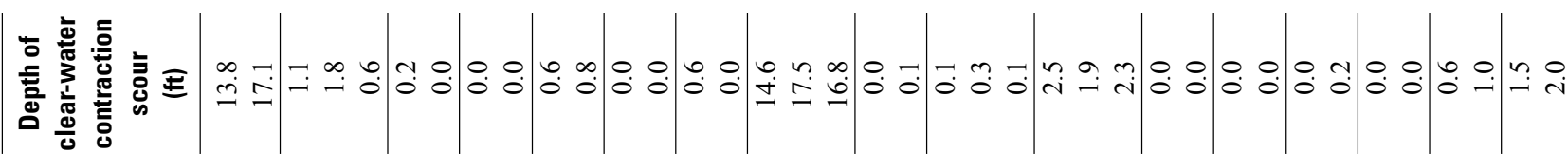

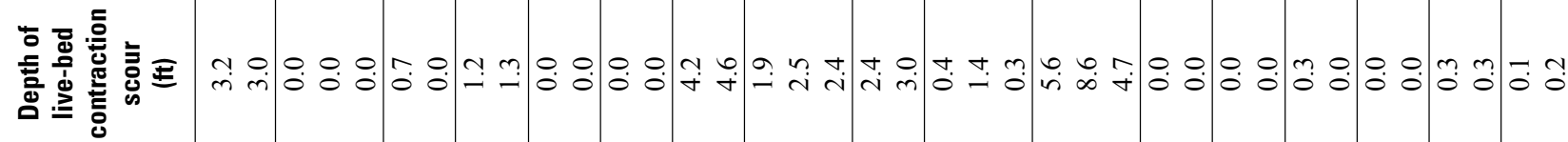
产言

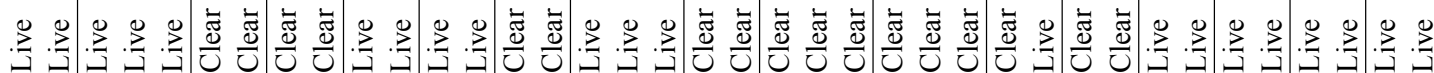

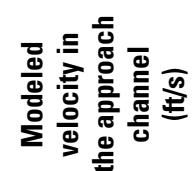

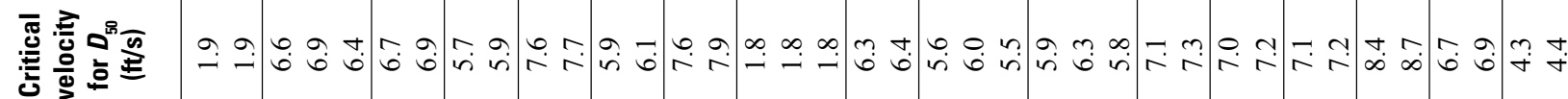
0 :

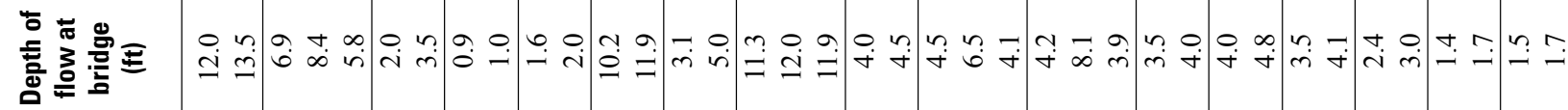

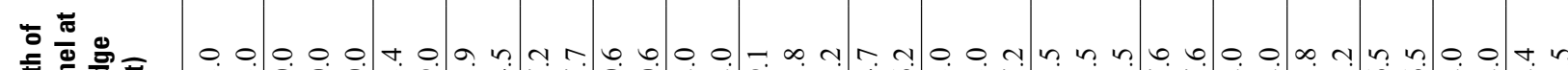

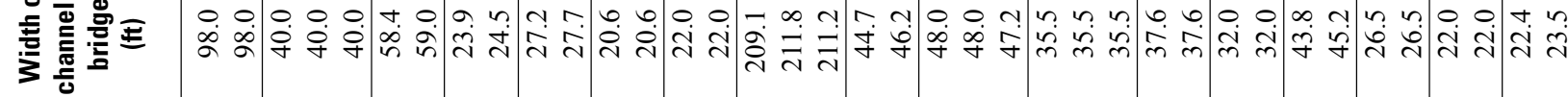

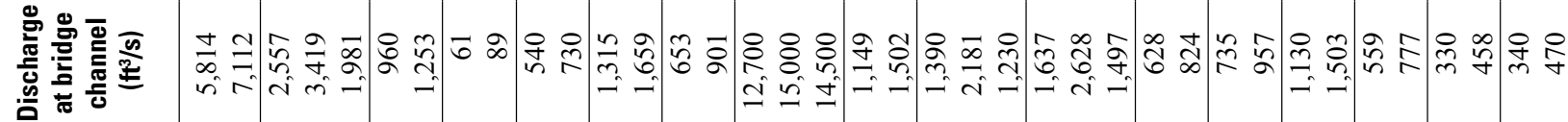

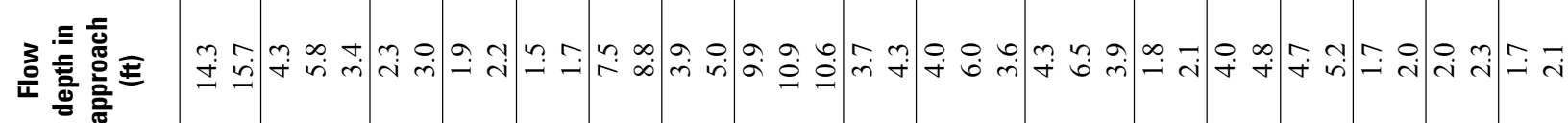

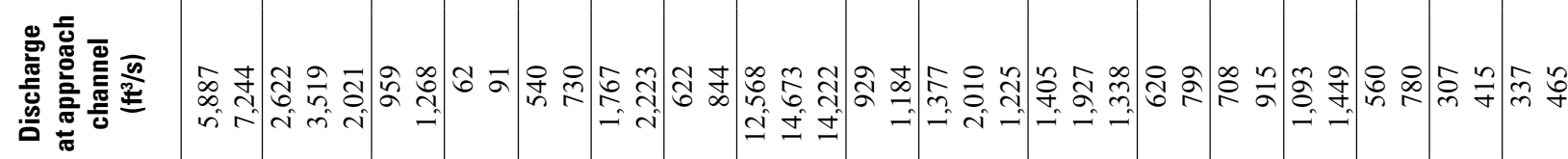

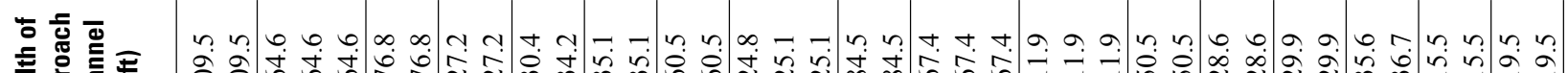

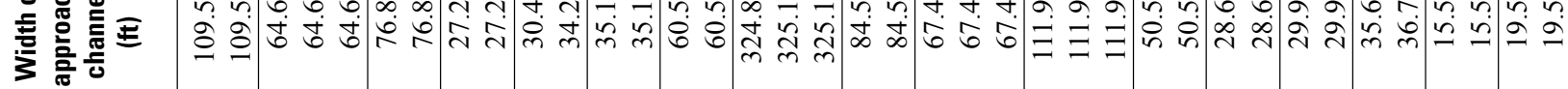

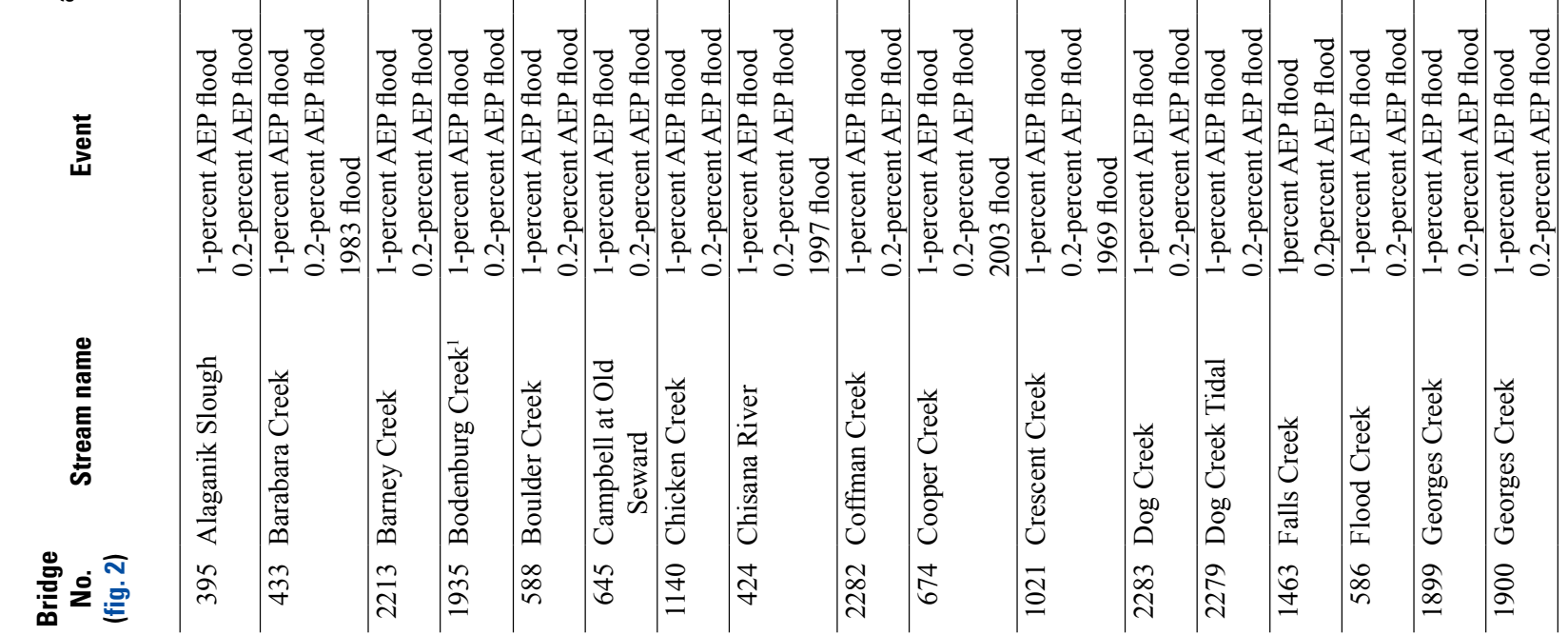




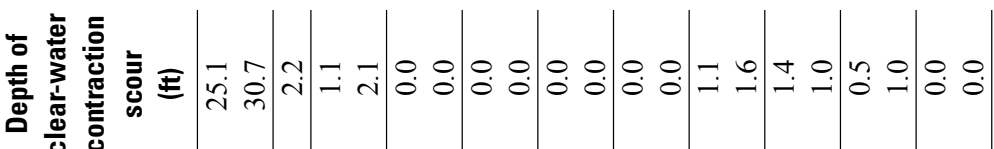

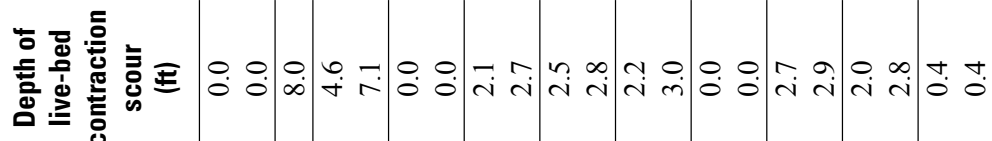
产言

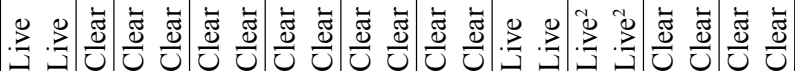

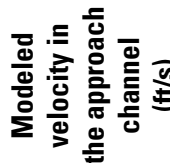

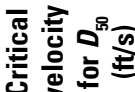

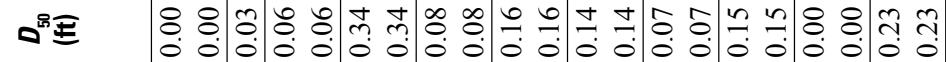

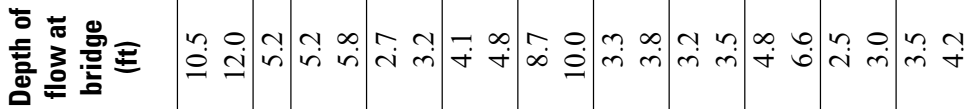

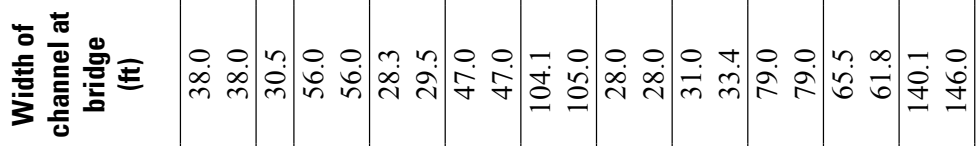

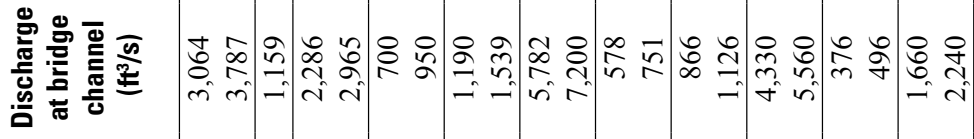

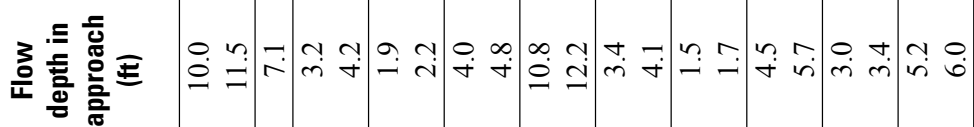

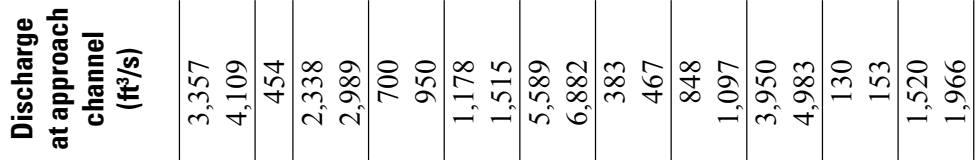

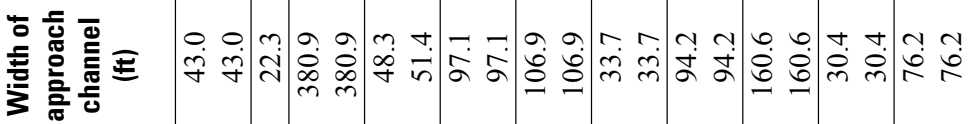

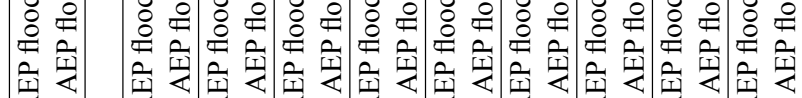

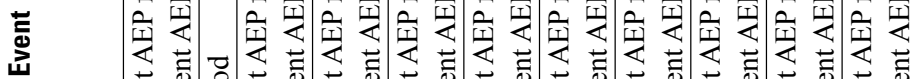

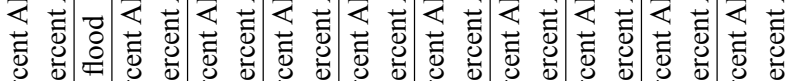

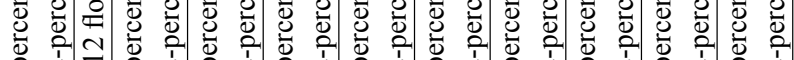

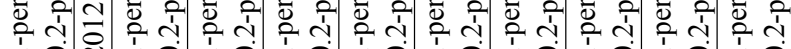

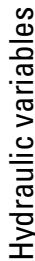

$\frac{\omega}{\frac{0}{a}}$

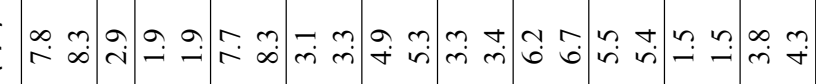

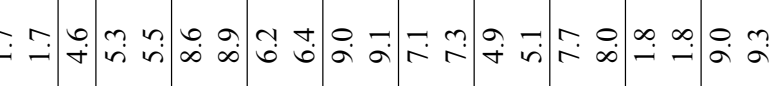

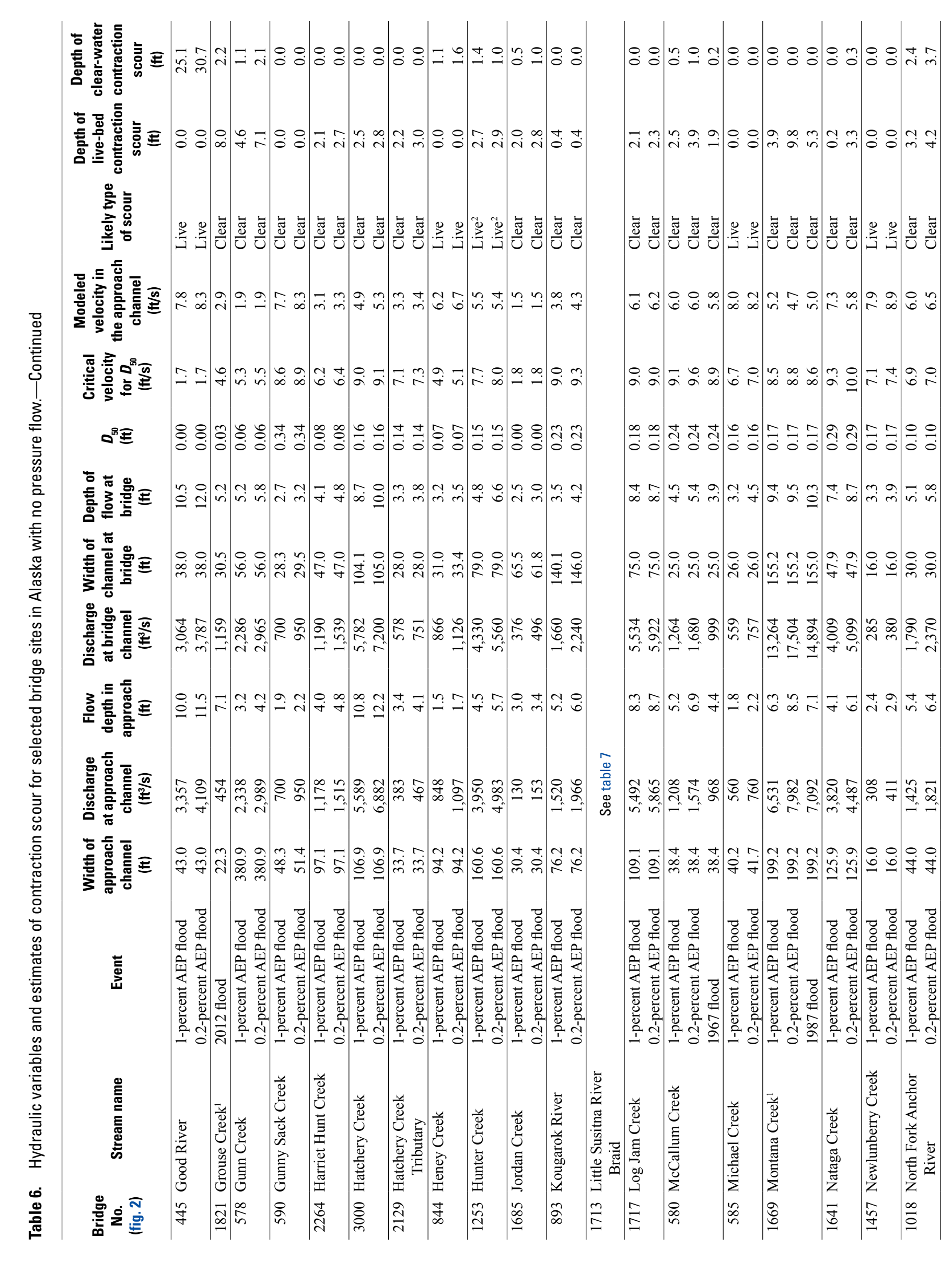

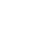




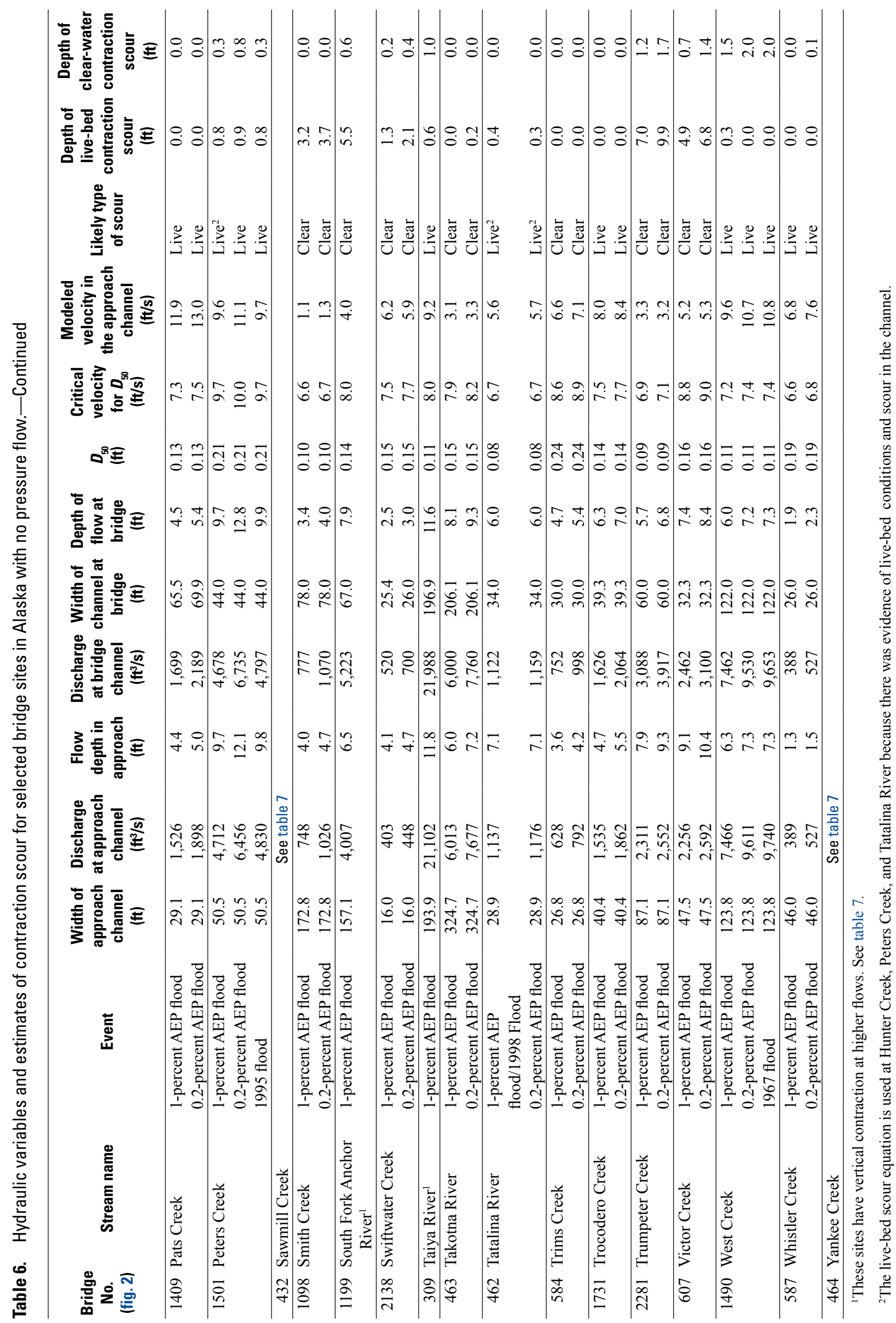



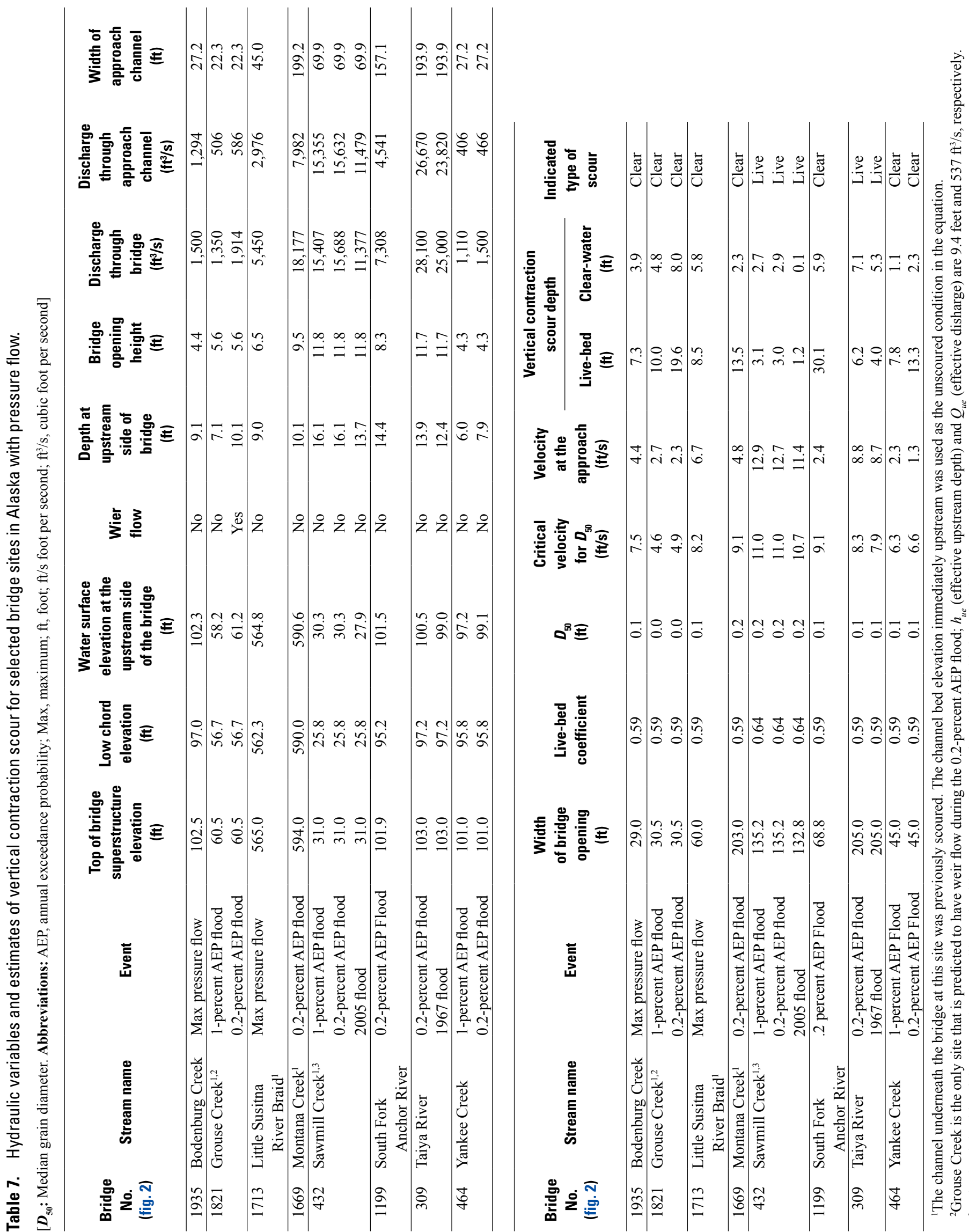

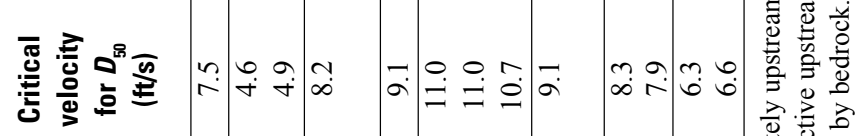

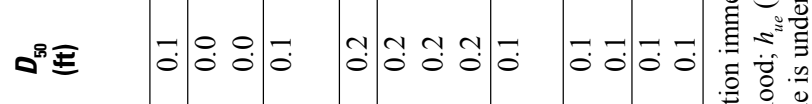

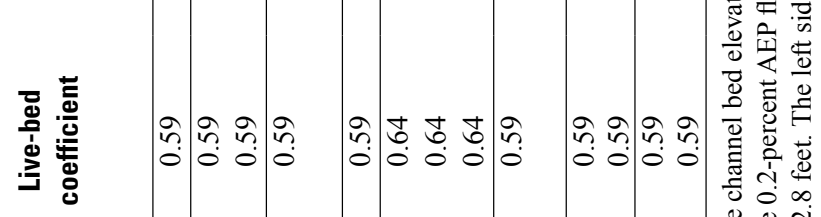

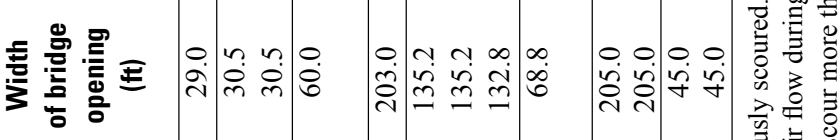
:

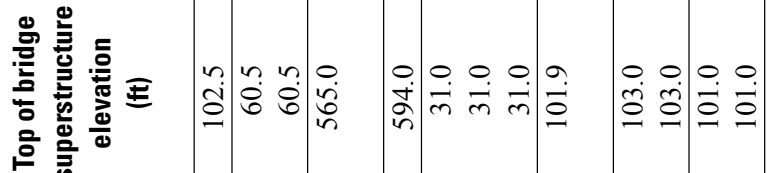

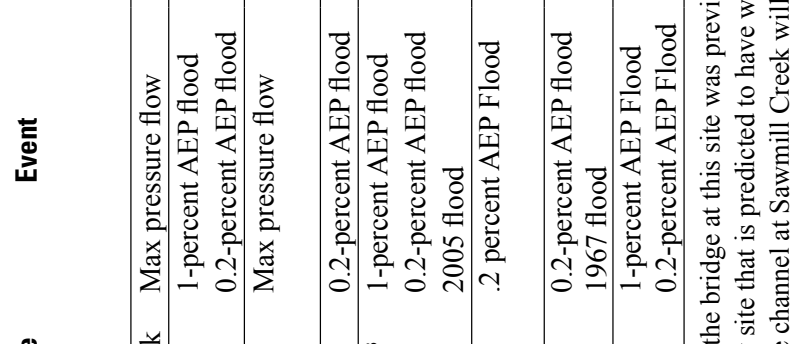

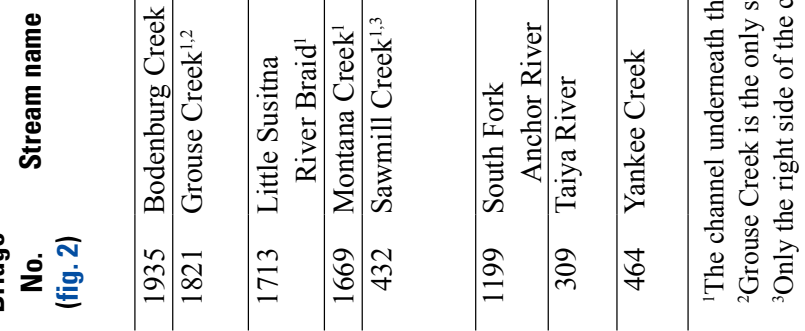




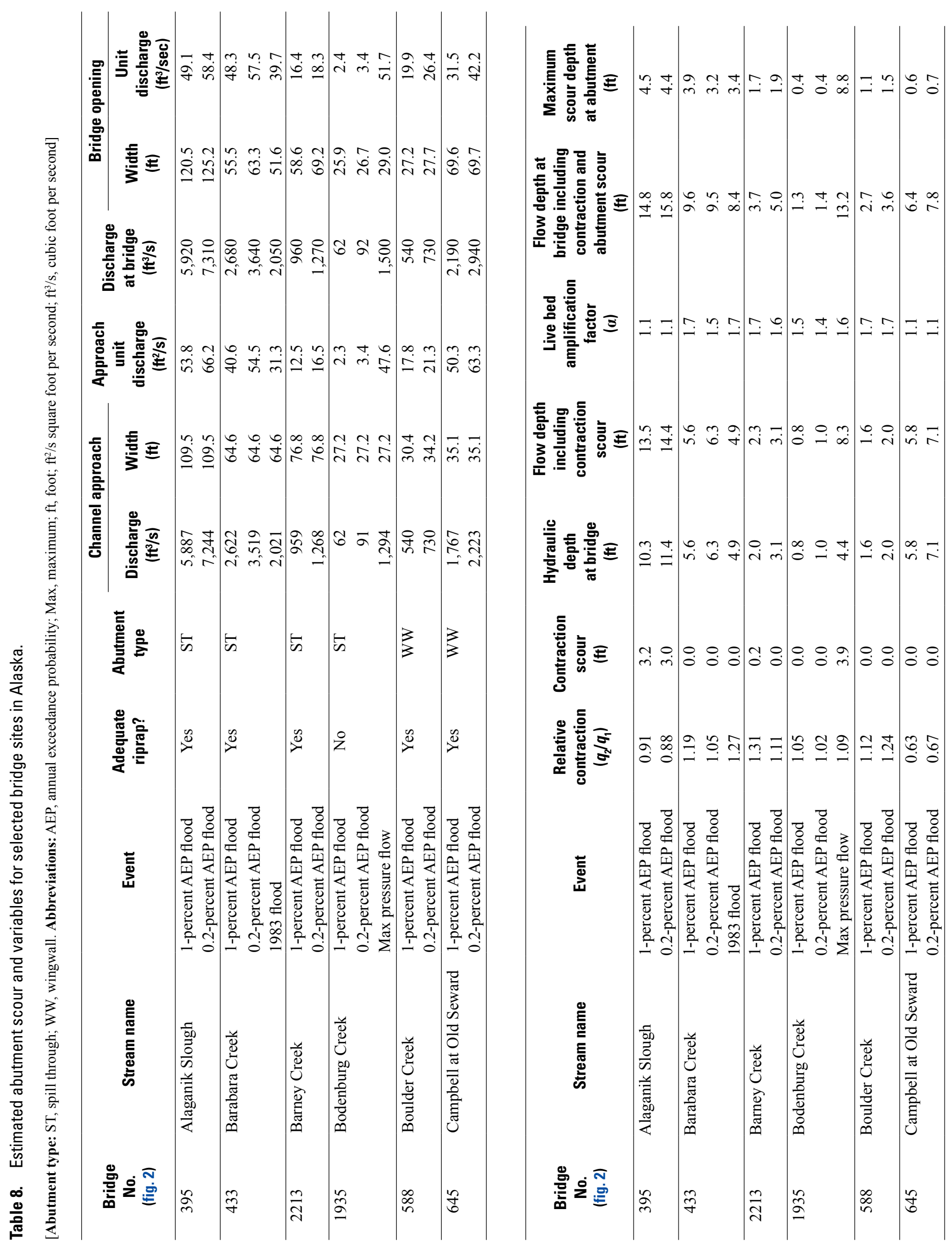




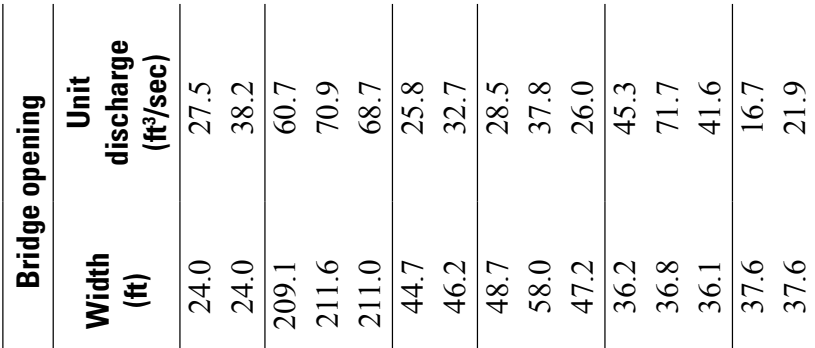

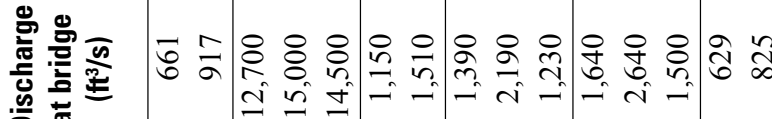

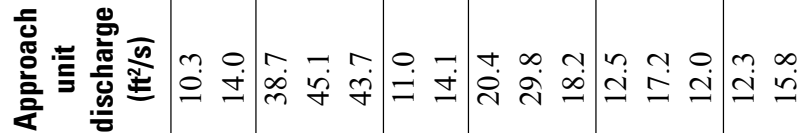

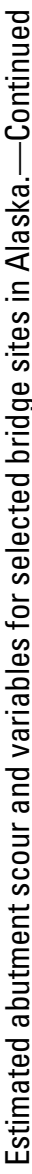

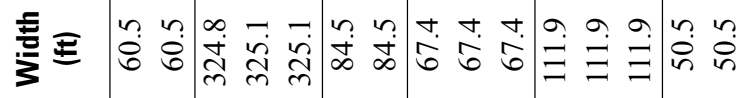

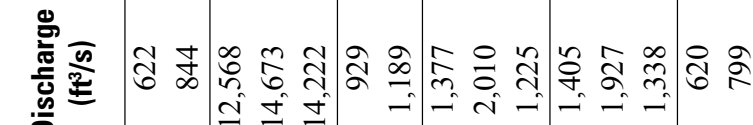

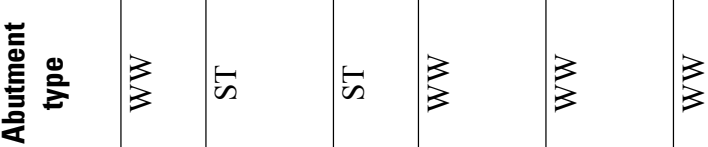

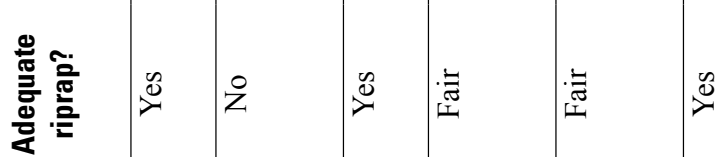

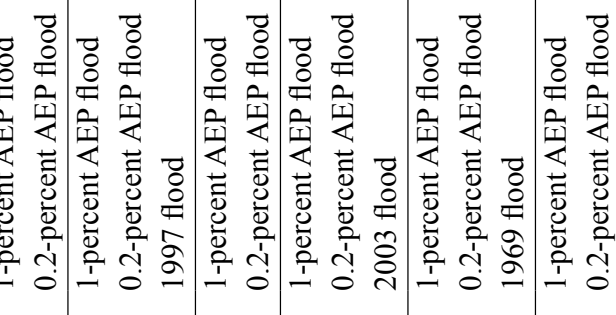

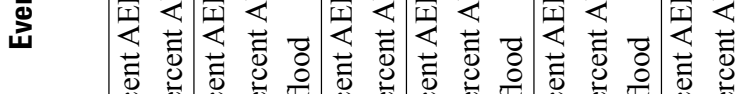

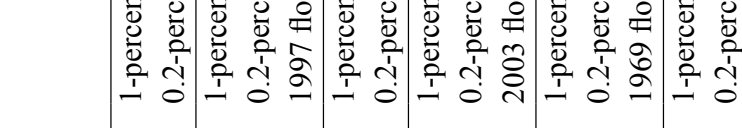
竞

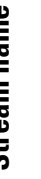
(2)

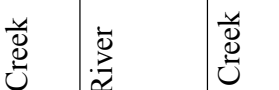

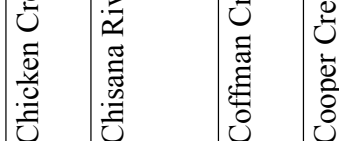

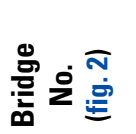

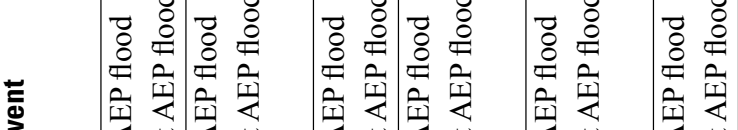

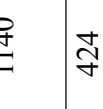

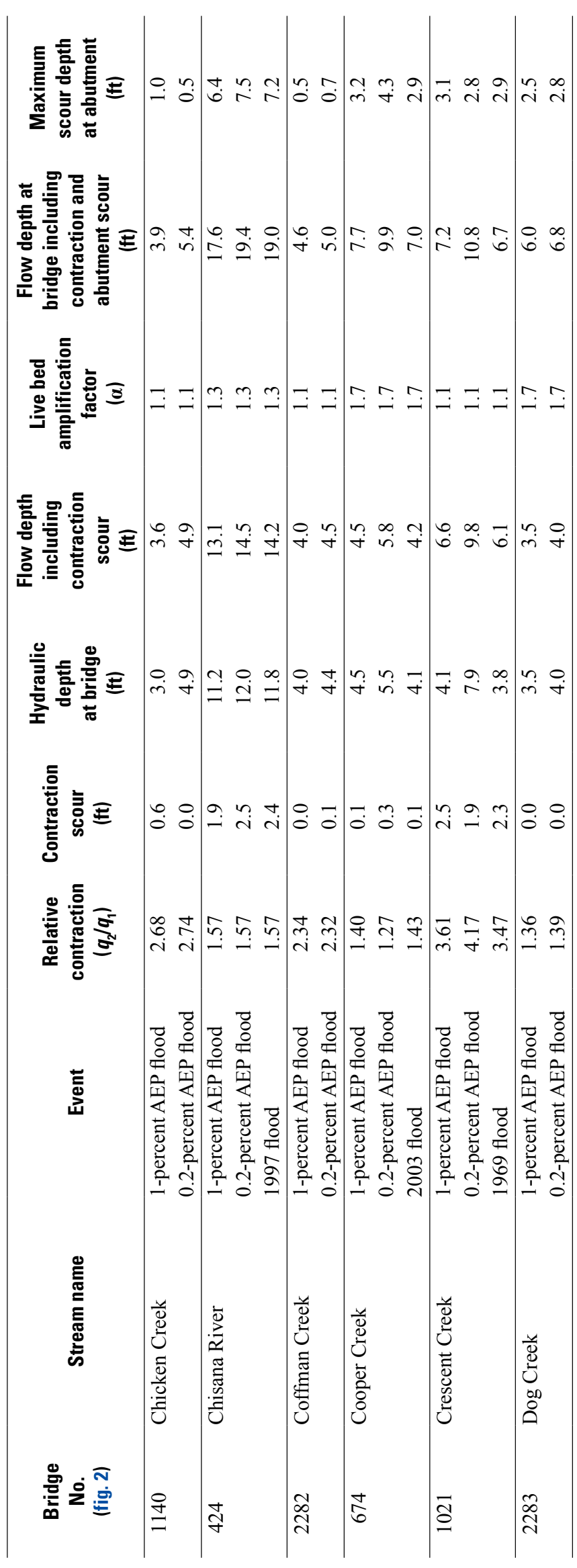




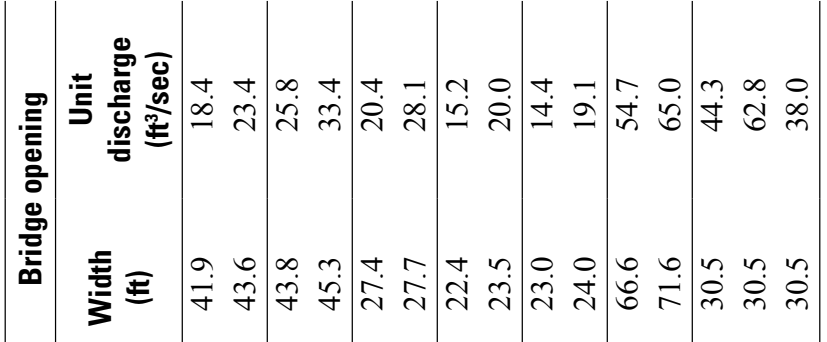

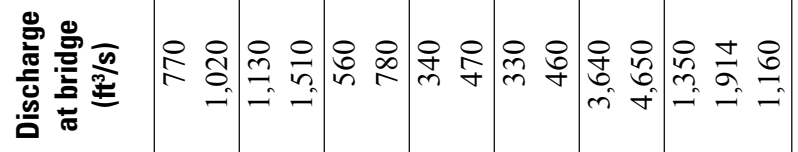

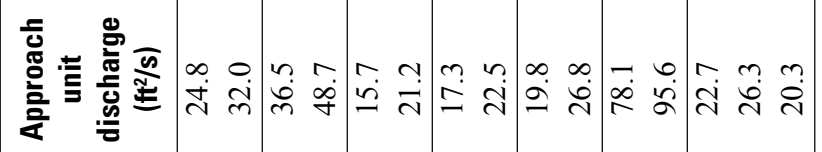

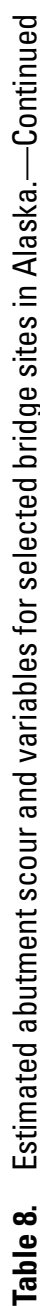

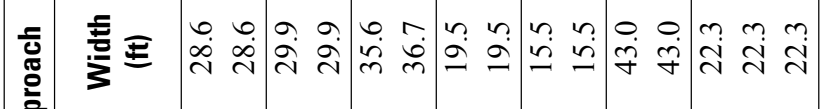

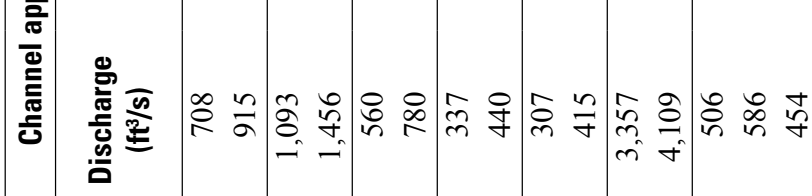

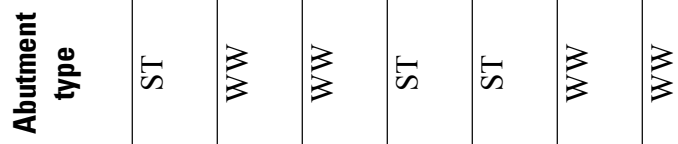

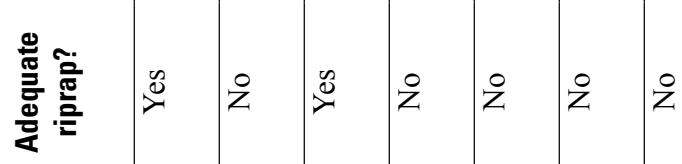

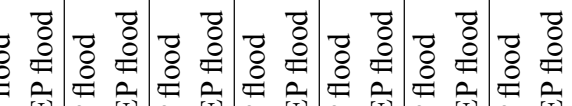

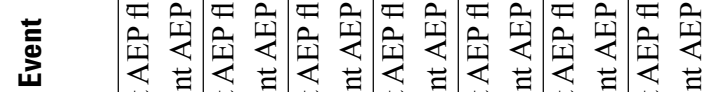

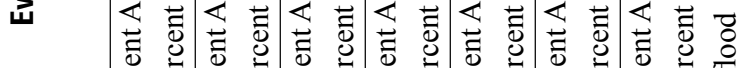

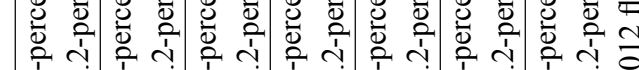

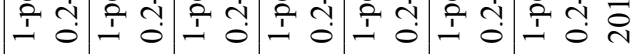

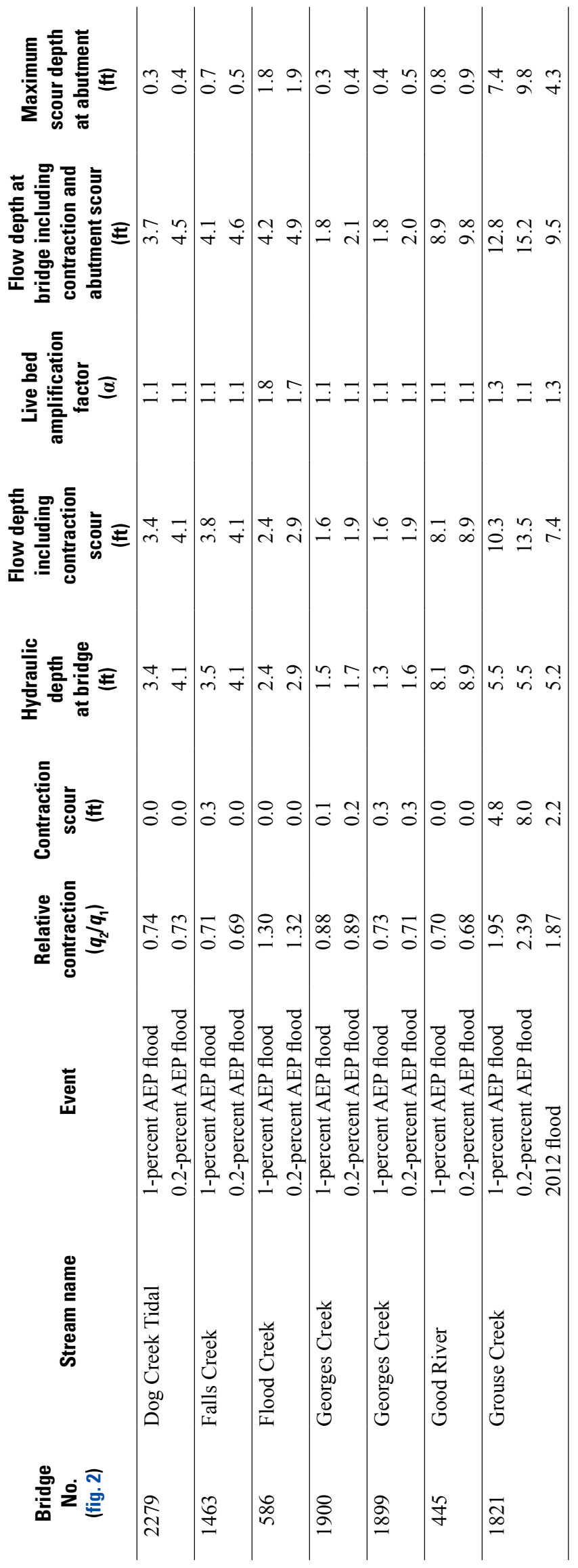




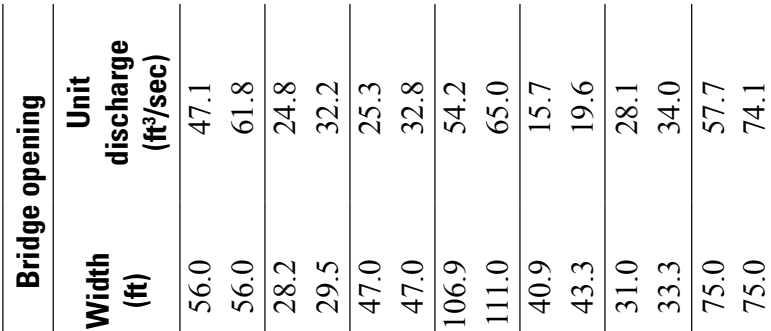

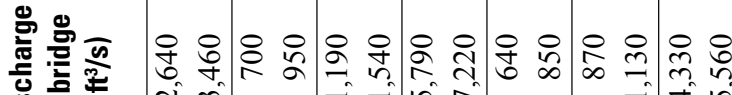

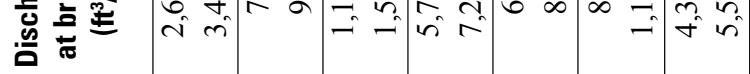

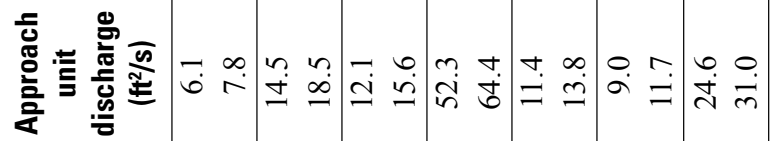

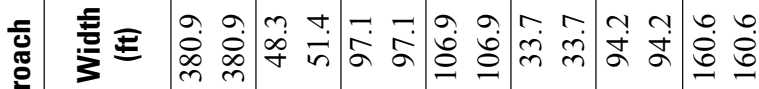

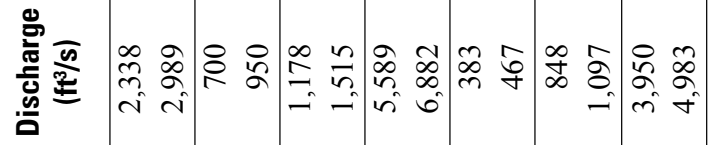

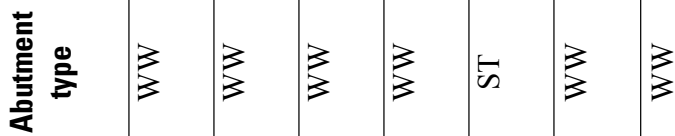

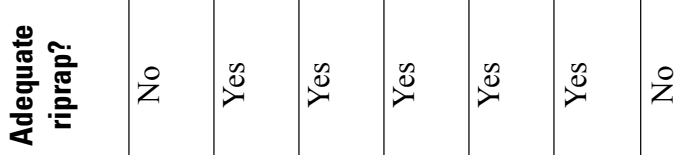

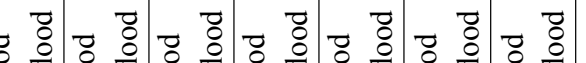

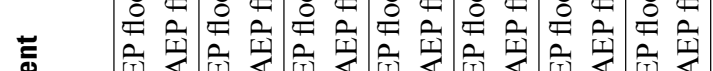

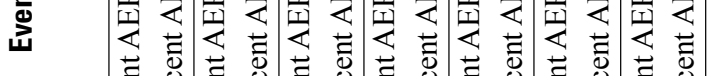

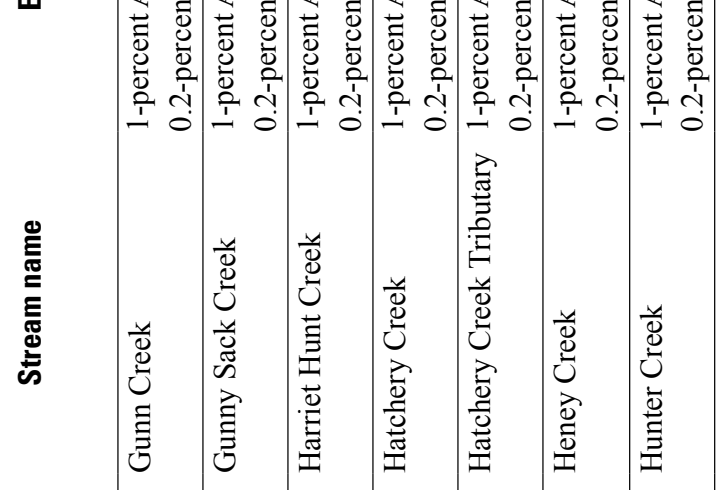
兽完离

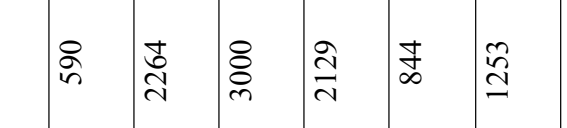

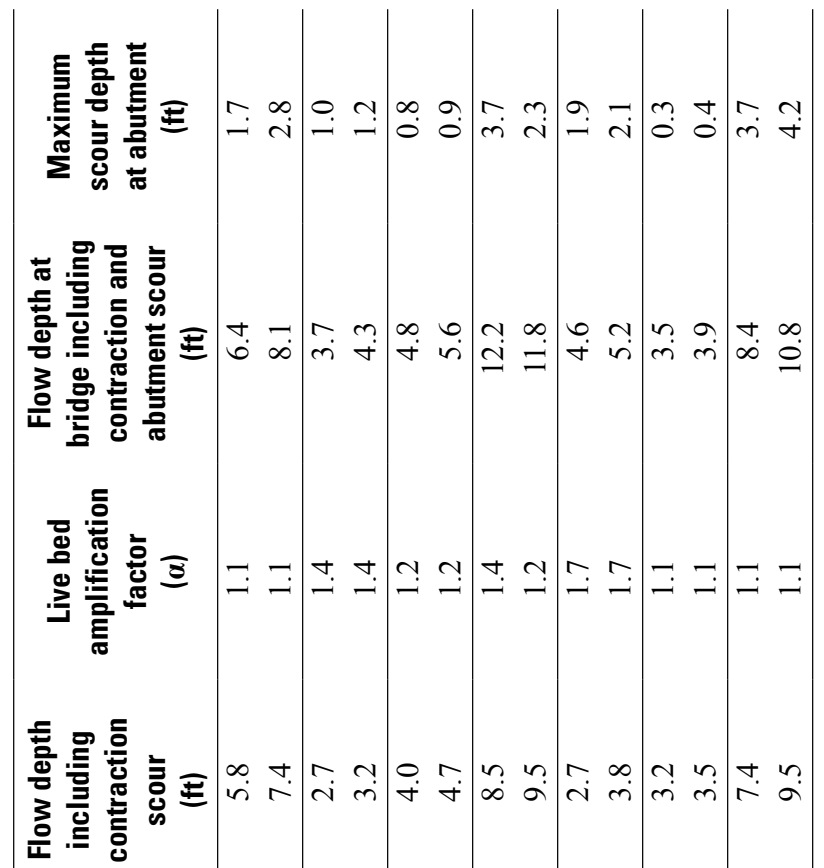

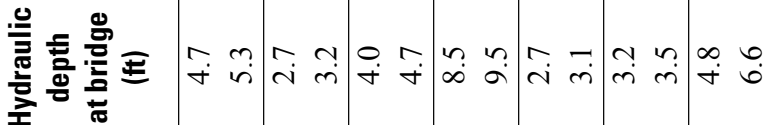

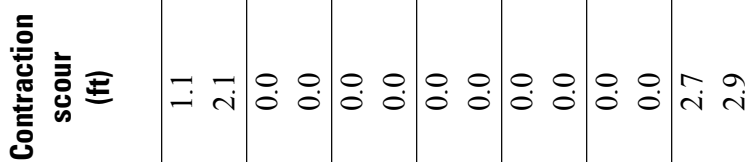

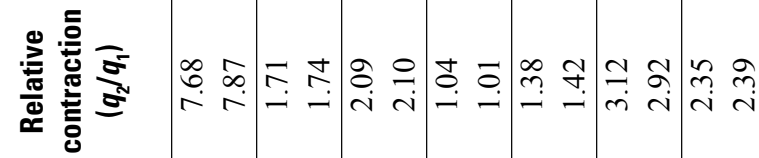

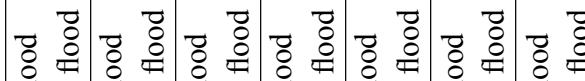

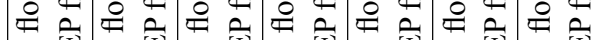

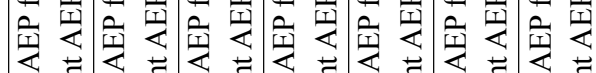

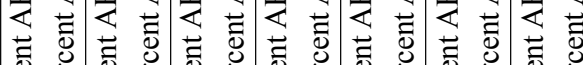

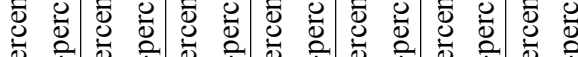

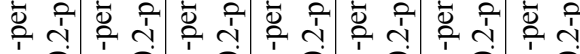

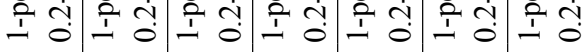

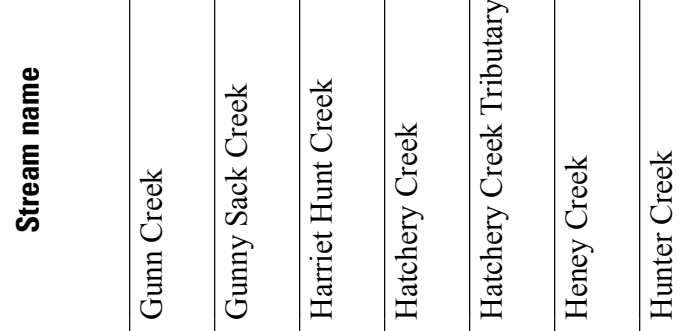

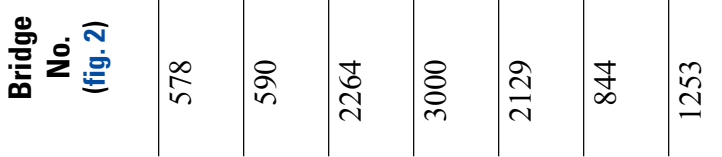




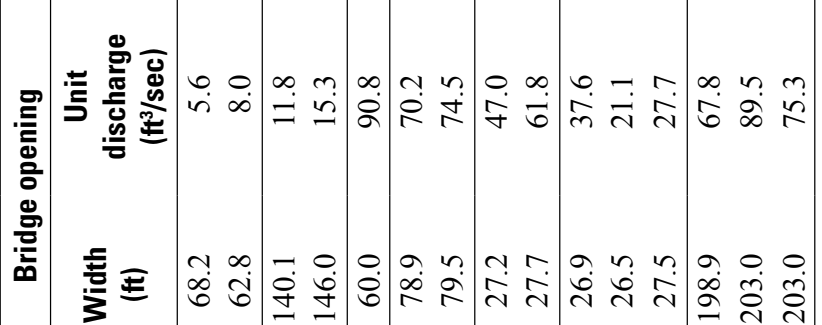

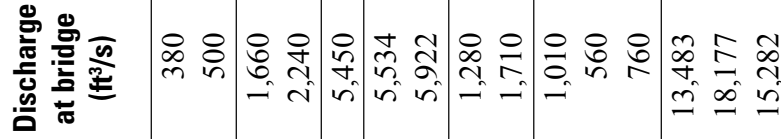

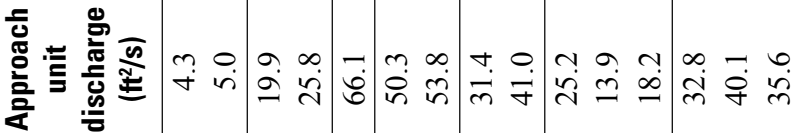

过

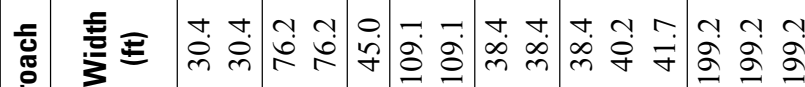
흔

产

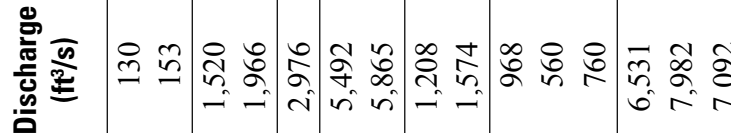

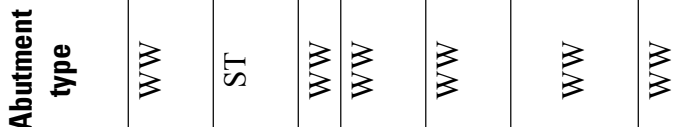

章恣

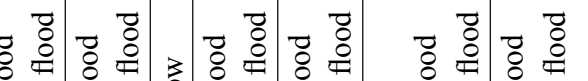

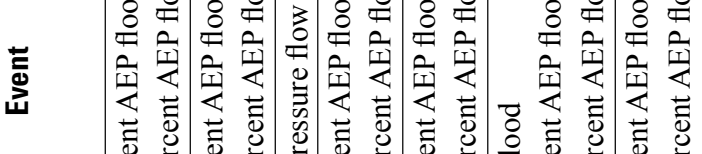

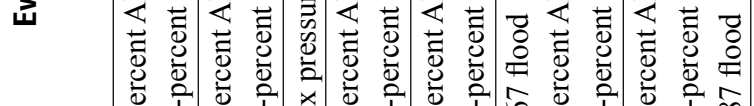

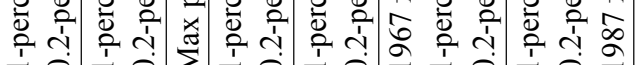

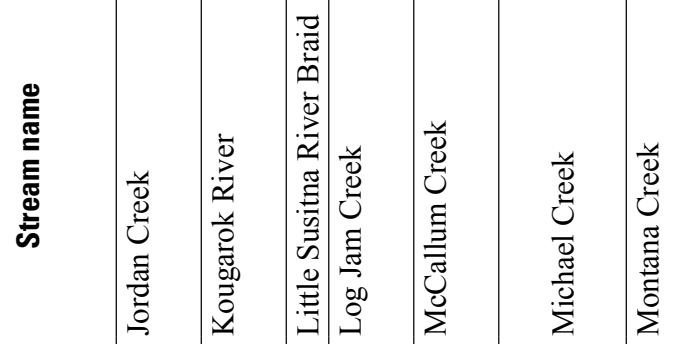

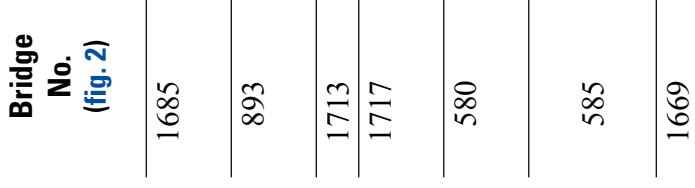

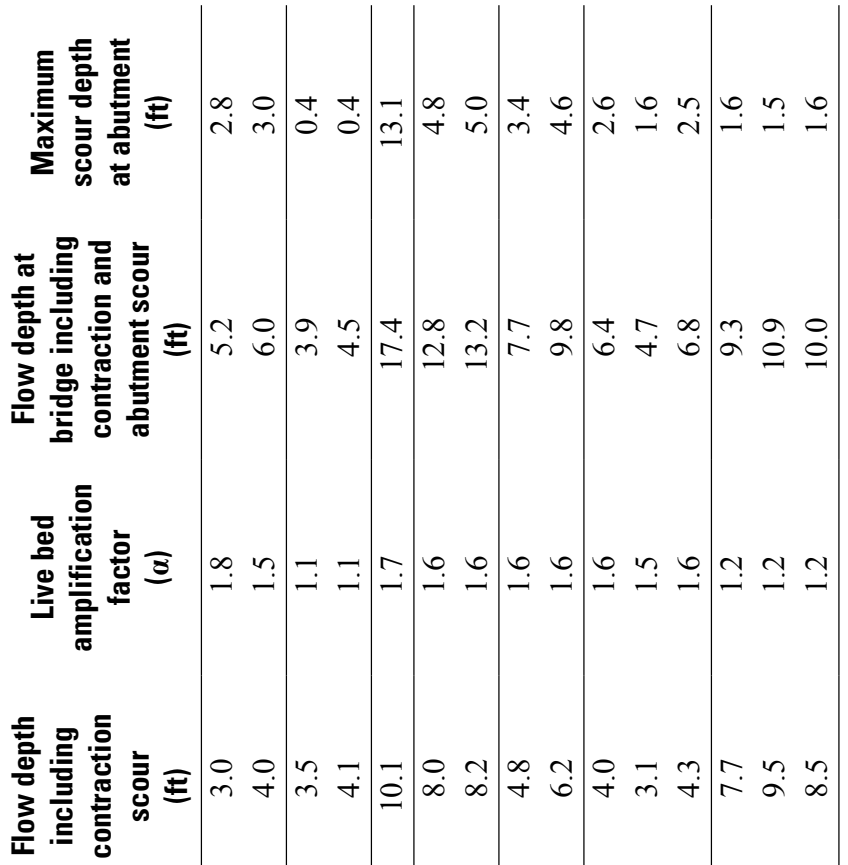

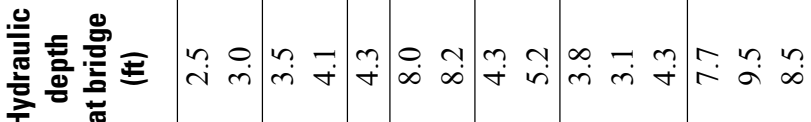

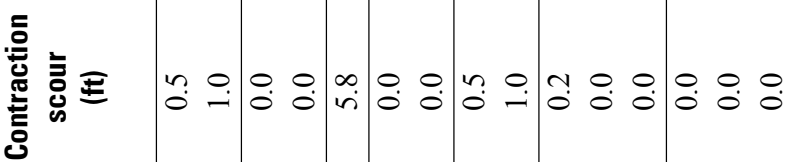

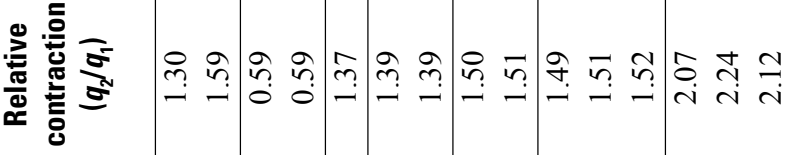

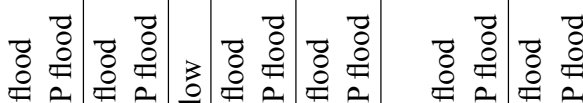

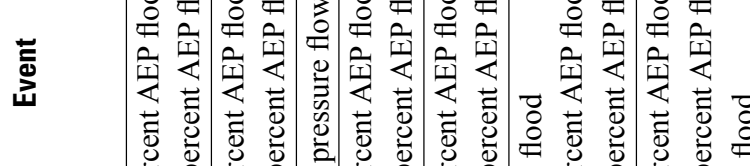
过

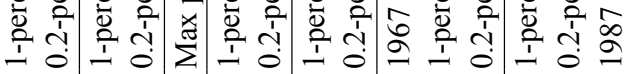

离

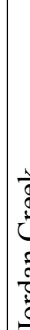

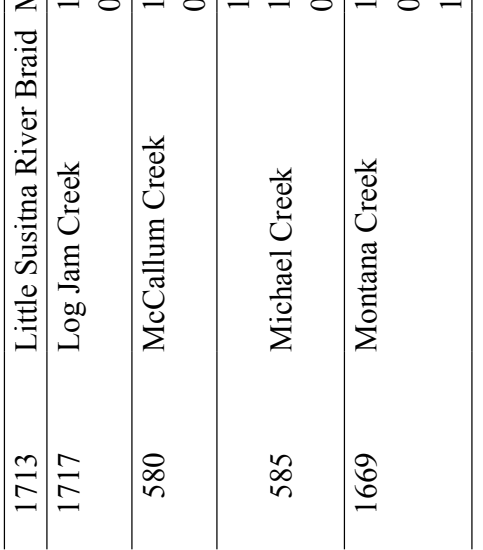




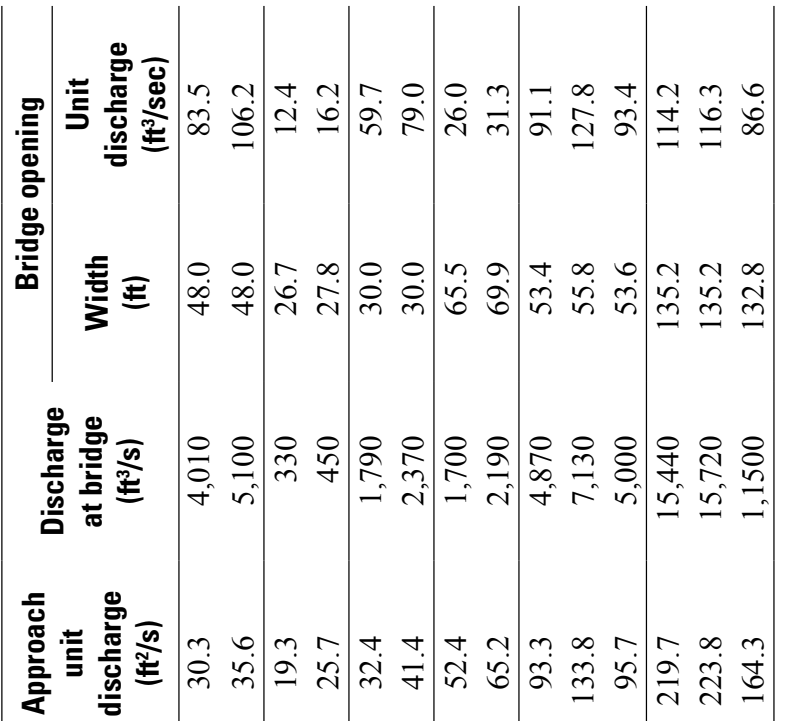

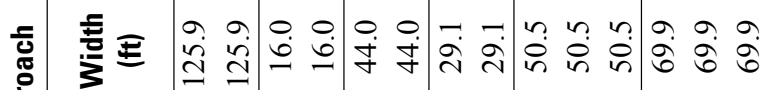

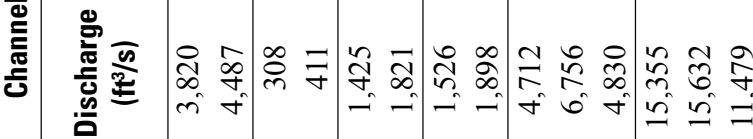

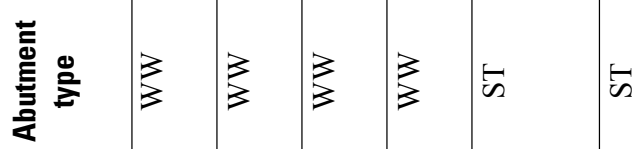

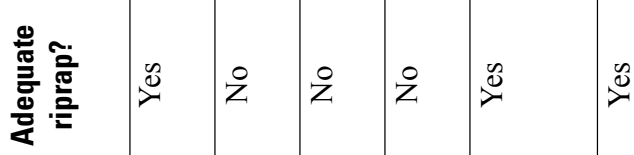
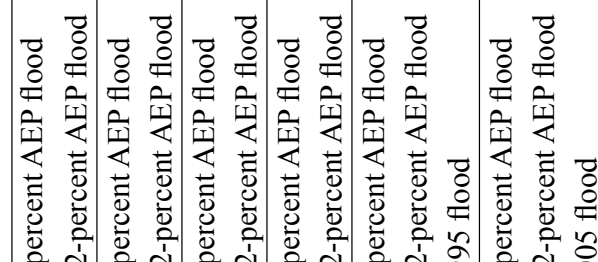

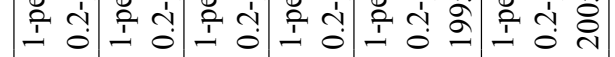

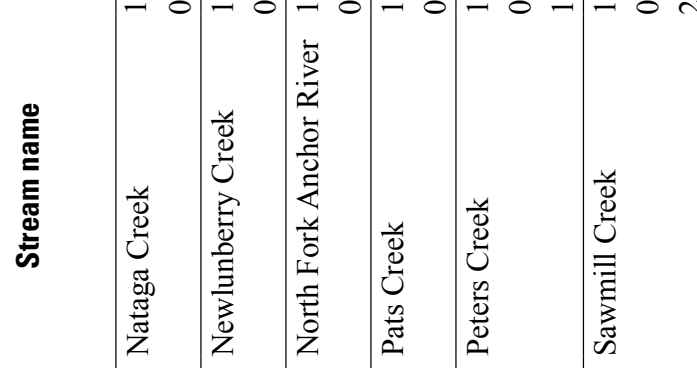

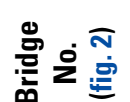

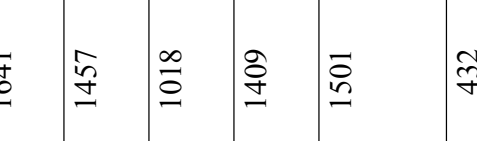

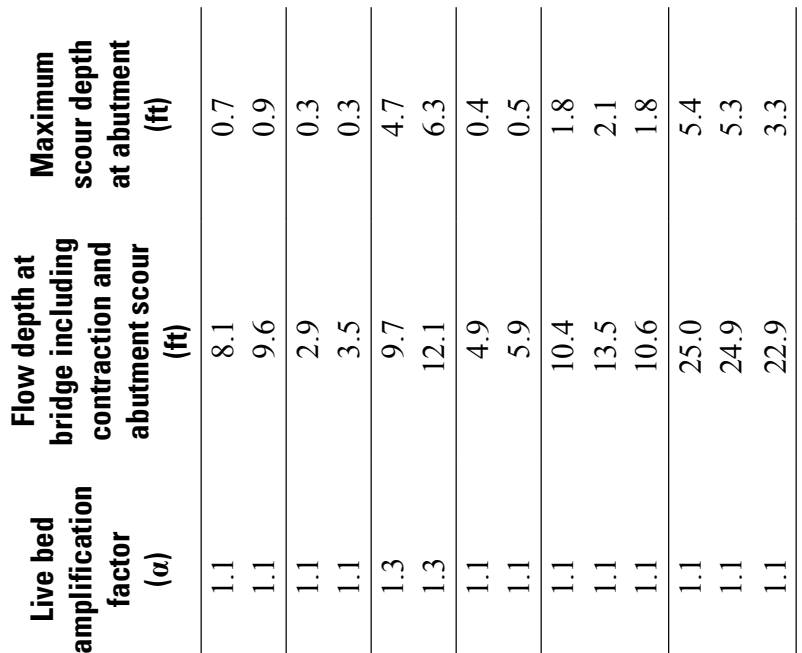

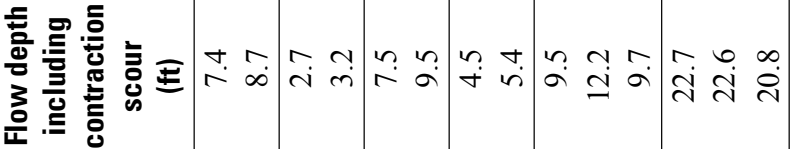

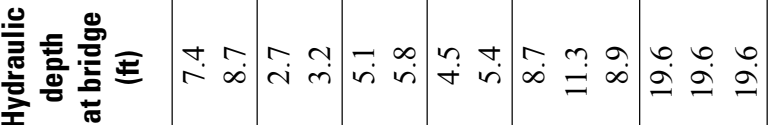

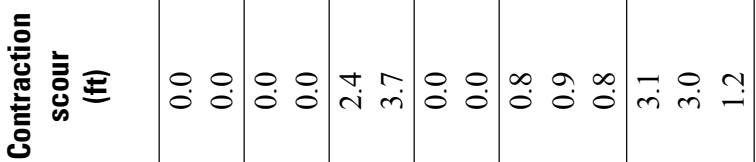

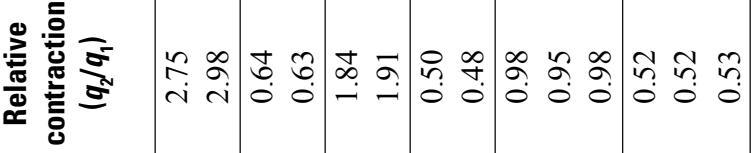

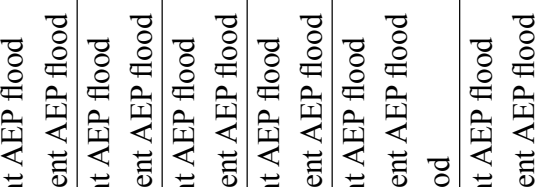

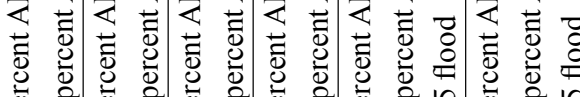

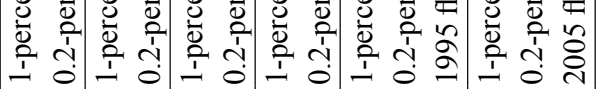

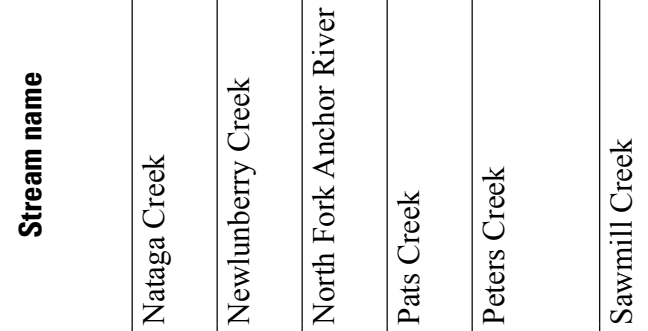

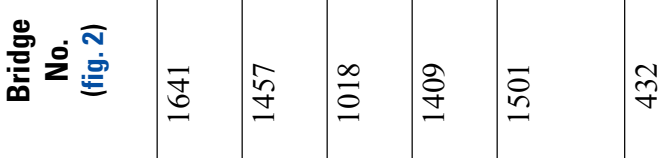




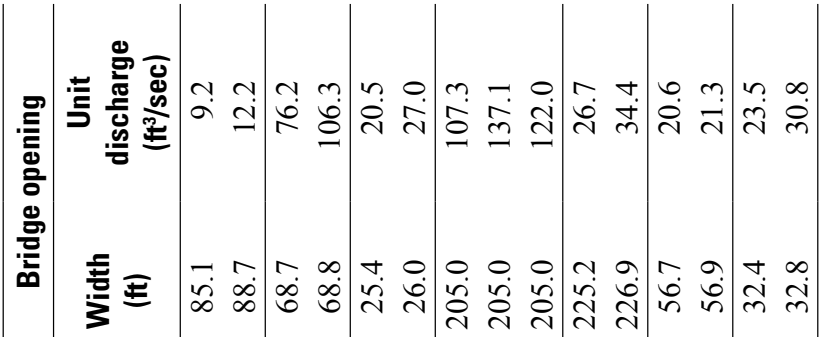

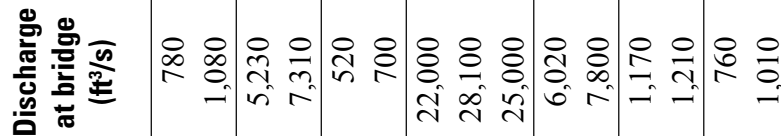

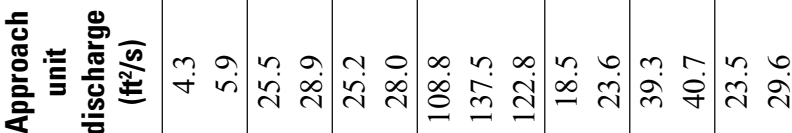

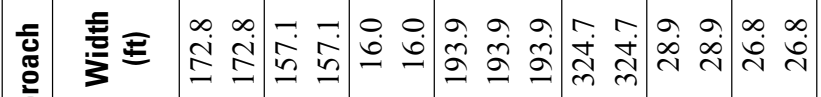

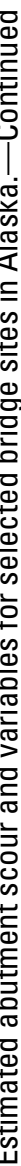

$\stackrel{\infty}{\frac{0}{\pi}}$

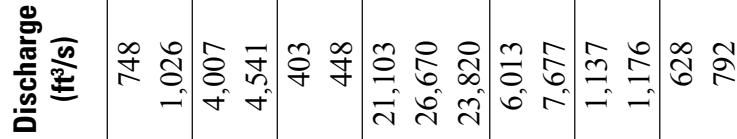

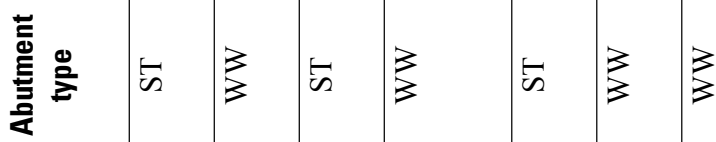

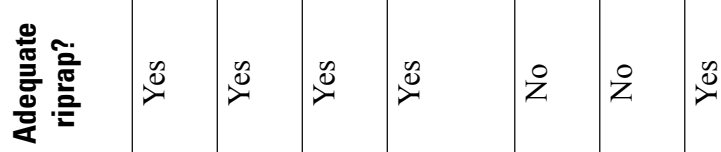

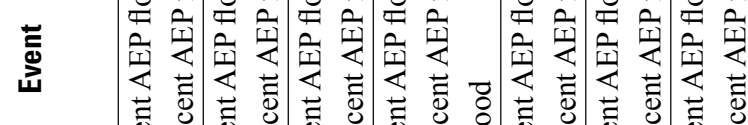
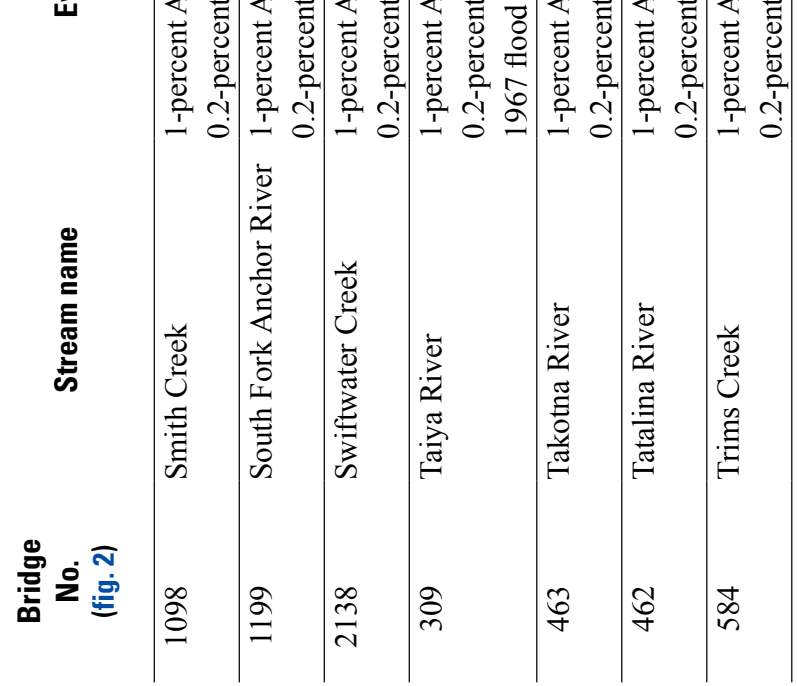

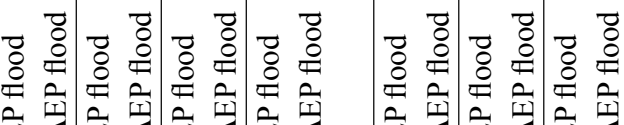

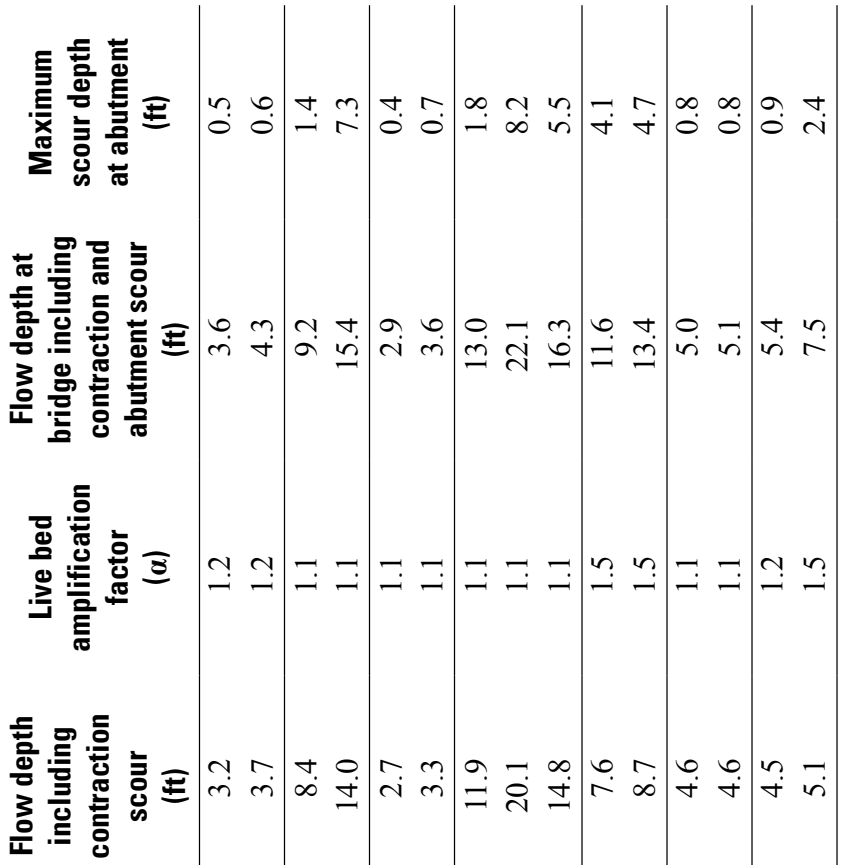

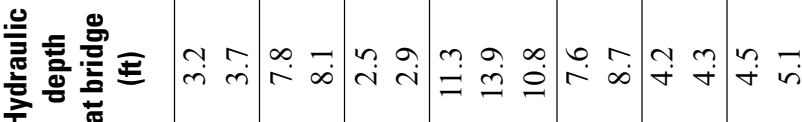

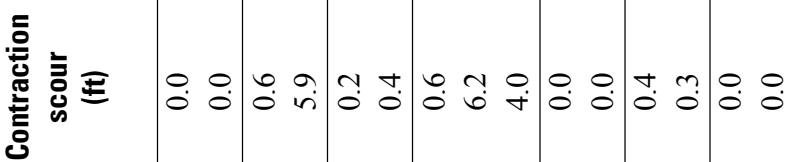

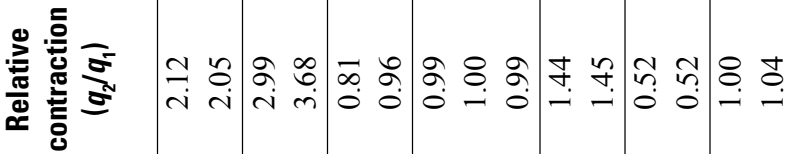

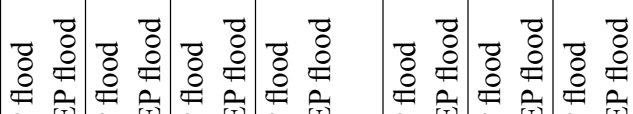

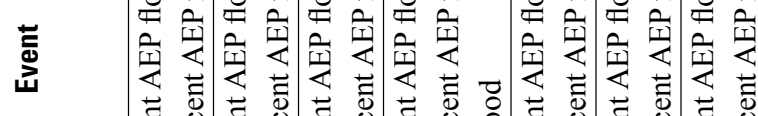

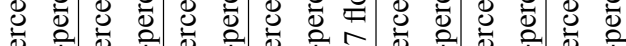

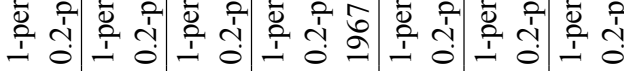

壱

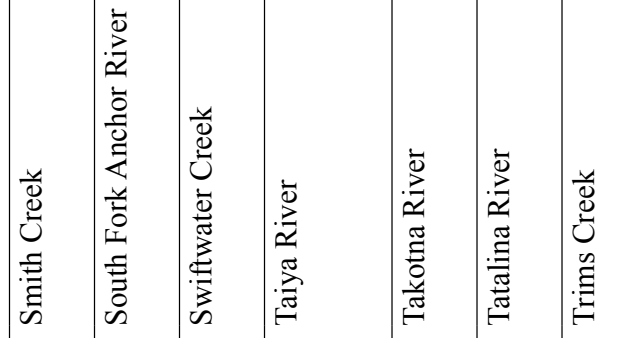

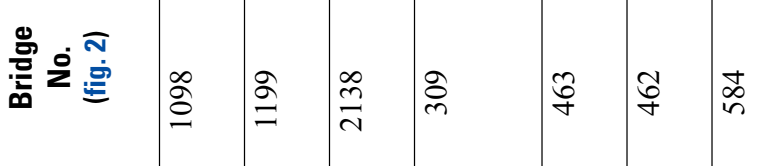




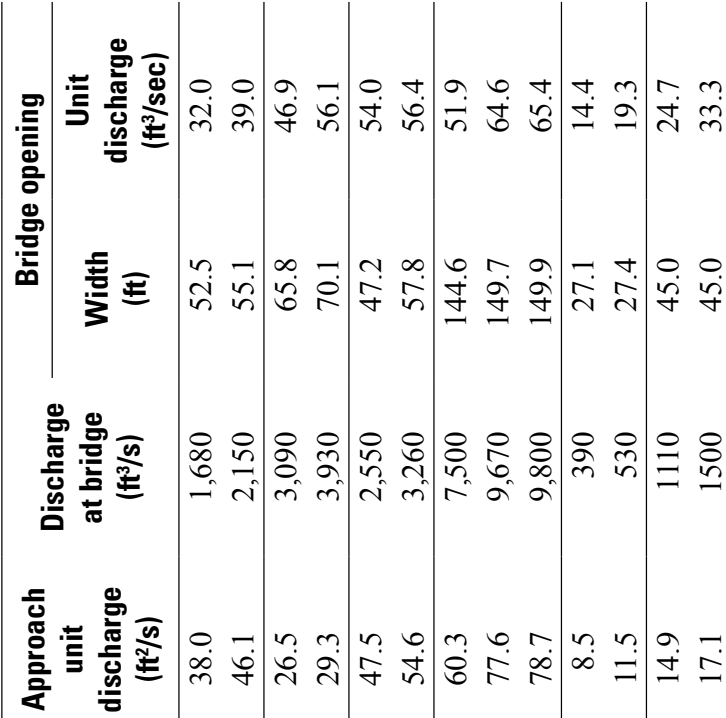

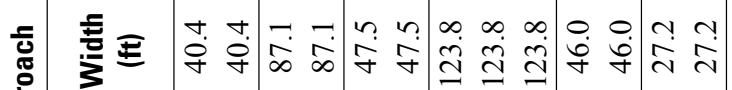

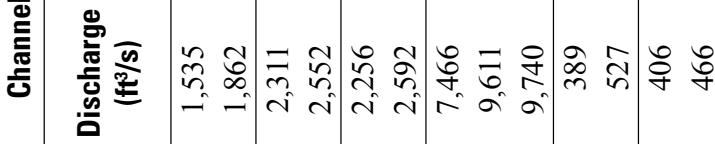

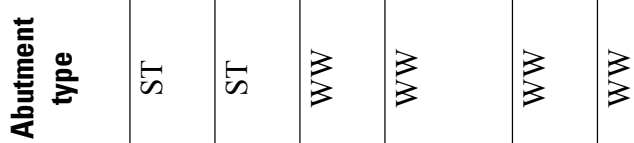

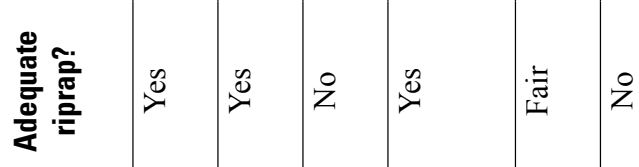

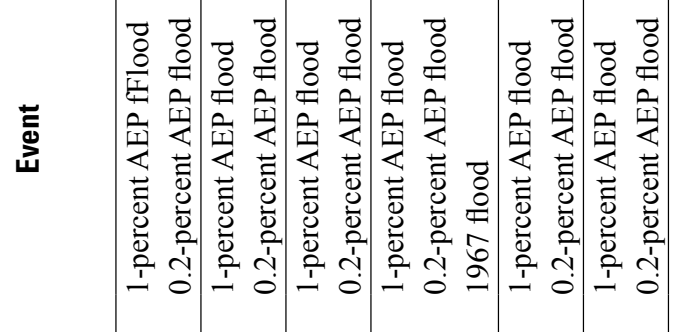

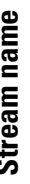

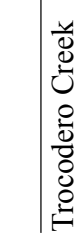

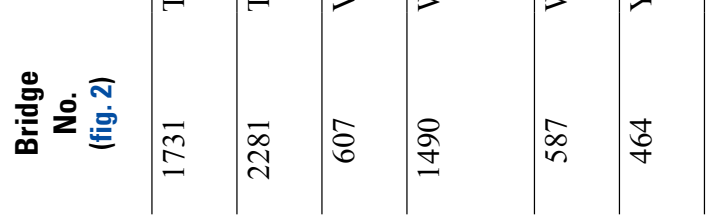

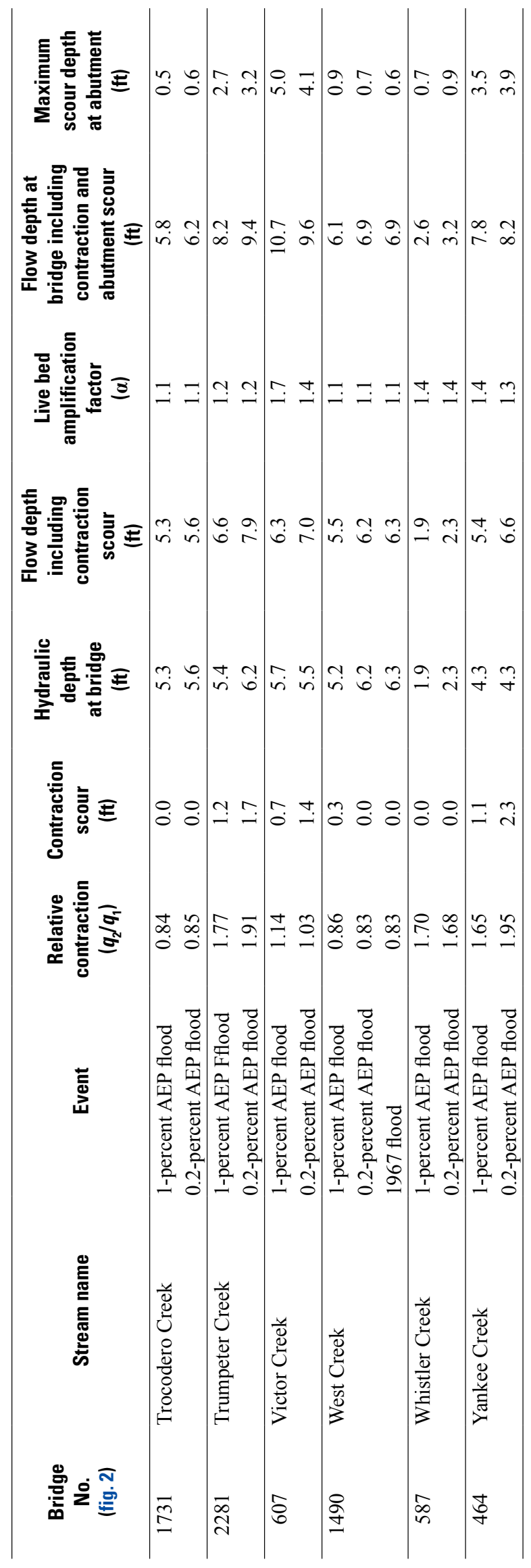




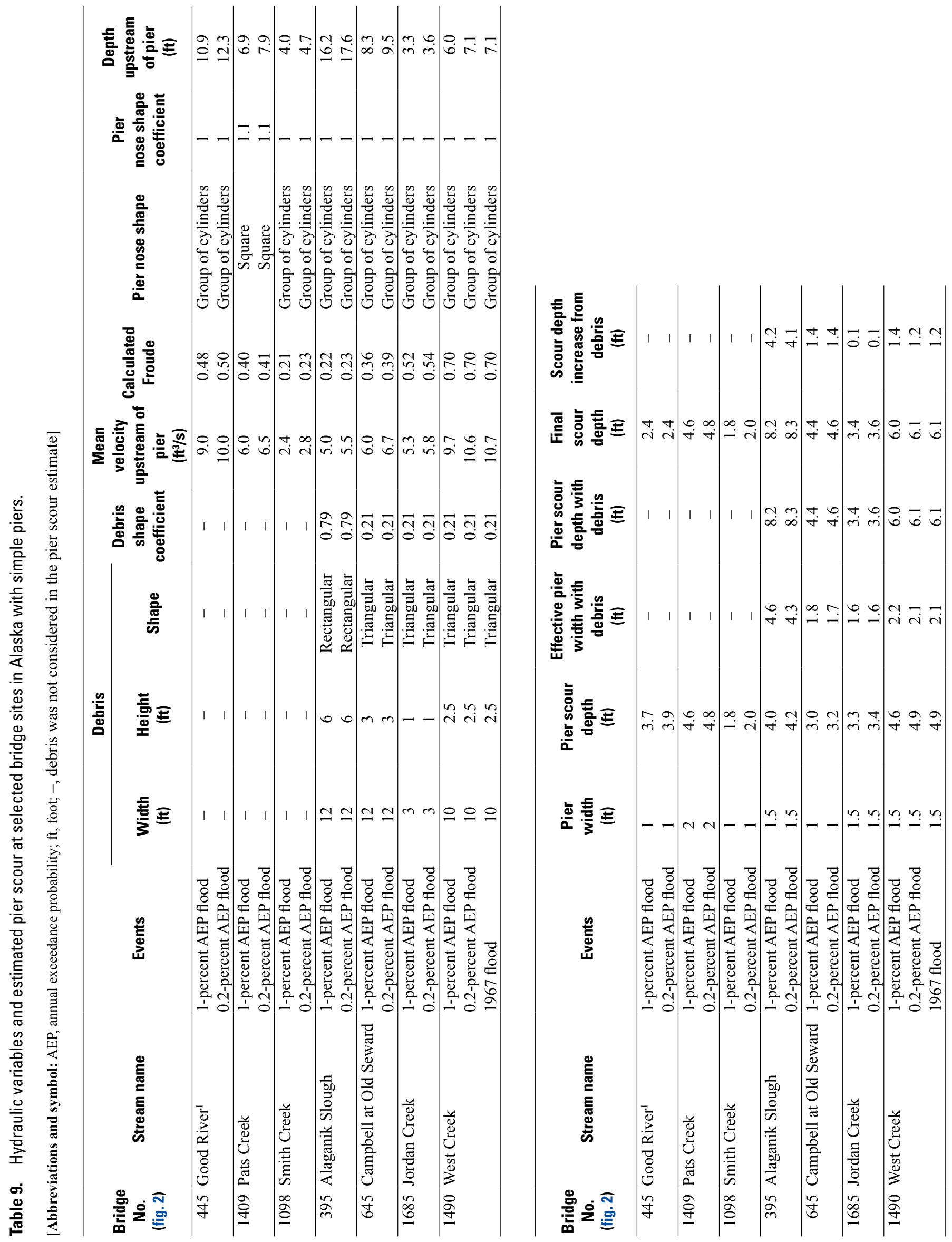



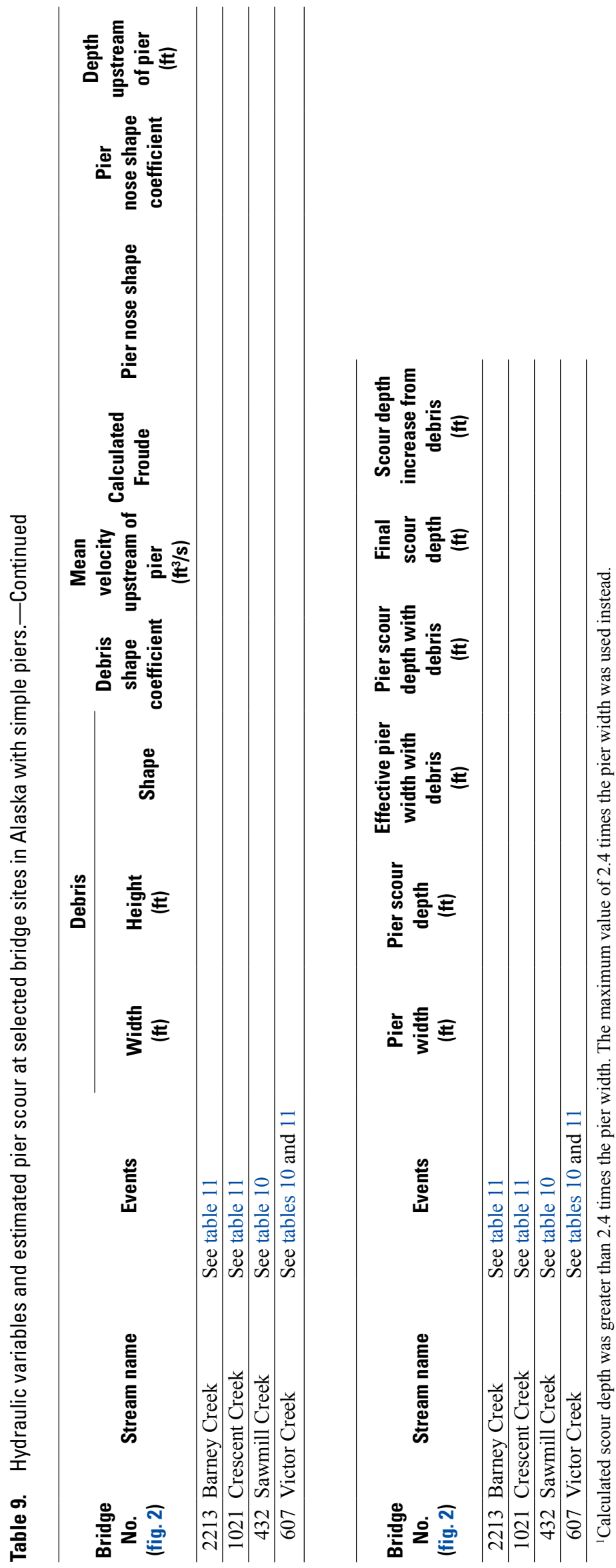


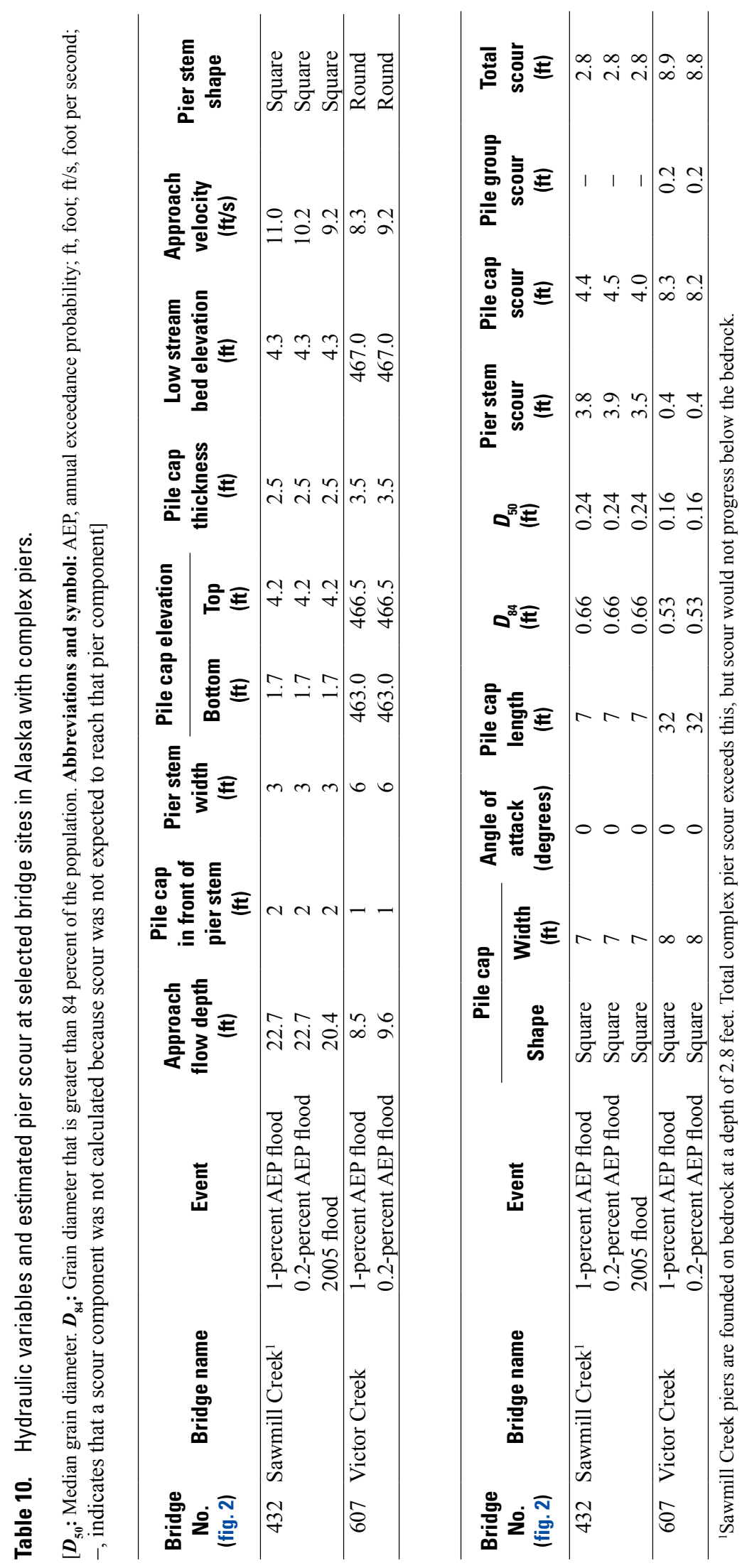




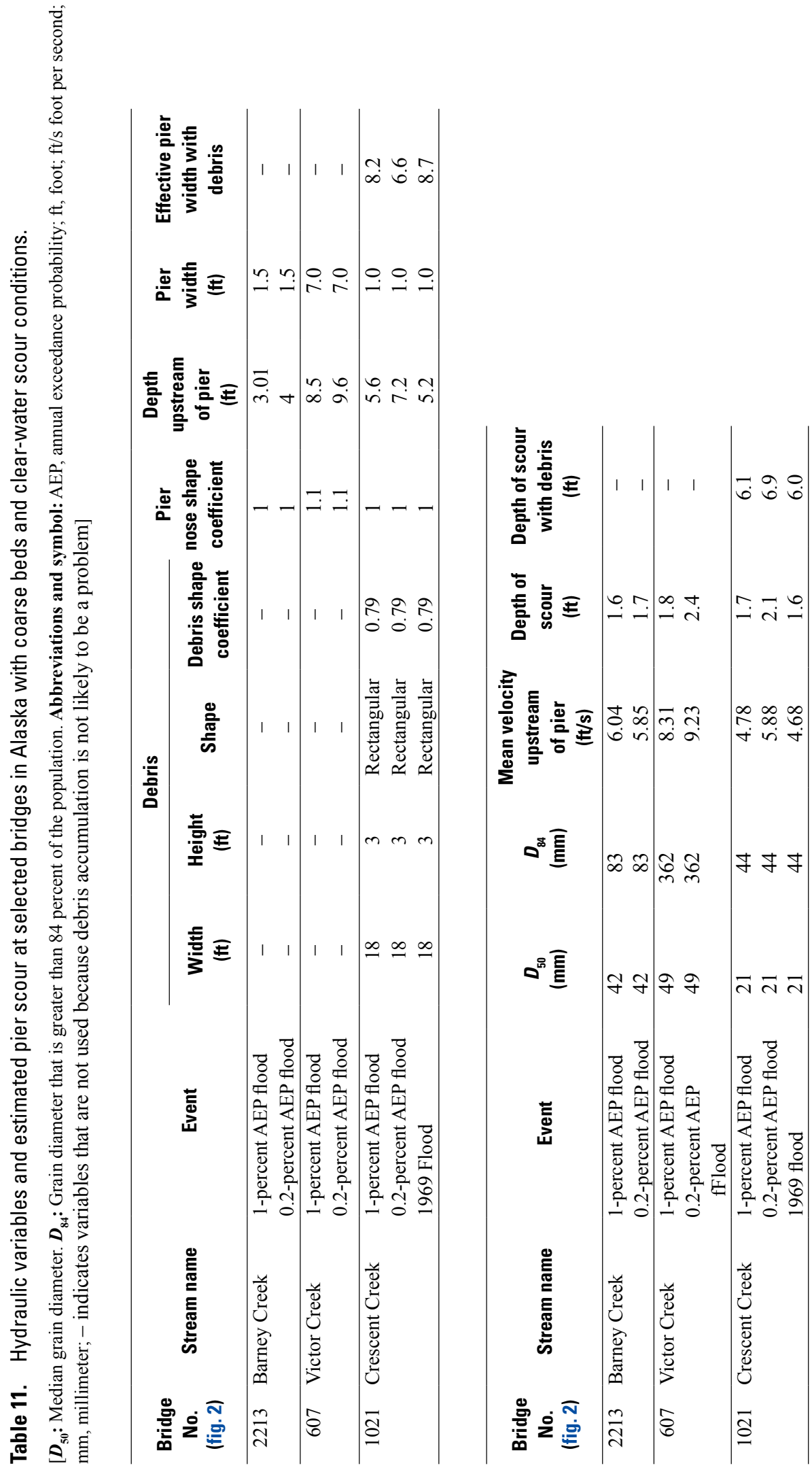




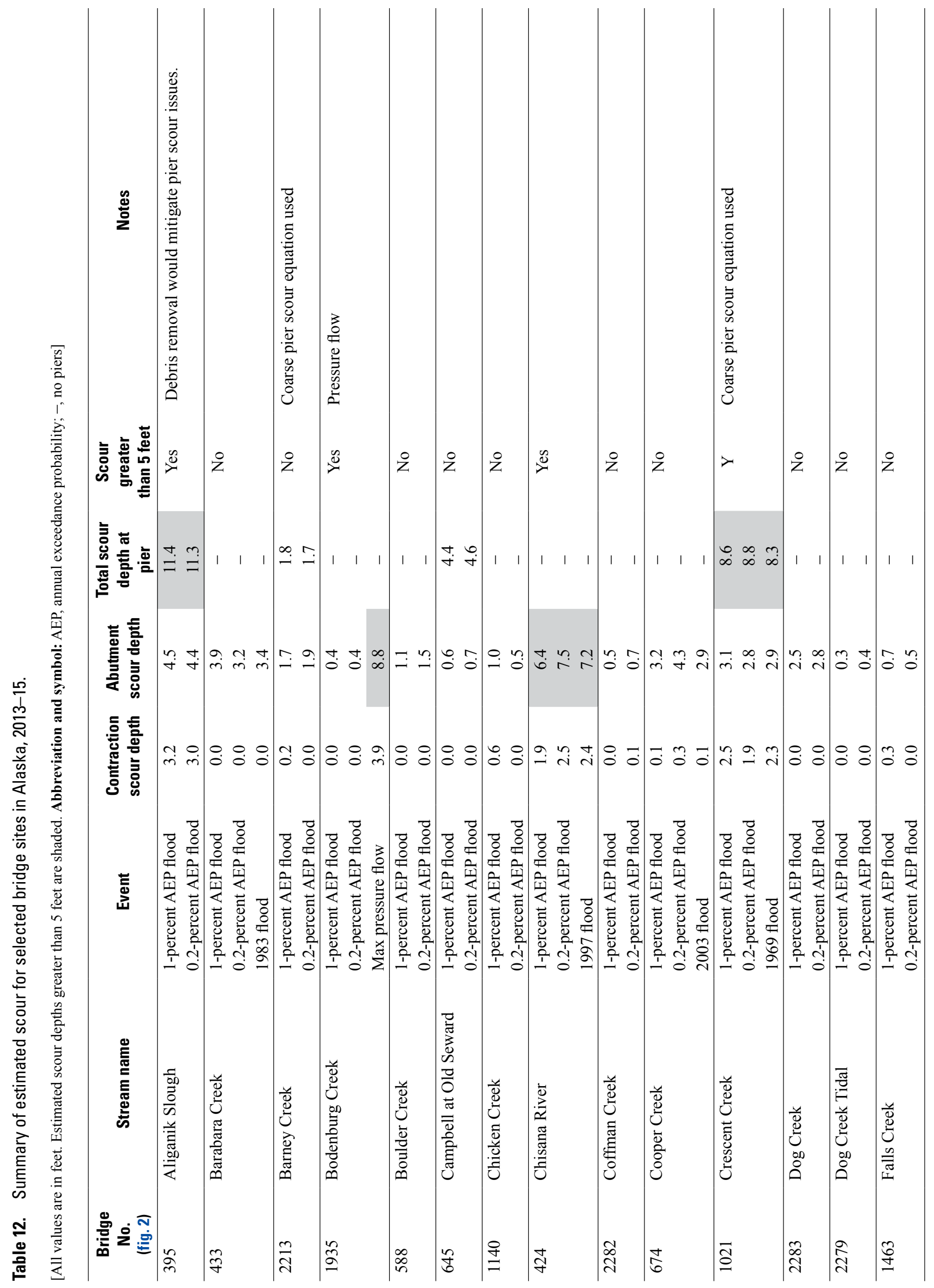




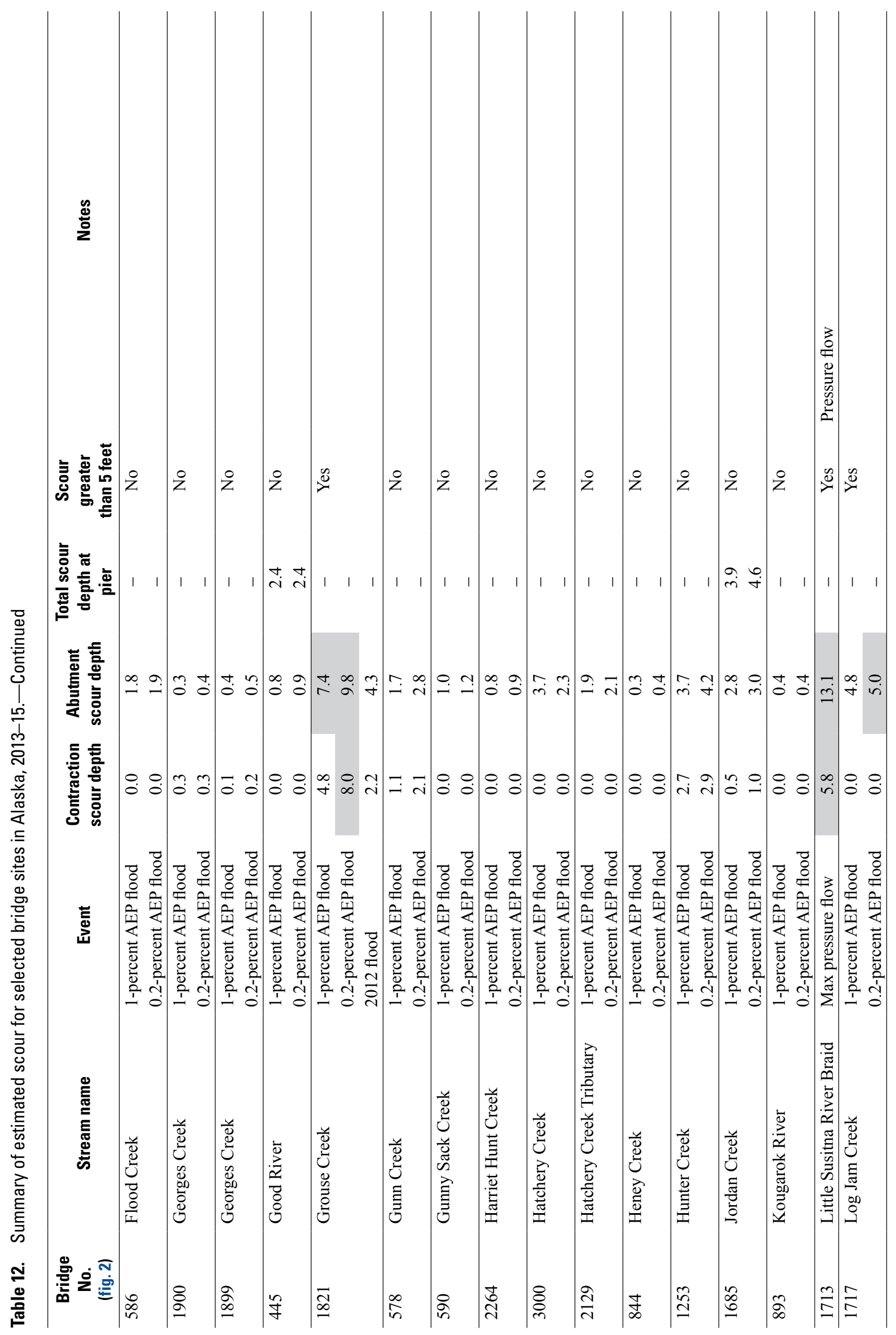









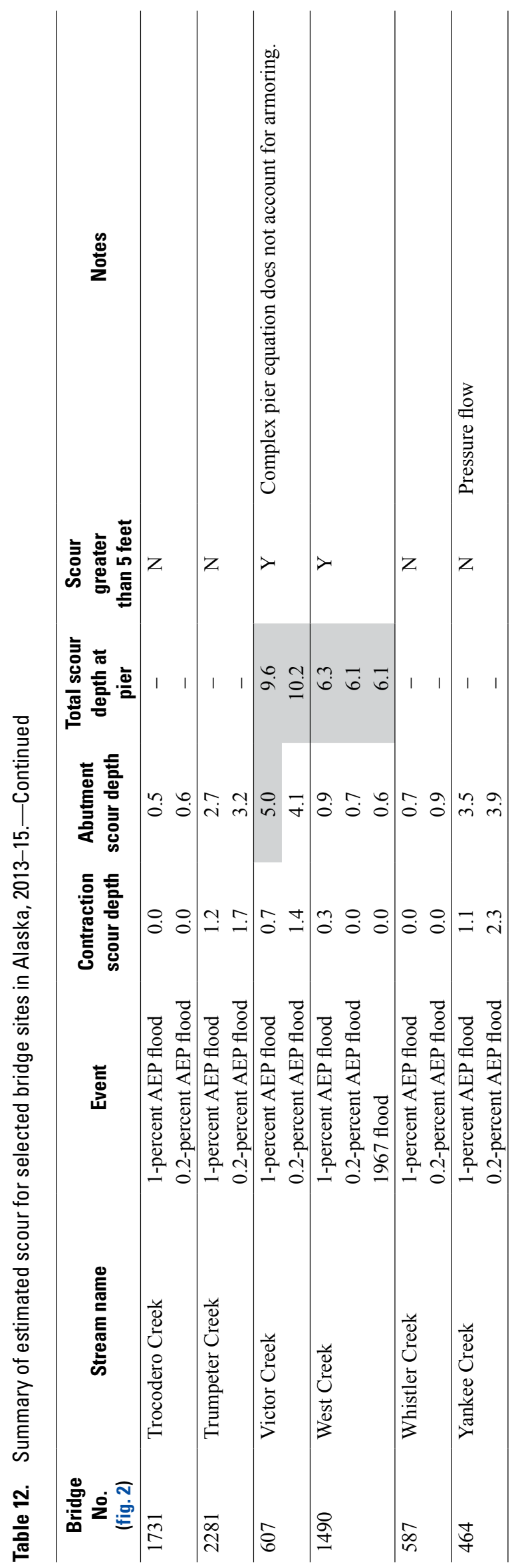




\section{Bridges with High Scour Estimates}

Five feet is considered the threshold for "substantial scour", although the influence of scour on the bridge structure ultimately depends on the depth of the bridge foundations. Those bridges coded as $\mathrm{U}$ in table 1 are founded on piles of unknown depth; thus, these numbers may be used to prioritize bridge for pile-depth testing. Only 9 of the 52 sites have substantial scour estimates at the design flood or largest measured flood, and four additional sites have substantial scour estimates for the check flood. These and other bridges of concern are described individually.

\section{Alaganik Slough Bridge 395}

Pier scour of $11.3-11.4 \mathrm{ft}$ is the primary concern at Alaganik Slough Bridge 395. A 2002 underwater inspection noted scour holes $1.5-4 \mathrm{ft}$ deep around the pilings, and scour near the left abutment. Debris accumulations, noted in every inspection report, increase estimated pier scour by more than $4 \mathrm{ft}$. Photographs show debris on the upstream pile and wedged between piles, as well as on the streambed near the bridge. The sounding record shows a change in low streambed elevation of $3.5 \mathrm{ft}$ between 1998 and 2008, indicating that the streambed is readily scoured.

\section{Bodenburg Creek Bridge 1935}

The check flood for Bodenburg Creek is based on overflow from the Matanuska River filling the channel to capacity at Bridge 1935 . This flow of $1,500 \mathrm{ft}^{3} / \mathrm{s}$ would scour the channel an estimated $3.9 \mathrm{ft}$, with $8.8 \mathrm{ft}$ of scour at the abutments. The 1-and 0.2-percent AEP floods derived from the surface drainage basin of Bodenburg Creek are estimated to cause very minor scour.

\section{Chisana River Bridge 424}

Chisana River at Bridge 424 is a low-gradient meandering river with a mobile sand and fine gravel bed. The 252 -ft bridge easily accommodates the estimated 1 - and 0.2 -percent AEP floods, and had a $14,500 \mathrm{ft}^{3} / \mathrm{s}$ flood in 1997 (similar to the 0.2-percent AEP flood of $15,000 \mathrm{ft}^{3} / \mathrm{s}$ ). Soundings show a change in low bed elevation of $3.1 \mathrm{ft}$. Estimated abutment scour of 6.4-7.5 ft during floods does not seem excessive for this large of a channel; however, the modeled water surface does not extend all the way across the bridge opening, so only one abutment is likely to be scoured in a given flood.

\section{Crescent Creek Bridge 1021}

Crescent Creek has an estimated pier scour of 6.0-6.9 ft, with an accumulation of debris and accounting for channel armoring with the coarse bed equation. With contraction scour, this increases to $8.3-8.6 \mathrm{ft}$. This seems excessive for a small stream with no evidence of pier or contraction scour in soundings or post-flood reports. The bridge survived a flood in 1969 that was greater than the 1-percent AEP flood, with a predicted scour of $8.3 \mathrm{ft}$ at piers. One-dimensional modeling may not adequately capture the flow distribution at Crescent Creek, which is perched on an inactive alluvial fan with one side of the floodplain sloping away from the channel for several miles. The fluvial geomorphology of this reach suggests some flood flow would be expected to escape the channel and cross the approach road. Crescent Creek Bridge 1021 may be a good candidate for pile-depth testing, more frequent monitoring, or two-dimensional modeling.

\section{Grouse Creek Bridge 1821}

Grouse Creek Bridge 1821 is a small bridge with vertical sheet pile cell abutments spanning a mobile-bedded stream. Bridge 1821 is undersized, and has vertical contraction at the 1 - and 0.2-percent AEP flows, and weir flow at the 0.2-percent AEP flow. Contraction scour of $4.8 \mathrm{ft}$ and abutment scour of $7.4 \mathrm{ft}$ are estimated for the 1-percent AEP flood. Even at low flow, the water surface is against both abutments, and inspection reports note that the abutments are not protected by riprap.

\section{Little Susitna River Braid Bridge 1713}

Bridge 1713, built in 2011, spans a sub-channel of the Little Susitna River in a braided reach. An indefinite proportion of the estimated 1- and 0.2-percent AEP floods would enter this channel, so a "maximum pressure flow" was determined that would fill the channel to capacity without losing substantial flow to the road approach. This flow is $5,450 \mathrm{ft}^{3} / \mathrm{s}$, compared to $7,740 \mathrm{ft}^{3} / \mathrm{s}$ measured in 2012 at an upstream streamgage, with estimates of 7,290 and 10,300 $\mathrm{ft}^{3} / \mathrm{s}$ for the 1- and 0.2-percent AEP floods, respectively. Estimated vertical contraction and abutment scour for a $5,450 \mathrm{ft}^{3} / \mathrm{s}$ flow are 5.8 and $13.1 \mathrm{ft}$, respectively. Low water measurements in 2013 showed that the streambed below the bridge was about $3.5 \mathrm{ft}$ lower than the uncontracted channel upstream and downstream, indicating that significant scour had already occurred. Because the bridge is new and $20 \mathrm{ft}$ longer than the original bridge, the sounding record is too short to derive any conclusions about stability. 


\section{Logjam Creek Bridge 1717}

Estimated abutment scour is high at Logjam Creek (4.8-5 ft), but other evidence suggests that the actual risk of scour is low. The channel is mixed bedrock and alluvial, with bedrock underneath the right abutment. The channel is moderately contracted and the approach flow is deep, two factors that greatly increase the live-bed amplification factor in the abutment scour equation, but do not necessarily increase scour, especially in a coarse-bedded, relatively low-gradient channel.

\section{North Fork Anchor River Bridge 1018}

Estimated abutment scour at North Fork Anchor River also is high, at $4.7-6.3 \mathrm{ft}$, although in this case it may be an underestimate. Hydraulic conditions (including a contracted bridge opening with vertical abutments and a sharp bend in the river approaching the bridge) are conducive to scour. A 5 -ft-deep scour hole was noted in a 2005 inspection at the right abutment toe, and inspection reports consistently note failure of the embankments and gabions placed to protect the abutments. A 90-degree bend in the channel approaching the bridge exposes the right abutment to increased hydraulic forces and flow separation unaccounted for in the one-dimensional model.

\section{Sawmill Creek Bridge 432}

Sawmill Creek Bridge 432 is located in a complicated setting. The bridge is highly skewed to the flow direction, reducing its capacity. The channel immediately upstream of the bridge has been extensively modified to accommodate a powerplant outfall. The 1- and 0.2-percent AEP floods and the largest flood on record in 2005 all reach the bridge superstructure. Estimated abutment scour ranges from 3.3 to $5.4 \mathrm{ft}$. Pier-scour estimates exceed $8 \mathrm{ft}$ for the complex piers with exposed footings; however, the footings are founded on bedrock $2.8 \mathrm{ft}$ below the current streambed so that pier scour is limited to $2.8 \mathrm{ft}$. Additionally, the left abutment is founded on bedrock, so only the channel to the right of the pier and the right abutment are subject to scour. A design engineer working on the powerplant observed aggradation of several feet following floods from tributary debris flows down the steep valley walls upstream (Dean Orbison, City of Sitka [retired], oral commun., August 27, 2015).

\section{South Fork Anchor River Bridge 1199}

The 0.2-percent AEP flood at South Fork Anchor River reaches the superstructure of the bridge and creates vertical contraction scour of $5.9 \mathrm{ft}$ and abutment scour of $7.3 \mathrm{ft}$. The 1-percent AEP flood is estimated to produce minor scour. The channel underneath Bridge 1199 was $2.5 \mathrm{ft}$ lower than the upstream cross section and $2 \mathrm{ft}$ lower than the downstream cross section during the field visit, indicating that contraction scour has occurred; thus, the 1-percent AEP flood estimate of $0.6 \mathrm{ft}$ probably is too low. This could be because live-bed or mixed conditions are present at lower flows rather than the clear-water conditions calculated. Live-bed scour for the 1-percent AEP flood was $5.5 \mathrm{ft}$ compared to $0.6 \mathrm{ft}$ for clear-water.

\section{Taiya River Bridge 309}

Taiya River Bridge 309 fills to the low chord at the check flood, and nearly so at the design flood. The 4.0-6.2 ft of contraction scour and 5.5-8.2 ft of abutment scour predicted for the 1967 flood and 1-percent AEP flows are reasonable given the contraction caused by the bridge and the historical elevation changes of $6 \mathrm{ft}$ in the channel bed noted in the sounding record. Taiya River is a relatively large river with a mobile bed.

\section{Victor Creek Bridge 607}

Pier scour at Victor Creek was calculated with the complex pier-scour equation and the coarse bed pier-scour equation. The complex pier-scour equation accounts for increased flow resistance caused by the exposure of the wide footing, but does not account for armoring. The coarse bed pier-scour equation accounts for armoring, and accounts for the width of the footing by using the full width of the footing as the pier width. Scour computed using the complex pier-scour equation was nearly $9 \mathrm{ft}$ (with contraction scour, 9.6-10.2 ft), whereas scour computed coarse bed pier-scour equation with a footing-width pier was $1.8-2.4 \mathrm{ft}$. Theresults from the complex pier-scour equation are considered conservative, especially given the transition to firmer soils around the footing noted in the as-builts, but the results from the coarse-bed pier-scour equation seem like an underestimate given the exposure of the footing. The channel at Bridge 607 has been degrading incrementally according to soundings, despite the very coarse bed sediment surrounding the pier, so the more conservative results are reported.

\section{West Creek Bridge 1490}

Total scour at West Creek Bridge 1490 piers ranges from 6.1 to $6.3 \mathrm{ft}$. There is a persistent debris accumulation, which increases estimated scour by about $2 \mathrm{ft}$, and little evidence of channel armoring. No scour holes have been noted in inspections or are present in the sounding record; however, live-bed scour is expected at this site and scour holes would fill in quickly. Bridge 1490 was not in place during the 1967 flood of record. 


\section{Summary and Conclusions}

Fifty-two bridge sites in Alaska were evaluated for streambed scour, including reach-scale stream stability, contraction scour, and local scour at piers and abutments. Most of the sites with unstable streambeds were on active alluvial fan landforms or were destabilized by in-stream mining. In these cases, reach-scale instability is not expected to increase contraction scour, although changing attack angles and aggradation may increase abutment scour, bank erosion, or approach road loss. One unstable site, Victor Creek Bridge 607, is entrenched in an inactive alluvial fan, and seems to be degrading slightly. Scour estimates are less reliable for unstable sites because the equations assume static channel geometry.

Design and check floods were determined for 52 sites that were modeled with HEC-RAS. The design floods used to calculate scour for most bridges were the estimated 1-percent AEP floods, but for two distributary sites where standard flood frequency techniques were not applicable, alternative design flood values (maximum pressure flow) were used to calculate conservative scour numbers. For two regulated streams, flood frequency estimation methods were adapted to the dam operation plans in place. Scour also was calculated for the 0.2-percent AEP flood at all but the two maximum pressure flow sites to show the effects of the check flood. Scour was calculated for large observed floods at 12 sites.

Contraction scour and abutment scour were calculated for all 52 bridges, and pier scour was calculated for the 11 bridges with piers. Vertical contraction occurred during the design flood or historical floods at four sites and during the check flood at eight sites, including the two distributary sites. Only four sites, all of which experienced vertical contraction, had estimated contraction scour of more than 5 feet (ft), and these only at the check flood. Sites with contraction scour concerns include Grouse Creek Bridge 1821, Little Susitna Braid Bridge 1713, South Fork Anchor River Bridge 1199, and Taiya River Bridge 309. Estimated total pier scour (pier scour plus contraction scour) exceeded $5 \mathrm{ft}$ at the design and check floods at four sites. In one case, Crescent Creek Bridge 1021, the pier-scour estimates appeared to be excessively conservative. Sites with the greatest pier-scour concerns include Alaganik Slough Bridge 395 (where scour holes have been noted in dive reports), Victor Creek Bridge 607 (where the footing has been exposed), and West Creek Bridge 1490.

Total scour at abutments exceeded $5 \mathrm{ft}$ during the design or historical floods at five sites, and during only the check flood at an additional five sites. Abutment scour is overestimated where embankment failure would widen channels, decreasing hydraulic forces on the abutment, and where low velocity and channel armoring would reduce the risk. Embankment erosion is common among study sites, with inspections noting it at 35 of the 52 sites. Riprap typically is used to protect abutments, but it is noted as missing or inadequate at 18 of the bridge sites.

\section{Acknowledgments}

The authors would like to thank Paul Schauer and Micah Claypoole (U.S. Geological Survey Alaska Science Center) for assisting with field data collection and analysis, Toby Feaster (U.S. Geological Survey South Atlantic Water Science Center) and Kenneth Wilson (U.S. Geological Survey Lower Mississippi-Gulf Water Science Center) for thorough peer reviews, and Janet Curran (U.S. Geological Survey Alaska Science Center) for assistance with flood frequency calculations.

\section{References Cited}

Arneson, L.A., Zevengergen, L.W., Lagasse, P.F., and Clopper, P.E., 2012, Evaluating scour at bridges (5th ed.): Federal Highway Administration Hydraulic Engineering Circular No. 18, Publication No. FHWA-HIF-12-003, 340 p.

Beebee, R.A., and Schauer, P.V., 2015, Streambed scour evaluations and conditions at selected bridge sites in Alaska, 2012: Scientific Investigations Report 2015-5154, 45 p., https://doi.org/10.3133/sir20155154.

Bergendahl, B.S., and Arneson, L.A., 2014, FHWA hydraulic toolbox, version 4.2: Federal Highway Administration, accessed February 4, 2015, at http:/www.fhwa.dot.gov/ engineering/hydraulics/software/toolbox404.cfm.

Brunner, G.W., 2016, HEC-RAS-River analysis system hydraulic reference manual, version 5.0, February 2016: Davis, Calif., U.S. Army Corps of Engineers Hydrologic Engineering Center, CDP-69, 539 p.

City and Borough of Sitka Electric Department, 2010, Application for capacity-related amendment, Blue Lake Hydroelectric Project (FERC No. 2230) Expansion: City and Borough of Sitka Electric Department, Volume 1, 65 p.

Chow, V.T., 1959, Open-channel hydraulics: New York, McGraw-Hill, p. 98-123.

Chugach Electric Association, 2005, Cooper Lake hydroelectric project, FERC No. 2170-Final license application, Exhibit A: Chugach Electric Association, 23 p.

Conaway, J.S., 2004, Summary and comparison of multiphase streambed scour analysis at selected bridge sites in Alaska: U.S. Geological Survey Scientific Investigations Report 2004-5066, 34 p.

Conaway, J.S., 2007, Analysis of real-time streambed scour data from bridges in Alaska-Proceedings of the 2007 World Environmental and Water Resources Congress, May 15-19, 2007, Tampa, Florida: American Society of Civil Engineers, 11 p. 
Conaway, J.S., and Schauer, P.V., 2012, Evaluation of streambed scour at bridges over tidal waterways in Alaska: U.S. Geological Survey Scientific Investigations Report 2012-5245, 38 p.

Curran, J.H., Barth, N.A., Veilleux, A.G., and Ourso, R.T., 2016, Estimating flood magnitude and frequency at gaged and ungaged sites on streams in Alaska and conterminous basins in Canada, based on data through water year 2012: U.S. Geological Survey Scientific Investigations Report 2016-5024, 47 p., https://doi.org/10.3133/sir20165024.

Ettema, R., Nakato, T., and Muste, M., 2010, Estimation of scour depth at bridge abutments: Washington, D.C., Transportation Research Board, NCHRP 24-20, 436 p.

Heinrichs, T.A., Kennedy, B.W., Langley, D.E., and Burrows, R.L., 2001, Methodology and estimates of scour at selected bridge sites in Alaska: U.S. Geological Survey Water-Resources Investigations Report 00-4151, 44 p.

Hicks, D.M., and Mason, P.D., 1998, Roughness characteristics of New Zealand rivers: Christchurch, New Zealand, National Institute of Water and Atmospheric Research, Ltd., 329 p.

Interagency Advisory Committee on Water Data, 1982, Guidelines for determining flood flow frequency: Hydrology Subcommittee Bulletin 17B, 28 p., 14 app., 1 pl.
Lagasse, P.F., Zevenbergen, L.W., Spitz, W.J., and Arneson, L.A., 2012, Stream stability at highway structures (4th ed.): Federal Highway Administration Hydraulic Engineering Circular No. 20, Publication No. FHWAHIF-12-004, 328 p.

Lamke, Robert D., 1972, Floods of the summer of 1971 in south-central Alaska: U.S. Geological Survey Water Resources Division Open-File Report 72-0215, Anchorage, Alaska, $88 \mathrm{p}$.

Norman, V.W., 1975, Scour at selected bridge sites in Alaska: U.S. Geological Survey Water-Resources Investigations Report 32-75, $160 \mathrm{p}$.

Shan, Haoyin, Xie, Zhaoding, Bojanowski, Cezary, Suaznabar, Oscar, Lottes, Steven, Shen, Jerry, and Kerenyi, Kornel, 2012, Submerged flow bridge scour under clear water conditions: Federal Highway Administration Publication No. FHWA-HRT-12-034. 43 p.

U.S. Geological Survey, 1993, Anchorage C-6 SE, Alaska: U.S. Geological Survey topographic map, scale 1:25,000.

Veilleux, A.G., Cohn, T.A., Flynn, K.M., Mason, R.R., and Hummel, P.R., 2013, Estimating magnitude and frequency of floods using the PeakFQ 7.0 program: U.S. Geological Survey Fact Sheet 2013-3108, 2 p., accessed February 5, 2015, at https://doi.org/10.3133/fs20133108. 



\section{Glossary}

\section{Annual Exceedance Probability (AEP)}

Flood Annual exceedance probability of a peak flow is the probability of that flow being equaled or exceeded in a 1-year period and is expressed as a decimal fraction less than 1.0. The recurrence interval of a peak flow is the number of years, on average, in which the specified flow is expected to be equaled or exceeded one time. Exceedance probability and recurrence interval are mathematically inverse of each other; thus, an exceedance probability of 0.01 is equivalent to a recurrence interval of 100 years.

Aggradation General and progressive buildup of the longitudinal profile of a channel bed resulting from sediment deposition.

Check Flood A theoretical flood larger than the design flood used by engineers to evaluate hydraulic conditions at a structure. For bridges over waterways, this usually is a 0.2-percent AEP flood (also known as a 500-year flood).
Design Flood A theoretical flood used by engineers to design a structure. Most bridges are designed to safely withstand the hydraulics created by a 1-percent AEP flood (also known as a 100-year flood).

Low Chord The lowest elevation of the superstructure of a bridge, usually the bottom of the girder supporting the deck or the lowest element of the deck if there is no girder. Also called "low steel.".

Superstructure The elements of a bridge, including deck, railing, and girder, that sit on top of the piers and abutments 



\section{Appendix 1. Stream Stability Cross Sections}

Repeat cross sections at each bridge as measured by Alaska Department of Transportation and Public Facilities and the U.S. Geological Survey are Microsoft ${ }^{\circledR}$ Excel files and are available for download at https://doi.org/10.3133/sir20175149. 

Publishing support provided by the U.S. Geological Survey

Science Publishing Network, Tacoma Publishing Service Center

For more information concerning the research in this report, contact the Director, Alaska Science Center

U.S. Geological Survey

4210 University Drive

Anchorage, Alaska 99508-4560

http://alaska.usgs.gov 
